\title{
Estados Alterados do Lugar
}

Tese apresentada ao Departamento de Artes Plásticas da Escola de Comunicação e Artes da Universidade de São Paulo, Área de Concentração Poéticas Visuais, como exigência parcial para obtenção de título de Doutor em Artes, sob orientação do Prof. Dr. Carlos Alberto Fajardo

\footnotetext{
Programa de Pós-Graduação em Artes Visuais

Escola de Comunicação e Artes

Universidade de São Paulo
} 
para minha mãe, Maria Celeste Machado, que me ensinou a pensar com desenhos de máquinas e cores. 


\section{Resumo:}

Esta Tese é composta de projetos de intervenção realizados no período de 2004 a 2008. Os trabalhos de arte apresentados aqui são alterações na arquitetura de espaços de museus, galerias ou centros culturais. A natureza destes trabalhos é de uma resposta a estes contextos por meio de transformações operadas em sua luz ambiente. O uso de anteparos semi-transparentes que denomino filtros, cria um sistema temporário de dispositivos e efeitos que afetam o lugar e seus frequentadores. Esta tese aborda a qualidade mimética desta intervenções observando a estratégia comum a elas e também suas especificidades táticas. Os trabalhos são apresentados como "máquinas de transformar" que criam estados alterados do lugar.

\section{Abstract:}

This Thesis is constitued by intervention projects made from 2004 to 2008. The artworks presented here are alterations made in architectural spaces at museums, galleries, cultural centers, etc. The nature of these works is to respond to those contexts operating transformations in their ambient light. By using partially transparent surfaces that I define as filters, a temporary system of devices and effects is created to affect the place and its users. This thesis approaches the mimetic condition of these artworks, observing the strategy they have in common and also their tactical specificities. The artworks are presented as "transformation machines" that create altered states of the place.

\section{Palavras-chave:}

arte na arquitetura

instalação

alterações temporárias

luz ambiente

condição mimética
Keywords:

art on architecture installation temporary alterations ambient light mimetic condition 


\section{AgRADECIMENTOS:}

Agradeço em primeiro lugar a Carlos A. Fajardo, meu orientador, por haver assegurado o foco nos trabalhos de arte realizados, acompanhando-os com observações e críticas sempre relevantes, e também por propor reflexões teóricas atentas as questões e conceitos operando ali, me indicando (e acompanhando) leituras fundamentais. O vínculo com sua orientação foi essencial para que esta tese fosse concluida;

a Mario Ramiro e Elaine Tedesco, artistas-amigos com quem compartilhei os problemas e soluções encontrados em nossas pesquisas de doutorado, pela generosidade e clareza;

a Marta Bogéa, Marco Donini, Beto Salvi e Tuti Giorgi, arquitetosamigos, pelas inúmeras consultas informais, me dando elementos para a "tradução" de conceitos do campo da arte para a arquitetura e vice-versa;

a Everton Ballardin, Marcelo Zocchio, Fabio Del Re, e Leticia Ramos, pelas imagens de trabalhos;

a Letissa Kanawati e Carlota Mazon, assistentes e colaboradoras indispensáveis;

a Arlette Mabilde, por sua supervisão no campo da matemática;

a Marcos Chaves e Luiza Mello, sempre comigo;

a Luciana Azanha e Carlos Christofani, que me ajudaram a encontrar espaço nesta cidade, donos de afetos da melhor espécie;

e a Rodrigo Bivar, pela presença constante e por sua leitura sensível e crítica. 


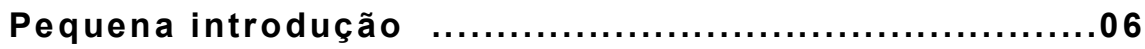

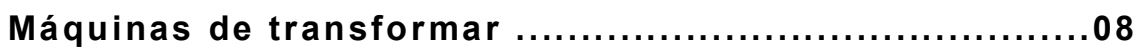

Mimetis mo como estratégia................................15

A "tentação do espaço" ..................................15

Poder de afetar, poder de ser afetado $\ldots \ldots \ldots \ldots \ldots \ldots 17$

Arte construtora, arte ambientada .....................24

Matemática aplicada........................................... 30

Matemática Espontânea.................................35

Dein Spiegel............................................. 40

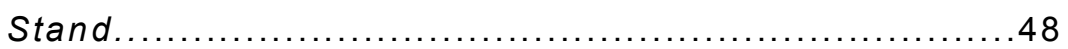

Proximidade, colaborações e outros atritos................54

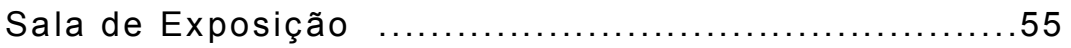

Un Buen Orden (com Hector Zamora)...................57

Parede-favo (com Jarbas Lopes).......................59

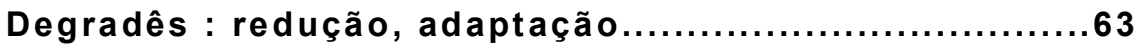

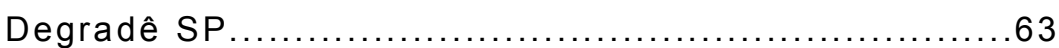

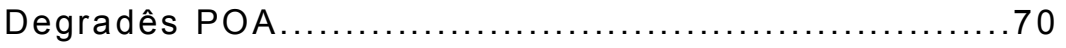

Filtro : cinema sem filme................................... 74

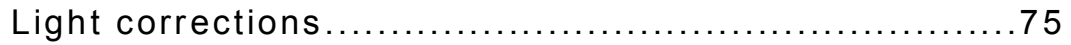

Correções de Luz.......................................... 85

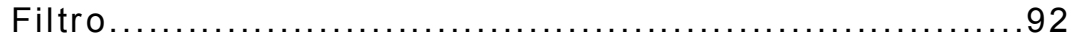

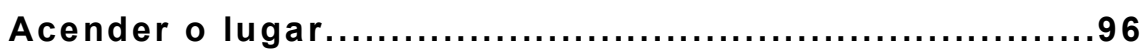

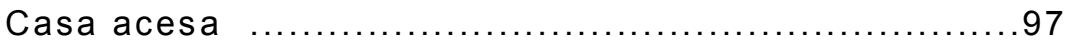

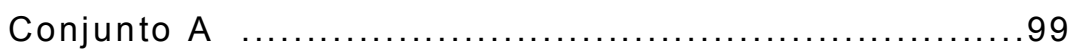

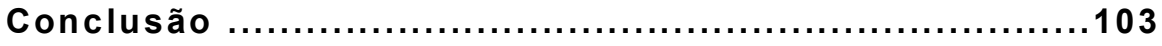

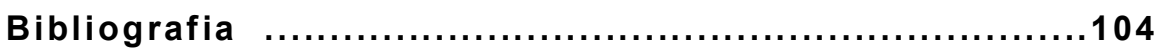




\section{Pequena introdução}

Esta pesquisa foi feita na ação sobre espaços, é um conjunto de alterações sensíveis produzidas na luz ambiente de espaços de exibição de arte e seu entorno. Os trabalhos realizados são "estados alterados do lugar", esta é sua proposição. Aconteceram em locais muito diversos, sempre respondendo a linguagem da arquitetura com dispositivos ou raciocínios familiares aos contextos, mas articulados de modo sensivelmente novo ali onde se colocavam.

A pesquisa em arte circunscreve um objeto e um campo conceitual que se constróem em uma linguagem usualmente não-verbal e muitas vezes não-representativa. O problema que se coloca ao artista quando faz pesquisas desta natureza, em que o campo de sua ação coincide com o campo da reflexão, é produzir um discurso de outra natureza e que reuna aquilo que não está acessível na fruição de seu trabalho. Um texto que seja atento a experiência direta com o trabalho, que ao mesmo tempo tenha uma forma autônoma capaz de atrair para suas próprias questões.

Os primeiros textos tratam de conceitos e operações observados nos trabalhos, mas trazidos para um terreno mais teórico, das leituras feitas, das investigações e desvios do pensamento. As escolhas conceituais são explicitadas antes da apresentação dos trabalhos. As definições de lugar e espaço para encontrar o que é modificado nas ações praticadas. O mimetismo como uma transformação que se funde estrategicamente ao lugar, para entender trabalhos de arte miméticos que buscam com uma certa invisibilidade, afetar globalmente a experiência do sujeito. E a idéia de que o poder de afetar implica em provocar ações e pensamentos em vários níveis: sensação, especulação, imaginação, formulação. 
Quando saimos do terreno do que é constante nos trabalhos para o que eles tem de específico a cada lugar ocupado, entramos em textos em que a sua dimensão concreta, como projeto ou acontecimento, é acompanhada das imagens que documentam os "estados alterados" e, em alguns casos, os lugares antes deles. É claro que esta documentação é insuficiente para nos dar a saber da experiência em si, e uma das funções do texto é justamente enriquecer esta documentação com observações e memórias subjetivas. Em alguns casos intersubjetivas, em comentários do público que foram registrados e incluidos aqui. Sempre investigando a repercussão dos trabalhos, as especulações sobre os efeitos e suas causas.

Acompanha este texto ilustrado um conjunto de imagens digitais mais completo - incluindo videos e extensas documentações que não caberiam neste formato - exibido em um CD de conteúdo "navegável". No esquema pelo qual se acessam as imagens, os trabalhos estão organizados em subconjuntos que correspondem a sua ordem neste texto. Penso que estas imagens devem ser "navegadas" antes de se começar a ler o texto, para causar uma impressão viva e não excessivamente mediada dos trabalhos que se mantenha presente até o final da leitura.

Uma vez que os trabalhos são entendidos como acontecimentos, o recorte foi temporal: os trabalhos que apresento como corpo da tese foram realizados entre 2004 e 2008. Muitos trabalhos feitos neste período foram excluídos para que aqueles expostos aqui tivessem o espaço de reflexão adequado. Eventualmente aparecem no texto referências a trabalhos anteriores, nos momentos em que achei essenciais a compreensão do raciocinio operando agora, de suas origens. 


\section{MÁQUINA DE TRANSFORMAR}

Se o lugar está sujeito a estados alterados é porque se configura e comporta como um organismo de estrutura complexa e que reage a seu contexto em constantes adaptações a necessidades sempre singulares. Toda intervenção nele é feita no tempo, num momento específico de seu ciclo vital. Assim como as alterações que inevitavelmente ocorrem estando ele ocupado ou abandonado, exposto ao tempo e a ação dos que o habitam.

Mas o conceito de lugar-organismo excluiria a idéia de uma construção nos termos da arquitetura ou da arte? Podemos falar do lugar como algo projetado e construído, como uma espécie de máquina como definia Le Corbusier em suas proposições de máquinas de morar? Ou este seria o espaço?

Usamos aqui o conceito de espaço como "lugar praticado" como propõe Michel de Certeau em "A Invenção do Cotidiano"1. O lugar abriga os sucessivos estados e conformações produzidos pelo uso do espaço e esta produção informa e reorganiza a dinâmica deste. O espaço não é mero continente mas a dimensão concreta de um campo de relações possíveis e realizadas, o efeito das práticas sociais. Se o lugar é, como afirma Certeau, "uma configuração instantânea de posições", está indicada nesta instantaneidade, não apenas uma ordem estável mas a sua impermanência. O lugar é uma ordem que guarda e expõe sua própria instabilidade e confusão, suas distorções estão inscritas ali e são manifestas em desvios ou alterações de intensidade efetuadas no espaço.

Se a arquitetura que habitamos hoje não se pensa mais como máquina moderna, quando nela se integram novos dispositivos e seus efeitos,

\footnotetext{
${ }^{1}$ CERTEAU, Michel de. A Invenção do Cotidiano - Artes de Fazer. Petrópolis: Ed. Vozes, 1994. (pág,201)
} 
reaparece esta condição de máquina que faz algo acontecer? É um novo espaço que se instaura ali, no lugar alterado?

Os trabalhos de arte que constituem esta pesquisa e são apresentados nesta tese, respondem a linguagem da arquitetura, moderna ou não, operando com dispositivos que procuram converter o espaço em "máquina de transformar", com alterações em sua luz ambiente, em sua ordem sensível (nem sempre evidente), para provocar transformações no lugar e nos sujeitos que o frequentam.

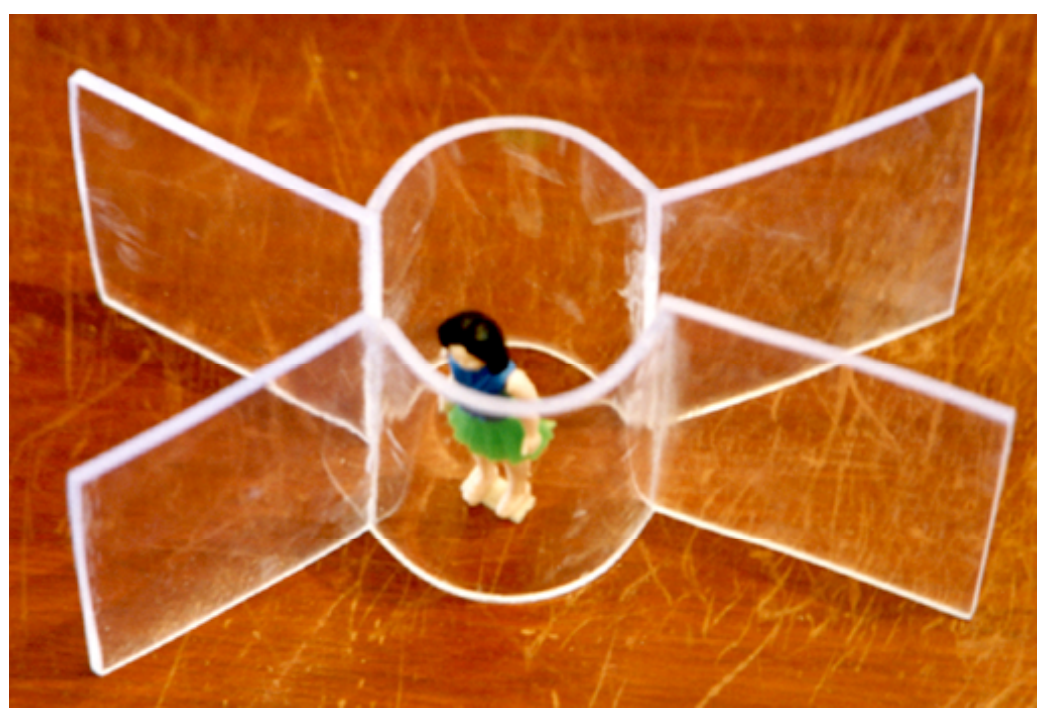

maquete do projeto "Máquina de transformar", 1999

"Máquina de transformar" é também o título de um projeto concebido em 1999 mas nunca realizado, que pode ilustrar, por sua natureza esquemática, algumas das questões mais importantes operando nestes trabalhos. Seu partido é o de um diagrama tridimensional e transparente. O conceito de máquina neste caso vem da linguagem da matemática moderna e não do repertório da arquitetura moderna, embora se possa encontrar em Le Corbusier (1928) esta associação entre máquina e transformação, vivida na época como inevitavelmente perturbadora: "a sociedade moderna está em plena transformação, tudo é transtornado pela máquina." 2 Acreditava que a questão da casa

\footnotetext{
${ }^{2}$ LE CORBUSIER . Por uma Arquitetura. São Paulo: Ed. Perspectiva (Col.Estudos) 2002 in Temperatura, (pág XXVII)
} 
não estava posta em termos do sentido que tinha em seu tempo, para o homem moderno que buscava (re)definir, daí sua proposição da casa como "uma máquina de morar". A idéia de máquinas de morar ou de emocionar de Le Corbusier eram fundamentais para recolocar os modos de conceber e habitar espaços, reinventando-os com a perspectiva de novos usos e de uma escala humana, não monumental.

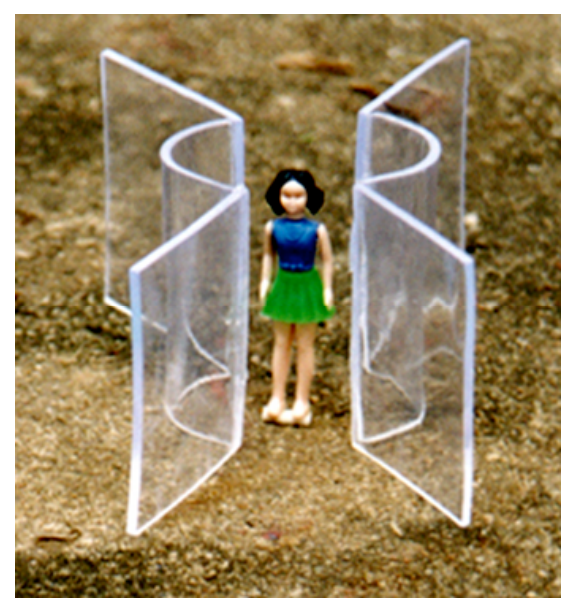

No campo do ensino da matemática moderna, a noção de máquina é usada num esquema didático que introduz o conceito de operação com números, um diagrama aberto para representar qualquer operação, com uma entrada, uma saída e uma área central onde esta se dá. A cada uso, se definem elementos e se atribui uma operação. Por exemplo, se formos multiplicar por 3 um numero qualquer, podemos imaginar - e no caso deste esquema gráfico, desenhamos - que "entram 2 caixas", "em cada caixa colocamos 3 bolas", "quantas bolas saem da máquina?" Representando uma situação concreta através da aplicação de esquemas universais, a matemática moderna acaba por criar um campo onde imaginar é atividade essencial : o diagrama vazio não opera nada. Imaginar torna específico e dá dimensão real aos conceitos, é instrumental para a apropriação destes.

Muitas das atividades didáticas propostas pela matemática moderna envolvendo os esquemas chamados "máquinas" tem escala ampliada no espaço tridimensional, os diagramas são desenhados no piso e neles cabem seus "operadores", usualmente crianças que interagem 
com os objetos no espaço desenhado. Tem portanto a escala do corpo do sujeito, é com ele e suas ações que aprende a operar. A partir da experiência desta escala, e da projeção deste desenho - linhas tornadas paredes - esta máquina de transformar foi pensada. Um diagrama tridimensional construído em acrílico (aberto e transparente, entrada e saída idênticas, duplamente simétrico), que pode operar infinitas transformações imaginadas pelos sujeitos que o atravessam.

Por que, e principalmente, como, a máquina de transformar deve ser transparente? Que espécie de transparência? O essencial é que a estrutura do mecanismo esteja completamente exposta para que se possa usar esta máquina, que sua entrada e sua saída sejam simultâneas e visíveis de dentro e de fora dela. Que esteja dada claramente a estrutura básica permanente e neutra para que os operadores possam atribuir ações especificas a cada uso. Que o sujeito que opera e o sujeito que assiste possam saber um do outro, ver-se através dela.

Para Colin Rowe, autor do texto "Transparency: Literal and Phenomenal" carregada com as possibilidades tanto da significação quanto da incompreensão". Rowe e Robert Slutzky, co-autor deste ensaio, definem dois tipos de transparência na arquitetura: uma que seria literal, das matérias empregadas em construções, e outra que se refere a experiência de simultaneidade de espaços na percepção do observador.

Os autores citam a definição de figuras transparentes de Gyorgy Kepes, artista e pesquisador da teoria da percepção: “(...) são capazes de interpenetrar-se sem a sua destruição óptica. No entanto, a transparência implica em mais do que uma característica óptica, ela

\footnotetext{
3 ROWE, Colin. "Transparency: Literal and Phenomenal. "In Architecture Culture" 1943-1968, A Documentary Anthology. Joan Ockman, editor. New York: Rizzoli, 1993.
} 
implica em uma ordem espacial mais ampla. Transparência significa a percepção simultânea de distintas localizações espaciais. O espaço não apenas recua mas oscila em constante atividade." ${ }^{4}$

É esta transparência que Kepes descreve como um dado perceptivo, numa abordagem fenomenológica, que Rowe e Slutzky reconhecem em Le Corbusier e no cubismo. Não é a mesma transparência dos materiais que eles chamam de literal e que identificam na arquitetura da Bauhaus e na arte dos construtivistas russos. Suas análise de obras de arte e arquitetura são pertinentes justamente porque observam (em alguns casos, de projetos nunca executados, apenas imaginam) a experiência perceptiva de obras específicas num campo e noutro, e os conceitos subjacentes. Usam a leitura do que é próprio do espaço na arquitetura como referência para rever o espaço na arte e vice-versa. O modo de abordar a relação entre os dois campos, a partir da observação de fatos arquitetônicos e artísticos que exploram espacialidades semelhantes, é talvez a maior contribuicão deste texto em minha pesquisa. E a compreensão de que mesmo quando empregamos materiais transparentes, é a transparência como fenômeno que mobiliza o observador em sua experiência com o lugar, tornando-o capaz de agir sobre ele.

Em "The Architectural Uncanny", Anthony Vidler atualiza a leitura da transparência na arquitetura e sua dimensão política, e procura resgatar a necessidade dos espaços escuros e assombrados em oposição a excessiva transparência da arquitetura modernista, apontada como instrumento da idéia de visibilidade e (consequentemente) controle totais. A condição moderna do unhomely - e do inabitável - seria o correspondente espacial do uncanny, conceito que Vidler associa ao unheimlich usado por Sigmund Freud

\footnotetext{
${ }^{4}$ Kepes, Gyorgy, Language of Vision, Chicago, 1944, p.77

${ }^{5}$ VIDLER, Antony. The Architectural Uncanny - essays in the modern unhomely. Massachusetts: MIT Press, 1992.
} 
em texto publicado em $1919^{6}$, no qual faz uma rara incursão no campo da Estética ${ }^{7}$. Freud trata da formação do termo unheimlich no alemão, em oposição ao familiar, e conhecido: "Chama-se unheimlich tudo o que deveria permanecer secreto, escondido, e se manifesta". O uncanny (tradução de unheimlich para o inglês) na teoria psicanalítica de Freud supõe algo que era familiar e foi transformado em estranho por um processo de recalque na infância. Quando aborda estes conceitos, Vidler aponta a ligação inevitável entre estranhamento e familiaridade, operando nas situações em que os espaços conhecidos se encontram visivelmente alterados.

É neste campo do estranhamente familiar (algo da natureza do lugar que se encontra "rebaixado" em seu estado atual, reanimado pelas intervenções), da transparência relativa, dos sinais de ocupacão e adaptação dos espaços a novos usos, das alterações temporárias que podem ou não deixar vestígios no lugar, que investigo operações possíveis nos locais que habito com meu trabalho.

\footnotetext{
${ }^{6}$ A versão traduzida para o inglês usada pela autora encontrada em $\mathrm{http}: / / \mathrm{www}-$ rohan.sdsu.edu/ amtower/uncanny.html

7 “É raro que um psicanalista se sinta impelido a investigar o tema da Estética, mesmo quando a Estética é entendida não meramente como a teoria da beleza, mas a teoria das qualidades do sentir." (tradução da autora)
} 
Mimetismo como Estratégia - dispositivo integrado ao lugar

"Tentação do espaço", é uma expressão usada por Roger Caillois em "Mimetismo e Psicastenia Legendária"8, tratando do fenômeno do mimetismo animal (homocromia, homomorfismo, etc.), descrito como uma pulsão de semelhança do organismo com o meio. Segundo Caillois, o que habitualmente acreditamos ter nas espécies miméticas a função de um mecanismo de proteção contra seus predadores, é na verdade um estado alterado gerado pelo fascínio por seu entorno, que faz com que os organismos reproduzam sua aparência, fundindo-se a ele. Caillois trata esta pulsão como análoga à patologia da despersonalização do sujeito por assimilação ao meio, analogia que atraiu leitores como Lacan e Walter Benjamim. Deslocando este princípio para o campo dos trabalhos de arte derivados de um dado contexto, o mimetismo pode indicar uma opção pela dissolução do limite entre obra e entorno, substituindo o objeto pelo acontecimento. E a imitação operada pelo animal mimético pode ser comparada ao uso da linguagem arquitetônica para responder a um ambiente construído.

No âmbito do mimetismo animal, a pele é o órgão sensível que "vê" e reage ao entorno. Esta resposta natural e artificiosa, se dá numa superfície de contato entre corpo e meio, limite entre interno e externo, onde estes se tocam. É na pele que acontecem as modificações de cor e forma características do mimetismo. Ela é sensível ao que a cerca e recebe e reproduz informação, como se fosse uma câmera de vídeo que captura e exibe instantaneamente, ponto a ponto, o que percebe. Está equipada para sentir as diferenças cromáticas ainda que não as traduza em imagem para si, uma vez que não está conectada ao nervo óptico que é essencial à visão. Mas converte-se em imagem ela mesma.

${ }^{8}$ CAILLOIS, Roger. Mimetismo e Psicastenia legendária, revista CHE VOUI, ano1, nº 0, 1986, p. 49-73. 
A conceito de pele como dispositivo é também corrente no vocabulário da arquitetura, e parece adequado para designar os filtros que aplico nas aberturas dos espaços que ocupo. Na linguagem da arquitetura, que aqui também desloca conceitos de outros campos, a "pele" é superfície de partilha, tem função de vedo e é pensada como membrana que define o espaço. É um dispositivo de comunicação entre dentro e fora, que reveste e é permeável a luz e ao olhar. Respira. Por isso é um termo tão adequado para definir os elementos que acrescento aos lugares: são novas peles postas ali que parecem alterações da pele original ou anterior.

O mecanismo mimético nos animais produz efeitos semelhantes ao de um espelho pois os cromatófaros, as células elásticas em sua pele que contém pigmentos e se alteram por estímulos visuais, replicam cor e luminosidade para produzir as homocromias variáveis. Tudo se dá no campo da visualidade, tanto o efeito para o observador (predador? presa?) quanto o processo que o causa no organismo: estas mudanças são reações ao meio que podem ser vistas como estados alterados produzidos por controle neurohormonal respondendo a luz e temperatura ambiente percebidas. O dispositivopele é como um espelho pois reproduz em si a imagem do entorno criando provisoriamente outra aparência e fundindo-se neste. Inserido na arquitetura, o espelho multiplica espaços e cria transparências virtuais que se transformam com o deslocamento do ponto de vista ou as mudanças na luz, portanto também temporárias. E porque ele processa dados presentes e visíveis, a simultaneidade do entorno e sua imagem cria continuidade entre espelho e aquilo que ele reproduz. Tanto mais efetivamente mimético quanto menos for percebida a presença do dispositivo, seus contornos desaparecendo e confundindo espaços real e virtual.

Esta confusão visual é desejável pois pode conduzir a uma desorientação, que obrigue a uma reorientação. Este é o sentido de transformação proposto aqui. 
Quando o que é posto ali se funde ao que já existia, desaparece como coisa porque não faz sentido sozinho, mesmo estando necessariamente no terreno do visível. Não tem autonomia de objeto. A invisibilidade das partes em favor de uma transformação temporária do todo, é intencional e pode ter vários graus, de quase imperceptível até afetar completamente a existência do lugar. Se a perturbação provocada é visivelmente associada ao dispositivo que a gerou, o sujeito pode especular em termos das outras alterações praticáveis, imaginando os efeitos possíveis ali e em outros ambientes conhecidos.

O lugar afeta e é afetado pelo elemento que nele se mimetiza pois esta alteração, mesmo temporária intensifica os aspectos mais característicos de sua aparência, cria continuidade onde poderia haver diferença, dissolve contrastes. E na experiência do sujeito que o frequenta se produzem ressonâncias que a estendem para além da sua duração. 


\title{
Poder de afetar, poder de ser afetado
}

\begin{abstract}
"Por afeto compreendo as afecções do corpo, pelas quais sua potência de agir é aumentada ou diminuída, estimulada ou refreada, e ao mesmo tempo, as idéias destas afecções."
\end{abstract}

Benedictus de Spinoza ${ }^{9}$

Se o trabalho instaura algo que é de certa forma familiar onde poderia ser estranho, é porque produz um novo estado das mesmas coisas e não coisas novas. Faz isto por via de estratégia mimética, assemelhando-se a lógica do lugar, conformando-se a ela de tal modo, que sugere tanto sua própria existência anterior, como futura. Isto se revela em depoimentos de sujeitos que fruem estas alterações, quando manifestam o desejo de que permaneçam ("isto deveria ficar aqui pra sempre"), ou assumem que aquele elemento já fazia parte do lugar ("pensei que fazia parte daqui!"), era anterior a proposição de um artista. São idéias que respondem imediatamente a experiência no lugar temporariamente transformado, indicando que o sujeito foi afetado por ela e que projeta outras possíveis afecções a partir dos efeitos ali criados no caso de serem transportados, retomados em outro local ou em outra ocasião. O desejo de permanência pode significar que, uma vez tornado parte do lugar, o trabalho quando destruído seria uma parte do lugar desaparecendo. A subtração dele se tornaria assim mais visível que sua implantação no espaço. A falta e o desejo subsequente são posteriores ao trabalho e não geradores dele como se costuma supor a respeito dos trabalhos de arte. Em muitos casos também se ouvem comentários como : "eu faria isso na entrada de minha casa" ou "na janela do meu quarto o efeito seria assim". Isto poderia ser causado pelo que Spinoza chama de afeto da alegria, que provoca "um aumento da potência de agir" no sujeito.

A leitura dos textos de Benedictus de Spinoza (1632-1677) sobre a natureza das idéias e dos afetos (segunda e terceira partes de sua

\footnotetext{
${ }^{9}$ SPINOZA, Benedictus de. Ética. Belo Horizonte: Ed. Autêntica, 2008.Terceira parte: a origem e natureza dos afetos (pág.163)
} 
"Ética"), onde trata também das noções de duração e existência, alimentou uma reflexão sobre o caráter impermanente e um certo grau de invisibilidade próprios ao conjunto de trabalhos apresentados aqui.

"Finalmente por perfeição em geral compreenderei, como disse, a realidade, isto é, a essência de uma coisa qualquer, enquanto existe e opera de uma maneira definida, sem qualquer relação com sua duração. Com efeito, de nenhuma coisa singular se pode dizer que é mais perfeita por perseverar mais tempo no existir. Pois a duração das coisas não pode ser determinada por sua essência, porque a essência das coisas não envolve qualquer tempo definido e determinado de existência. Uma coisa qualquer, entretanto, seja ela mais perfeita ou menos perfeita, sempre poderá perserverar no existir com a mesma força com que começa a existir." 10

Quando se manifesta na fala do público a idéia de que o lugar transformado "ficou melhor assim", é formulado um pensamento crítico para além da simples afecção, sugerindo que o trabalho produz algo com maior "perfeição" - e portanto mais real, segundo Spinoza - que o espaço sem ele. Este juízo de valor não implica numa avaliação de ordem estética, mas no grau de realidade observado em sua experiência e o acesso a essência de uma coisa que ele possibilita.

A distinção entre idéia (modo de pensamento representativo) e afeto (modo de pensamento não-representativo), assim como a correspondência entre as noções "poder de ser afetado" e "potência de agir", são as principais razões do interesse desta pesquisa, na obra de Spinoza. Seu conceito de idéia-affecção como um tipo de idéia imediata e precária parece essencial para entender que os efeitos causados por estes trabalhos não são exclusivamente sensoriais ou físicos, mas já uma espécie de pensamento, que é também gerador de afetos e que demanda pensamentos de outra natureza, mais intencionais, claros e adequados. Se o sujeito é afetado pela presença do trabalho, ou seja, pelo estado alterado do lugar, é natural que a esta afecção se sigam outros pensamentos que o coloquem em ação. O sujeito é sempre autor de uma ação derivada

\footnotetext{
${ }^{10}$ SPINOZA, Benedictus de. Ética. Belo Horizonte: Ed. Autêntica, 2008.Quarta parte: a servidão humana e a força dos afetos (pág.267)
} 
de sua experiência, e a primeira delas é a imaginação. "A mente esforça-se, tanto quanto pode por imaginar coisas que aumentam ou estimulam a potência de agir do corpo."11

Quando Spinoza busca compreender e definir a natureza dos afetos, se dedica a observar os efeitos das coisas e das idéias, operando num campo conceitual comum ao pensamento da arte atual, uma vez que a origem ou idéia inicial do trabalho de arte é hoje menos relevante para sua leitura e fruição, que sua repercussão, seus modos de operar e sua inserção no mundo real.

Gilles Deleuze aborda o pensamento de Spinoza em um de seus seminários acerca da noção de "variação contínua"12, em 1978. Sua leitura propõe que Spinoza define os afetos como "variações", "flutuações de ânimo" geradas por idéias que representam a realidade e que podem assumir a condição de realidades em si mesmas. Deleuze afirma que "o affectus em Spinoza é a variação (é ele quem fala pela minha boca; ele não chegou a dizê-lo porque morreu jovem demais...), é a variação contínua da força de existir na medida em que essa variação é determinada pelas idéias que se tem.(...) o afeto é constituído pela transição vivida ou pela passagem vivida de um grau de perfeição a outro, na medida em que essa passagem é determinada pelas idéias; porém em si mesmo ele não consiste em uma idéia, ele constitui o afeto". O conceito de afecção (do latim, affectio) é distinto do de afeto: "Spinoza dirá que uma affectio indica mais a natureza do corpo modificado do que a natureza do corpo modificante, e que ela envolve a natureza do corpo modificante". O que no texto de Spinoza é definido como "corpo externo" em Deleuze aparece como corpo modificante, implicando diretamente na idéia de um corpo modificado. A ênfase na modificação e na relação de interdependência dos corpos

\footnotetext{
${ }^{11}$ SPINOZA, Benedictus de. Ética. Belo Horizonte: Ed. Autêntica, 2008.Terceira parte: a origem e natureza dos afetos. Proposição 12. (pág.179)

12 http://www.webdeleuze.com/php/texte.php?cle=194\&groupe=Spinoza\&langue $=5$
} 
envolvidos é coerente com o pensamento de Spinoza e também o atualiza de certa forma. E se pensamos sobre os trabalhos apresentados aqui como corpos modificadores, entendemos a enorme influência que tem o corpo modificado do lugar, tanto no corpo do trabalho quanto na experiência do sujeito que o vê alterado.

Ainda Deleuze: " (...) cada coisa, corpo ou alma, se define por uma certa relação característica, complexa, mas eu também poderia dizer que cada coisa, corpo ou alma, se define por um certo poder de ser afetado. Se vocês considerarem os animais, Spinoza nos dirá com muita força que aquilo que importa nos animais não são os gêneros e as espécies; os gêneros e as espécies são noções absolutamente confusas, são idéias abstratas. O que importa é: de que um corpo é capaz?"13

Spinoza sugere também, na proposição 39 da "Segunda Parte - a natureza e a origem da mente" - de sua "Ética", que os corpos afetados tem algo de próprio em comum com os corpos externos. Esta identificação precedente entre corpos modificado e modificante nos reenvia a condição mimética como pulsão de identificação do organismo com seu meio, observada por Caillois. E indica que o organismo parte de algo em comum entre a sua natureza e a natureza do entorno.

No caso destes trabalhos na arquitetura o entorno é de certa forma sempre novo, e aquilo que se produziu como resposta a um contexto não pode ser completamente transferido a outro sem perda de sentido. Como produzir conhecimento se eu não posso via de regra fazer generalizações? Como definir uma estratégia se ela só é possível, como nos diz Michel de Certeau, "a partir do momento em que um sujeito de poder e querer é isolável de um ambiente"? Este isolamento não é possível ou desejável no campo dos trabalhos desta pesquisa.

13 http://www.webdeleuze.com/php/texte.php?cle=194\&groupe=Spinoza\&langue $=5$ 
Cada projeto atualiza repertórios de procedimentos e conceitos a cada ação, mas só pode gerar sentido com isto se o fizer a partir de sua experiência com o lugar, de uma situação encontrada.

Tática e Estratégia como lógicas da ação são categorias definidas por Michel de Certeau (1980), que se referem a prática do espaço e a maneira de frequentar um lugar, respectivamente. O espaço geométrico, arquitetônico, se define estrategicamente, constituindo um lugar a ser habitado por certos sujeitos e ações, enquanto o espaço topológico, existencial, é definido pela experiência espacial, nas táticas sempre parciais de resposta ao outro imediato, sem a perspectiva de uma totalidade. "A tática só tem por lugar o do outro. (...) a tática depende do tempo, vigiando para 'captar no vôo' possibilidades de ganho. E o que ela ganha, não o guarda. Tem constantemente que jogar com os acontecimentos para os transformar em "ocasiões". 14

Nestes trabalhos que respondem a arquitetura com sua própria linguagem, a estratégia é mimética e a tática varia com as circunstâncias específicas de cada lugar. Se o mimetismo é o que identifica todos os trabalhos, cada um deles é concebido a partir de um contexto sempre diferente. A imitação como tática aparece no conto "A carta roubada" 15 de Edgar Allan Poe, lido por Jacques Lacan em seu texto sobre o "estádio do espelho" 16 .

\footnotetext{
${ }^{14}$ CERTEAU, Michel de . "A invenção do cotidiano: 1. Artes de fazer". (9 $9^{\mathrm{a}}$ ed.) Petrópolis, RJ: Vozes, 1994.(pág.46)

15 POE, Edgar Allan. "A Carta Roubada” In Os Assassinatos da Rua Morgue. A Carta Roubada. (2a ed.) São Paulo: Paz e Terra, 1997.

16 LACAN, Jacques. "O estádio do espelho como formador da função do eu". In: Escritos. Rio de Janeiro: Jorge Zahar, 1998. O texto final do estádio do espelho é apresentado em sua versão definitiva em 17 de julho de 1949, no XVI Congresso Internacional de Psicanálise, em Zurique, com o nome de: "O estádio do espelho como formador da função do eu - tal como nos é revelada na experiência psicanalítica".
} 
O conceito do estádio do espelho foi desenvolvido por Lacan a partir da experiência de Henry Wallon ${ }^{17}$ que, em 1931, descreveu como a criança vai aos poucos diferenciando seu corpo da imagem que observa no espelho. Segundo Wallon, isto se daria face a uma compreensão simbólica, por parte do sujeito, do espaço imaginário em que constitui sua unidade corporal. A "Prova do espelho", como Wallon chamou sua experiência, demonstraria, assim, a passagem do especular para o imaginário e do imaginário para o simbólico. A função estruturadora do espelho está no fato de que para a criança reconhecer ali, a presença do outro e de sua imagem é essencial, e a experiência com sua imagem Ihe dá alguma exterioridade.

No caso dos espelhos recortados usados como filtro, eles misturam espelho e não-espelho na superfície descontínua, assim como misturam dentro e fora, aqui e ali. Espacialmente não são muito esclarecedores. Se estruturam nossa compreensão de um espaço de simultaneidades, o fazem porque a imagem do sujeito que vê aparece recortada ali. Neste caso há uma inversão: é sua imagem refletida que Ihe dá a ver/reconhecer o espaço exterior a ele. Os sujeitos que viveram experiências anteriores com o dispositivo espelho conhecem seu funcionamento o bastante para serem capazes de identificar suas disfunções usando-as justamente para ler o entorno, ali refletido e fragmentado.

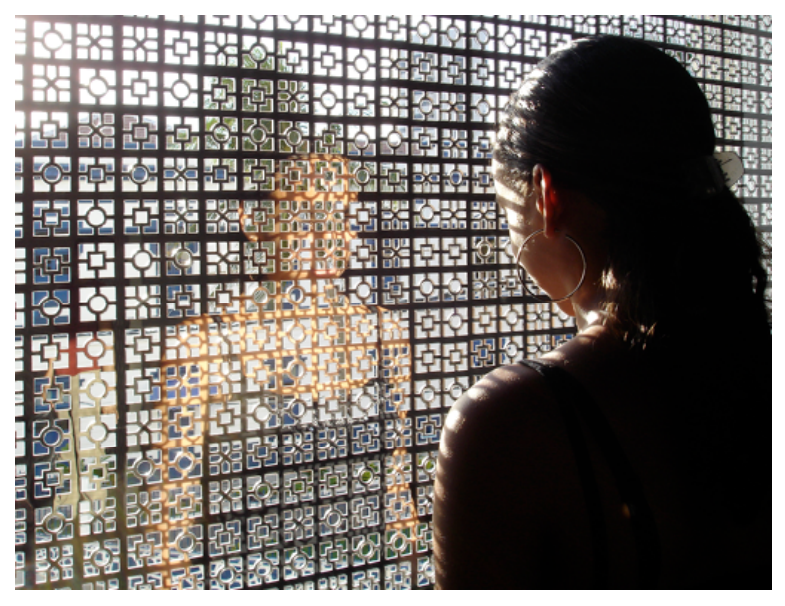

“Matemática Espontânea”, 2006

\footnotetext{
${ }^{17}$ Henri Wallon (1879/1962), foi um filósofo marxista e médico, pesquisador da psicologia do desenvolvimento na infância, muito influente para autores como Lacan e Piaget.
} 
Mas voltando a função da imitação no conto de Poe, quando interrogado sobre como fazia para vencer sempre num jogo de cartas, o menino diz imitar as expressões de seu oponente para adivinhar-Ihe a intenção e o pensamento, usando o espelhamento como modo de comunicação direta entre dois sujeitos, ou "identificação do intelecto" do outro, como diz outro personagem. A intersubjetividade é o motor das táticas no espaço, pois o outro me permite enfrentar uma certa complexidade porque sua presença e o que o distingue de mim, me ajudam a entender o lugar e as relações entre sujeitos e espaço das quais faço parte. O fato de que sou afetado necessariamente pelo outro, ao mesmo tempo que sou afetado pelo lugar, é simétrico ao fato de que os espaços são constituídos das relações ali estabelecidas e portanto também afetados por mim e pelo outro em ação.

No caso das intervenções miméticas, quando se imita o lugar acrescentando elementos que se assemelham a ele em raciocínio e natureza e replicando sua configuração e raciocínio, isto é feito estrategicamente. Mudando as condições de sua percepção e integrando-se ali, estes trabalhos acabam por fundir-se e a fusão desierarquiza tudo. Nada é anterior ou posterior, tudo pura simultaneidade: o trabalho pertence ao lugar e o lugar lhe pertence. 


\section{Arte Construtora, arte ambientada.}

Ainda sobre as misturas de corpo modificante e modificado, Deleuze fala do uso em Spinoza do conceito de encontro (do latim "occursus"): "Spinoza diz que o mal, o mal é um mau encontro. Encontrar um corpo que se mistura mal com o seu. Misturar-se mal quer dizer misturar-se em condições tais que uma das suas relações subordinadas ou sua relação constituinte é ameaçada, comprometida ou mesmo destruída. (...) Quando eu faço um encontro de modo que a relação do corpo que me modifica, que age sobre mim, combina-se com minha própria relação, com a relação característica do meu próprio corpo, o que é que acontece? Eu diria que minha potência de agir é aumentada; ela é aumentada ao menos sob aquela relação". ${ }^{18}$

Bons encontros, misturas que aumentam nossa potência de agir, podem acontecer voluntariamente. Em 1993, eu e outros 7 artistas brasileiros criamos um projeto coletivo chamado Arte Construtora ${ }^{19}$. Naquela experiência necessariamente compartilhada e heterogênea está a formulação da idéia de uma arte ambientada usada aqui. Não havia uma coordenação central, e não era um projeto de curadores ou instituições. Nós éramos a base das operações e desenhávamos sistemas de ocupação a partir do modo como eramos afetados pelos lugares que desejávamos habitar. Esta ordem horizontal e orgânica foi fundamental para que pudéssemos agir com autonomia e encontrar sentido nas relações entre o trabalho e seu lugar.

Os parques, casas e territórios escolhidos, eram lugares que reconhecíamos como emblemáticos das relações entre os moradores e espaços das cidades que visitávamos ou habitávamos. Nossa primeira ocupação foi no Solar GrandJean de Montigny no Rio de Janeiro

\footnotetext{
18 http://www.webdeleuze.com/php/texte.php?cle=194\&groupe=Spinoza\&langue=5

19 ARTE CONSTRUTORA é um projeto coletivo criado pelos artistas Jimmy Leroy, Marijane Ricacheneisky, Elcio Rossini, Luisa Meyer, Elaine Tedesco, Fernando Limberger, Nina Moraes e Lucia Koch que aconteceu de 1993 a 1996, ocupando diferentes espaços nas cidades de São Paulo (Parque Modernista), Rio de Janeiro (Solar GrandJean) e Porto Alegre ( Ilha da casa da Pólvora).
} 
(1994), casa construída pelo arquiteto que comandava a Missão Francesa, trazida no começo do séc. XIX como parte de um programa de europeização do Brasil. GrandJean de Montigny escolheu construir sua própria casa dentro da floresta e usando modos construtivos locais adaptados. O Solar preserva hoje uma camada mínima de floresta ao seu redor, que sugere uma espécie de bolha no tempo, e que o protege de uma atmosfera de decadência. Mas é justamente este isolamento no tempo/espaço que o despersonaliza e museifica. É usado como espaço de exposições de arte e administrado pela PUCRJ, que mantém sua aparência de espaço doméstico como dado histórico, recebendo pesquisadores que investigam ali modos de habitar do séc.XIX.

Assim como o Solar GrandJean foi de certa forma uma resposta de seu autor estrangeiro a necessidade de adaptação ao contexto radicalmente novo e provavelmente intrigante da vida nas cidades brasileiras, a Casa Modernista em São Paulo foi criado por Gregori Warchavchik para sua residência como um exercício de adaptação dos conceitos da arquitetura moderna européia a realidade de São Paulo, que estava tornando-se metrópole nos anos 20. A primeira casa modernista construída no Brasil teve seu projeto paisagístico assinado pela esposa do arquiteto, a brasileira Mina Klabin Warchavchik. Mina concebeu um jardim povoado de espécies autóctones e desenhou caminhos com aspecto de trilhas abertas na mata, que interligavam os vários elementos deste conjunto: casa, escritório, laboratório fotográfico, estúdio, "escolinha" para seus filhos, galinheiro, horta, piscina e vestiários, etc. Nos períodos sucessivos de abandono do Parque, que foi ameaçado de extinção e tombado como patrimônio histórico nos anos 80 , a mata foi crescendo desordenadamente ao redor da casa e porque eram espécies nativas, uma vegetação aparentemente selvagem ali se instalou. Também esconde as edificações e os limites do Parque tornando a experiência de visitá-lo uma pequena aventura de reconhecimento e descoberta. E a casa, que sofreu algumas reformas desde seu tombamento vinha sendo 
descaracterizada tanto pelas agressões que sofria com a vandalização de alguns jovens do bairro quanto pelas intervenções arquitetônicas que eliminaram elementos originais desenhados pelo arquiteto. A imagem de um projeto moderno tornado ruína, e de um jardim construído tornado selvagem, nos pareceu perfeita como lugar de pensar e agir em São Paulo. A ocupação neste caso foi mais intensa e também extensa porque trabalhamos ali por vários meses (também 1994), e concebemos nossos projetos individuais no convívio com o lugar, fizemos coletivamente uma prospecção nada científica que revelava sentidos possíveis de ação ali. Cada artista escolhia um ou mais espaços onde produzia alterações, acrescentava objetos, reorganizava elementos encontrados. Tudo era negociado em reuniões mais ou menos informais entre os artistas e eventualmente com a associação de moradores que organizou o movimento que resultou em seu tombamento e na época administrava o Parque.

$\mathrm{Na}$ apresentação dos catálogos um pequeno texto falava de nossa intenção de produzir uma "arte ambientada, disposta a assumir as influências do meio." E o título do projeto queria marcar uma diferença em relação ao conceito de arte construtiva, forte tradição na arte brasileira. Construtor é quem constrói: a ênfase está na ação de construir, mesmo que sejam estruturas temporárias, e não no objeto de arte como construção. Propúnhamos que o sentido de construir implicava agir num contexto ele mesmo já construído, operando com sentidos e relações já existentes e não a partir de um espaço idealizado, de um zero fictício que usualmente os espaços de exibição da arte procuram estabelecer. Nem o "cubo branco", nem arquitetura sobre terreno vazio nos interessavam então. Nos contextos próprios dos lugares havia o que experimentar e construir.

Os ajustes conceituais que fazíamos no corpo do projeto eram proposições tão importantes quanto os trabalhos em si. A experiência de expor alguns conceitos à prática coletiva, implicava em assumir os 
confrontos e divergências e principalmente reconhecer no espaço as forças em ação, dos artistas e do lugar.

Hélio Oiticica propunha com seus parangolés e penetráveis, um programa ambiental que instaurava novos espaços de experiência, "a fundação de um novo espaço e novo tempo (na obra no espaço ambiental)" 20 . Nós pensávamos uma arte ambientada impregnada do um lugar já existente, indistinta dele. Havia uma reciprocidade na relação das intervenções com o ambiente encontrado e o trabalho não era um projeto ou programa anterior ao lugar, derivava necessariamente dele, da experiência nele. O interesse por uma certa domesticidade foi nos levando a abandonar os espaços de exibição de arte, e a apagar os traços codificados de obras ou exposições de arte como etiquetas, textos de apresentação, etc. Nossa vontade de adaptação e integração ao meio, de pertencer a ele era também vontade de fazê-lo pertencer a nós e nossas ações. A continuidade do real como partido, e atuar sobre o estado das coisas com intervenções temporárias, tudo isso implicava em assumir uma certa dissolução destas ações, umas nas outras e no tempo.

O último dos eventos que realizamos (1996), na llha da Casa da Pólvora em Porto Alegre, foi onde os conceitos operando no projeto se tornaram mais evidentes. Fascinados pelo terreno da ilha, mas afetados principalmente pela idéia mesma de ilha, preparamos nossos trabalhos. Meu primeiro projeto tinha raiz topológica: a idéia de que uma ilha é o oposto de um lago - um campo de terra circundado por água e uma área de água circundada por terra respectivamente. A coincidência na representação destes opostos, num diagrama simples, deu origem a "Lago", linha de lâmpadas formando um diagrama fechado no centro da clareira de um taquaral. O espaço mesmo, semifechado naturalmente, se assemelhava a um ambiente construído e se

\footnotetext{
${ }^{20}$ afirmação do artista citada por Lisette Lagnado em seu texto O "além da arte" de Hélio Oiticica apresentado em simpósio realizado pela Tate Modern em 2007, por ocasião da mostra "Hélio Oiticica: O Corpo da Cor". http://p.php.uol.com.br/tropico/html/textos/2882,1.shl
} 
destacava visualmente do entorno. As lâmpadas iluminavam o centro do diagrama e nesta convergência o público se colocava espontaneamente para ver o trabalho, ou fotografar-se nele, ou até mesmo jogar capoeira. Reação imprevista que carregava de sentido o lugar transformado pelo uso. O sistema criado para alimentar de energia as lâmpadas numa ilha desprovida de energia elétrica, era um aparato físico que se impunha pelo ruído contínuo e perturbador do gerador.
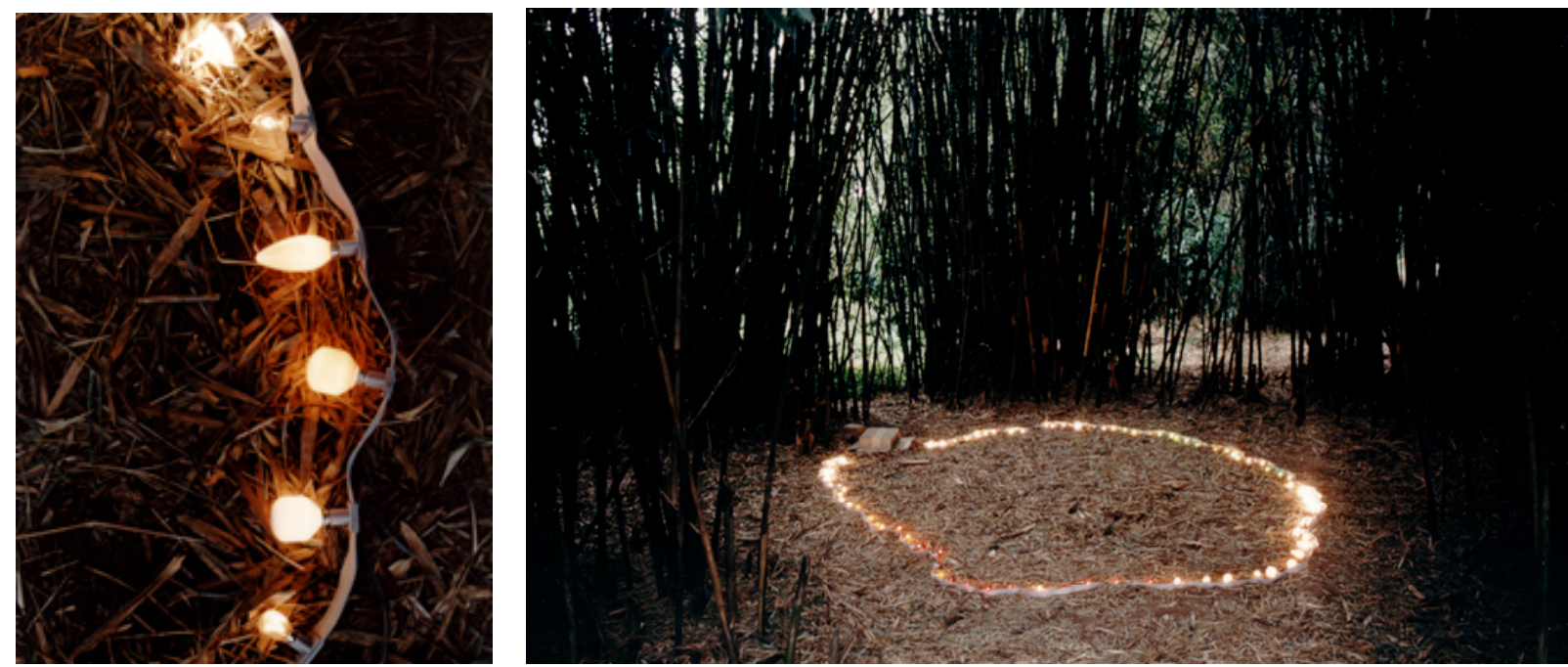

“Lago" 1996. Arte Construtora na Ilha da Casa da Pólvora

Mas frequentar aquela ilha era experiência única e específica, impossível de antecipar. E durante o período de ocupação coletiva muitos outros trabalhos foram surgindo, novos arranjos de elementos encontrados, vizinhanças negociadas, acesso a terrenos inesperados. Nossa sede durante os dias que antecederam a visitação pública foi a casa de um pescador que estava na época hospitalizado, único morador daquela área. Como ele havia acompanhado nosso projeto desde o princípio cedeu sua casa por algumas semanas para guardarmos nosso material e ao final acabou me autorizando a instalar ali também um trabalho. "Casa Própria" começou com o esvaziamento parcial da casa (os pertences de seu dono foram mantidos ali, rearranjados e cobertos) e depois a colocação de filtros nas suas janelas. 

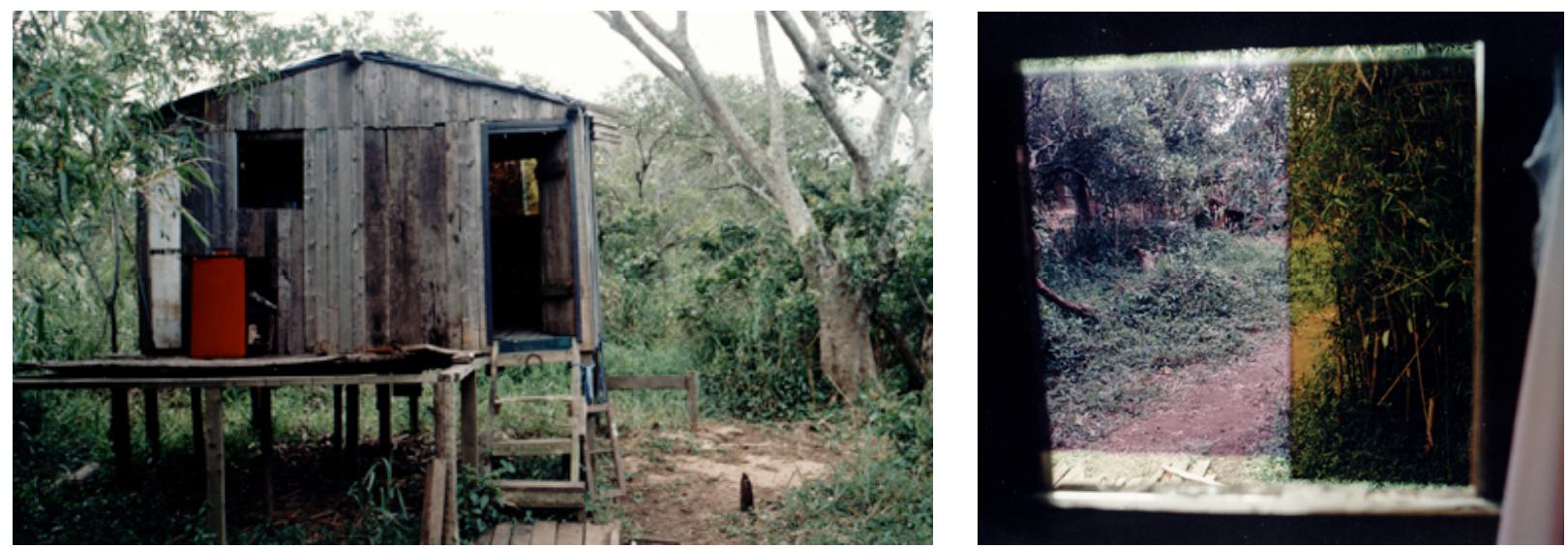

"Casa Própria" 1996. Arte Construtora na llha da Casa da Pólvora.

O terreno ao redor foi limpo e o acesso a ele facilitado. Essas operações preparatórias, principalmente de limpeza, foram fundamentais uma vez que a ilha funciona como um filtro para o Guaíba, retendo todo tipo de dejetos com as oscilações no nível do lago. Das atividades de limpar e dar acesso surgiram muitas ações e construções que não haviam sido planejadas. Pequenas intervenções que muitas vezes ao final não sabíamos quem havia feito. Trabalhos feitos pelos visitantes e convidados que desembarcavam na ilha e imediatamente iniciavam sua exploração, espalhando-se, encontrando os trabalhos que realizamos, coletando objetos, ou modificando mais ou menos discretamente - o estado das coisas. Ali já não havia sinalização de autoria, e nada que indicasse a presença de obras de arte. 


\section{MATEMÁtICA APLICADA}

Conceito surgido nos anos $70 / 80$, no terreno então ainda novo da Etnociência, Matemática Espontânea é um campo de pesquisa que questiona o sentido de conhecimento universal proposto pela Matemática Moderna. No lugar da teoria dos conjuntos como matriz para a organização e classificação do mundo, recupera a importância dos contextos sociais onde o conhecimento matemático é gerado informalmente: a matemática como produto de uma cultura - sempre própria, local. Em comum com a Matemática Moderna, há a compreensão de que as estruturas lógico-matemáticas são construções que surgem na experiência com o mundo e como resposta a problemas concretos.

A idéia de um campo do conhecimento construído fora do ensino formal, em práticas cotidianas, pode ser estendida para entender também a arquitetura que se dissemina espontaneamente, sem a intervenção de arquitetos, nas ruas e espaços domésticos das cidades.

Em “Através da Rótula”, o historiador Paulo Cesar Garcez Marins observa raciocínios construtivos e modos de ocupação a partir do estudo de um dispositivo arquitetônico: Investiga as práticas sociais criadas com o uso de balcões de rótula e treliças nas cidades brasileiras até o início do séc. XX, a partir da presença resistente deste "artefato de madeira - de uma grade - não como algo que cindia os espaços, dimensões e sociabilidades, mas que, ao contrário da interpretação tradicional, servia a sua união"21, e viabilizava a comunicação e a sociabilidade. Mesmo que formalmente houvesse descontinuidade entre espaço público e privado, a casa e a rua podiam ver-se mutuamente. A reciprocidade ou bloqueio do olhar através destes "filtros materiais" depende das condições de luz dos

\footnotetext{
${ }^{21}$ MARINS, Paulo Cézar Garcez. Através da Rotula Sociedade e Arquitetura Urbana no Brasil, séculos XVII a XX. São Paulo: Humanitas FFLCH-USP, 2001 (pág.33)
} 
ambientes comunicados e por isso mesmo é instável, muda com o passar das horas e dos dias. Era preciso ser iniciado no uso deste dispositivo para entender suas possibilidades e nuances, a distância certa, a melhor luz ou hora do dia para deixar-se ficar ali, observando, ou sondar de fora, de passagem, a intimidade da casa. O ritmo da casa e o ritmo da rua partilhando a mesma dinâmica. $O$ balcão, área da casa projetada sobre a rua e cercada de treliças, era uma espécie de intersecção entre espaços público e privado. Eram ainda, segundo Paulo Garcez, "o espaço do lusco-fusco, do trânsito tênue da luz entre o exterior e o interior domésticos(...)."22

Também os confessionários das Igrejas Católicas, aparatos tão familiares à formação religiosa elementar de boa parte da população brasileira, usam treliças, de variadas tramas. O que há em comum entre balcões e confessionários é a propriedade de estabelecer comunicação entre sujeitos colocados diante de suas duas faces, e não a condição de obstáculo visual, já que estes não escondem completamente um do outro, confessor e confessante. O lugar da fala, justamente a fala desimpedida, liberada pelas superfícies vazadas, de opacidade relativa. Pode haver portanto uma erotização do espaço com estes dispositivos semi-opacos, semi-transparentes.

O conceito de cobogó (ou combogó), que nomeia os elementos vazados usados na arquitetura modernista nasceu no Recife, assim como o emprego deste elemento na construção de fachadas inteiras. A mesma cidade que ainda conserva alguns exemplares de balcões de rótula e treliças de madeira, tão populares na arquitetura colonial brasileira e suprimidos por um esforço "europeizador" do estado no séc. XIX. Os muxarabis mouriscos e as superfícies vazadas que serviam de filtro para a entrada de luz e ar nos interiores domésticos tinham função essencial de espaço de troca e comunicação, como

\footnotetext{
22 MARINS, Paulo Cézar Garcez. Através da Rotula Sociedade e Arquitetura Urbana no Brasil, séculos XVII a XX. São Paulo: Humanitas FFLCH-USP, 2001 (pág.60)
} 
são também dispositivos de comunicação os anteparos que uso com a função de filtro em meus trabalhos.

"A luz espectral que fluía através das rótulas, continuando espaços de casas e ruas, diferia muito da claridade e da transparência materializadas pelas vidraças. Ao contrário das rótulas os vidros permitiam tanto a visualização direta quanto a fiscalização desimpedida dos interiores domésticos, o que acabaria por aguçar a necessidade de uma definitiva separação e especialização de espaços e convívios..."23

Os padrões geométricos aplicados em elementos vazados tem a função principal de existir como acontecimento visual organizando a superfície de partilha entre dentro e fora. Este domínio formal que ordena as malhas geometricamente implica num conhecimento matemático sofisticado, ainda que empírico. A complexidade nos padrões da arte e arquitetura islâmicos por exemplo, já indicava o conhecimento de conceitos da geometria moderna, em construções do período medieval. Mesmo operando com padrões menos complexos, os elementos cerâmicos ou de cimento tão freqüentes nas cidades brasileiras, se afirmam como ordem inventada, sinal de capacidade de organização mental, engenhosidade que confronta adversidade. Sinal de alguém ali pensando. A pesquisa destes elementos arquitetônicos segue um princípio próprio da tradição modernista no Brasil, de recuperação de algo passado que fala no presente, como ação de resistência cultural e afirmação da diferença.

Um pensador fundamental no campo da arquitetura, no projeto moderno brasileiro, é Lucio Costa. Sua pesquisa obre a linguagem arquitetônica, intensificada em sua atividade no Instituto de Patrimônio Histórico Nacional particularizou também sua produção como arquiteto e o fez incluir em seus projetos mais autorais e

\footnotetext{
${ }^{23}$ MARINS, Paulo Cézar Garcez. Através da Rótula Sociedade e Arquitetura Urbana no Brasil, séculos XVII a XX. São Paulo: Humanitas FFLCH-USP, 2001(pág.43)
} 
modernos, elementos vazados derivados das treliças e balcões de rótula tão emblemáticos da arquitetura colonial brasileira e de sua influência mourisca. Mas a presença destes elementos recriados num campo completamente novo então, expandidos, redesenhados, não aparece como citação ou referência nostálgica, embora evoque uma certa familiaridade como ponto de partida.

O que Lucio Costa projeta são planos semi-transparentes que se combinam em sobreposições, criam passagens, transparências, e uma circulação entre os ambientes que é própria do pensamento espacial que correspondia ao programa moderno. E o faz retomando elementos que haviam sido negados pela arquitetura vigente, uma vez que com o surgimento das vidraças foram taxados de obsoletos. Mas o cobogó tem, se comparado ao vidro, a vantagem de fazer circular também o ar e não apenas luz. Outra diferença é a estrutura formal - mais ou menos ornamental dependendo da intenção do autor - que intercepta a visão de exterior e interior, e também a entrada de luz natural nos ambientes. Os efeitos desta luz filtrada, reduzida em intensidade e projetando desenhos de suas sombras, são sempre cambiantes, pois o ângulo de incidência, intensidade e cor mudam o tempo todo ao longo do dia.
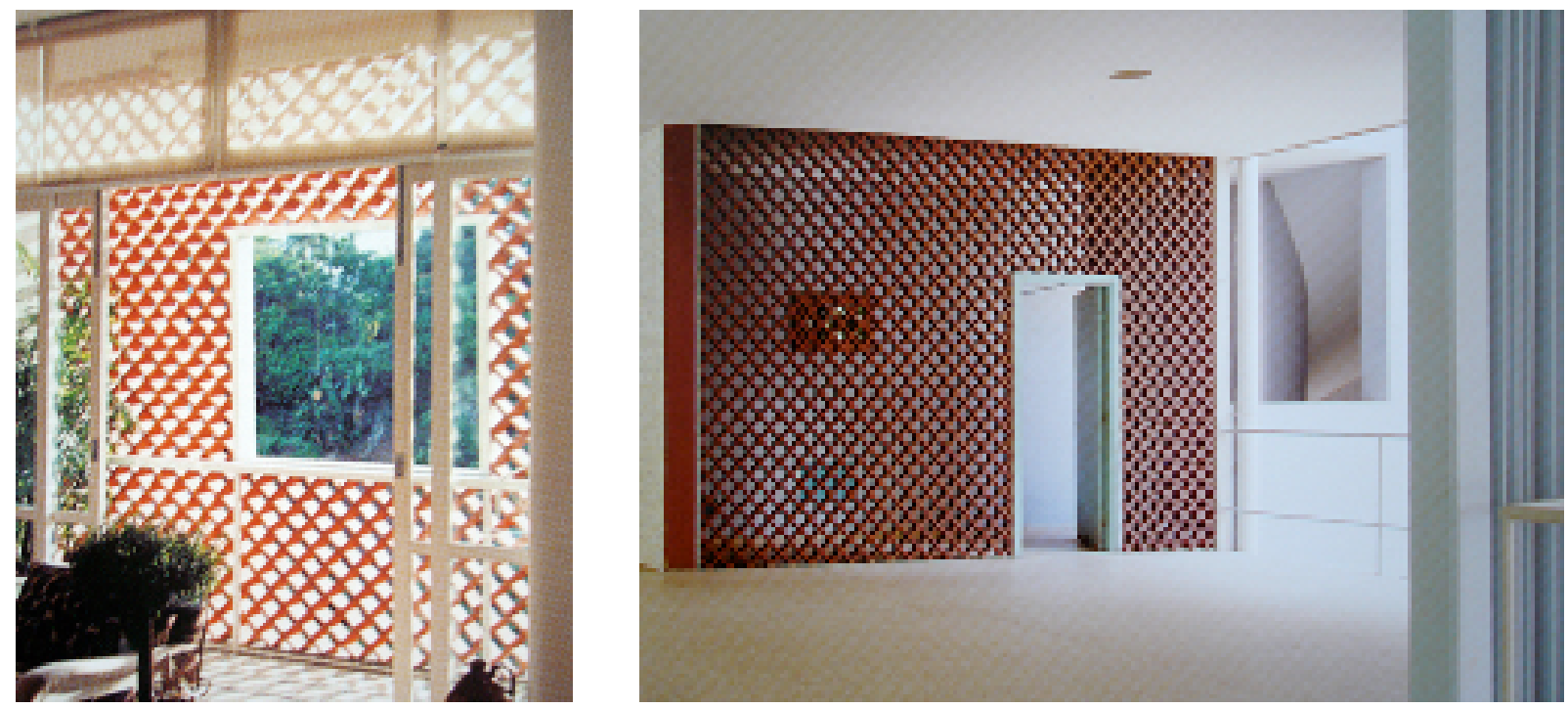

Lucio Costa. Edifícios do Parque Guinle, Rio De Janeiro, 1943-54 
Guilherme Wisnik observa a respeito do uso de cobogós nos edifícios do Parque Guinle, projetados por Lucio Costa: "Como resultado final, a riqueza decorativa linear não aparece como um capricho dissonante, mas como uma espantosa trama de cheios e vazios, que se integra na ortogonalidade rigorosa dos prismas e dilui a função de vedo atribuída a fachada. Sua aparição figura a possibilidade ideal de uma edificação inteiramente vazada, desmaterializada, pois tem o ar como matéria constituinte. Por outro lado, nada mais contrastante em relação a imaterialidade da arquitetura contemporânea, exemplificada nas peles de vidro de Jean Nouvel, do que na presença tátil e cromática dessa cerâmica recortada e multiplicada" 24 .
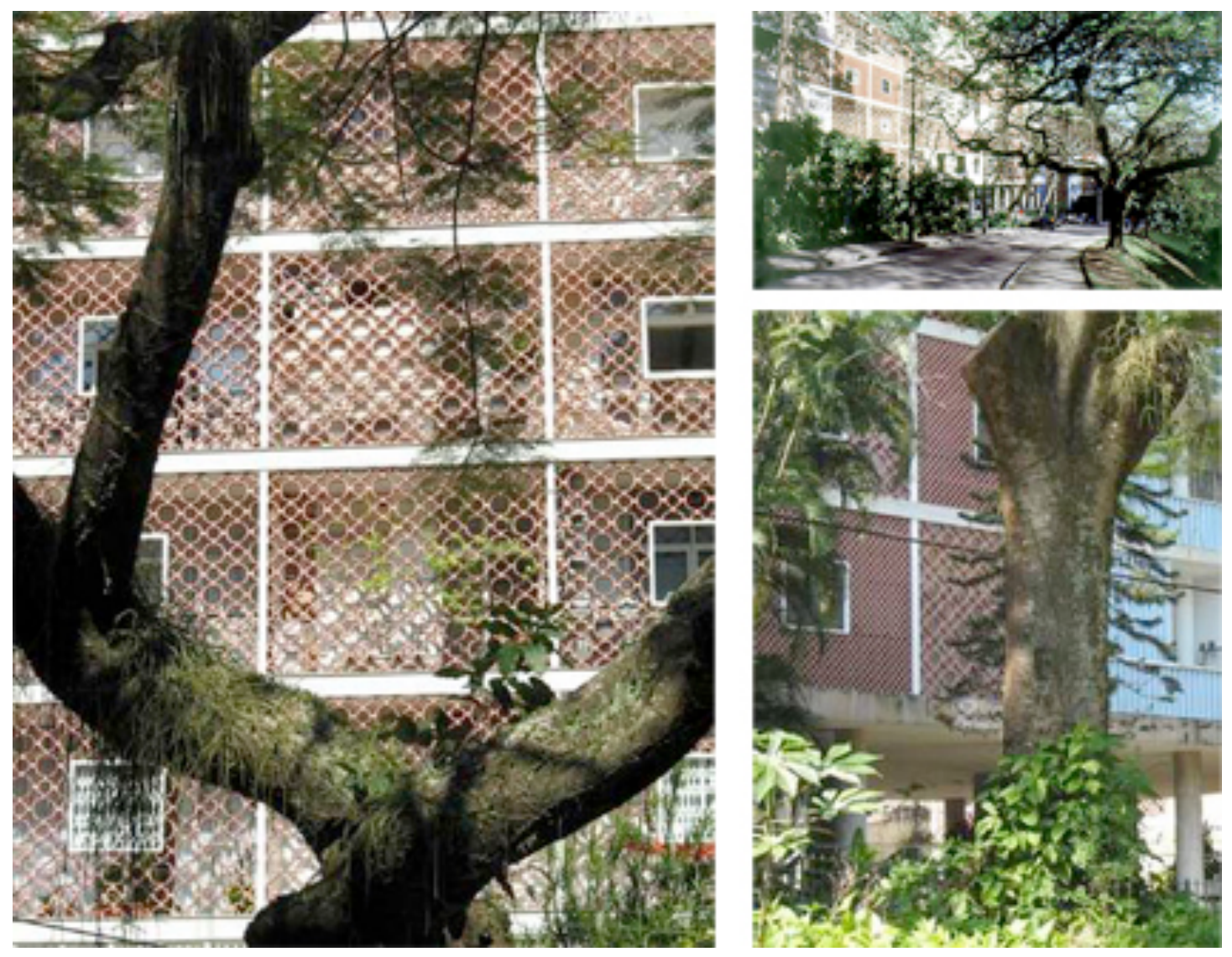

Cobogós nas fachadas dos Edifícios Bristol e Caledonia - Parque Guinle

\footnotetext{
${ }^{24}$ Guilherme Wisnik: "Lucio Costa - Entre o empenho e a reserva" in LUCIO CostA. São Paulo: Cosac \& Naif Edições, 2001
} 


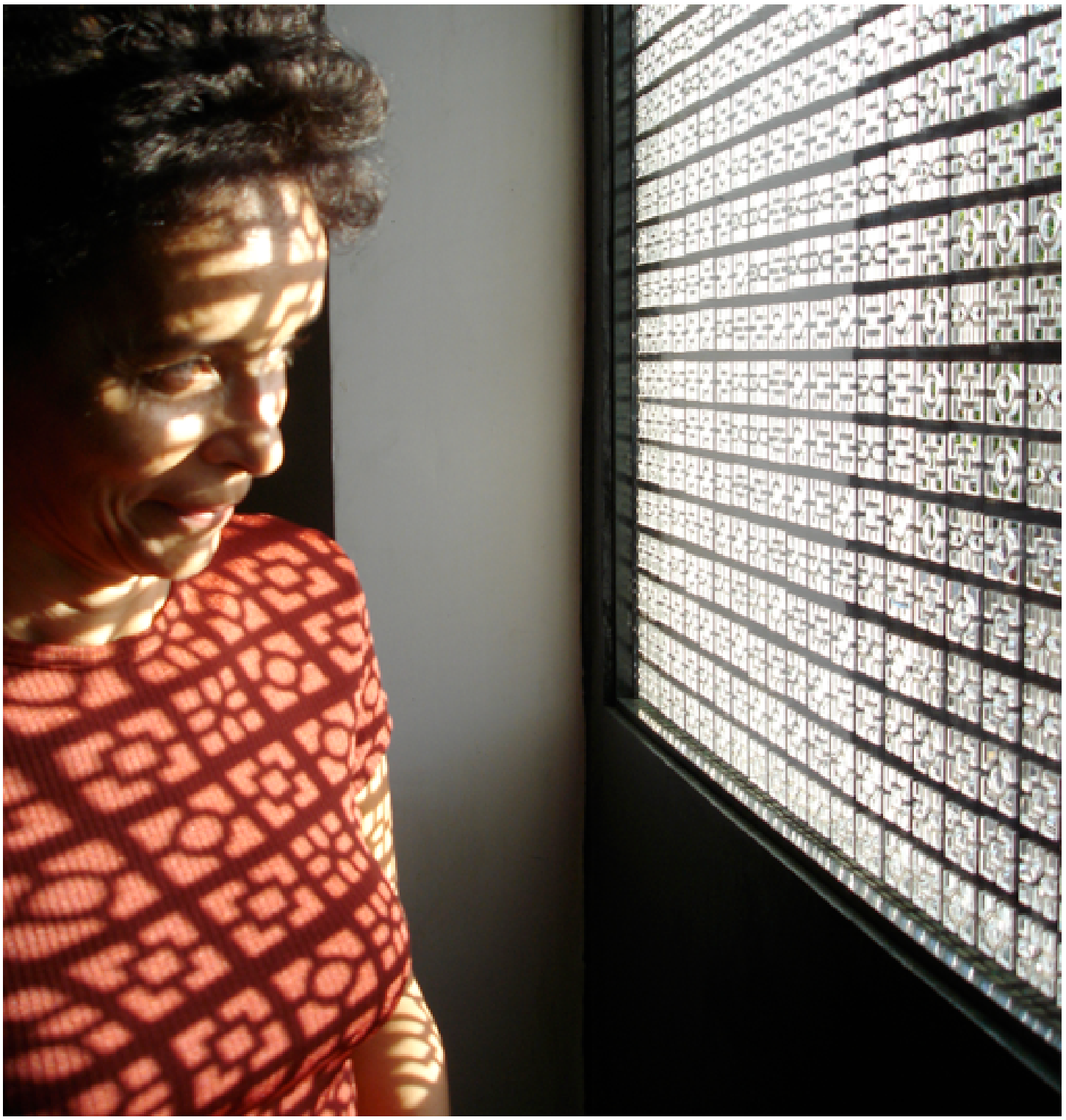

"Matemática Espontânea" - Torre Malakoff, Recife, 2006

Matemática Espontânea é o título de uma série de intervenções criadas para a Torre Malakoff Observatório Cultural. A Torre abriga o primeiro observatório construído em Recife e seu prédio é identificado como exemplar de estilo "oriental", denominação vaga que imagino se refere a forma de alguns de seus ornamentos e janelas. As quatro salas de exposição estão dispostas em dois eixos de simetria, duas a duas, formando salas compostas. Desde a reforma feita para adaptação do prédio e criação de espaços expositivos, as aberturas existentes foram cobertas por paredes "falsas" e a luz e ventilação controladas artificialmente. 
A primeira intervenção foi coordenar a retirada das paredes de MDF que cobriam as aberturas, reavendo as quatro janelas, uma em cada sala. Foi necessário algum restauro nas paredes originais, retirei as portas e venezianas temporariamente, e também algumas tapagens reduzindo as áreas abertas e alinhando-as no eixo da entrada de luz natural e da circulação de ar. O material e a cor do acabamento são idênticos aos encontrados nas janelas, e o modo de adaptar as aberturas imita um princípio que já havia observado em outros pontos do edifício.
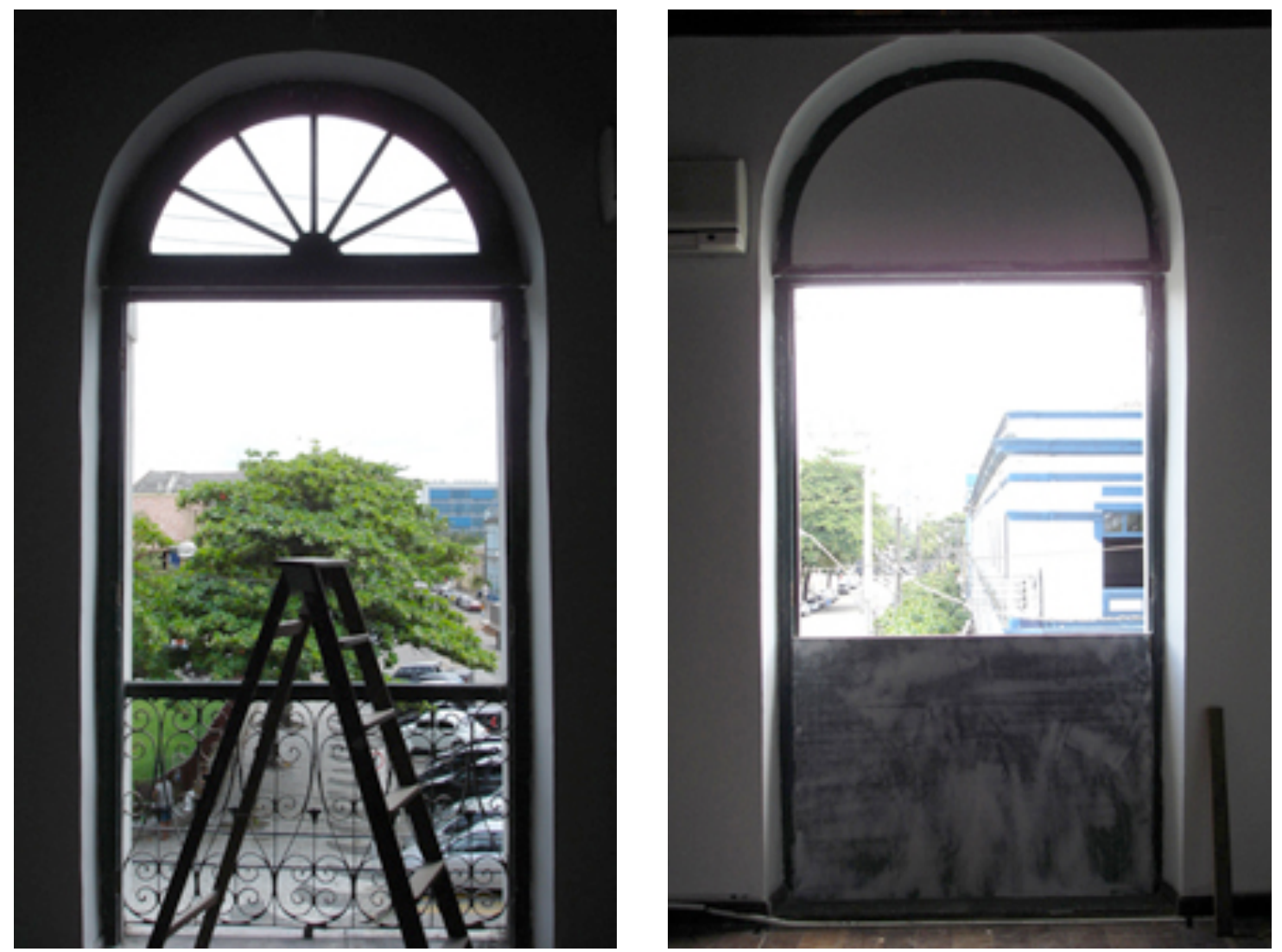

Vi as salas da torre como um conjunto de diagramas simétricos a ser experimentado pelo visitante, portanto um espaço de relações e fluxos que tinha sua topologia adaptada pela função de sala de exposição de arte. Matemática Espontânea é o conjunto de operações feitas no lugar para reencontrar este espaço. 


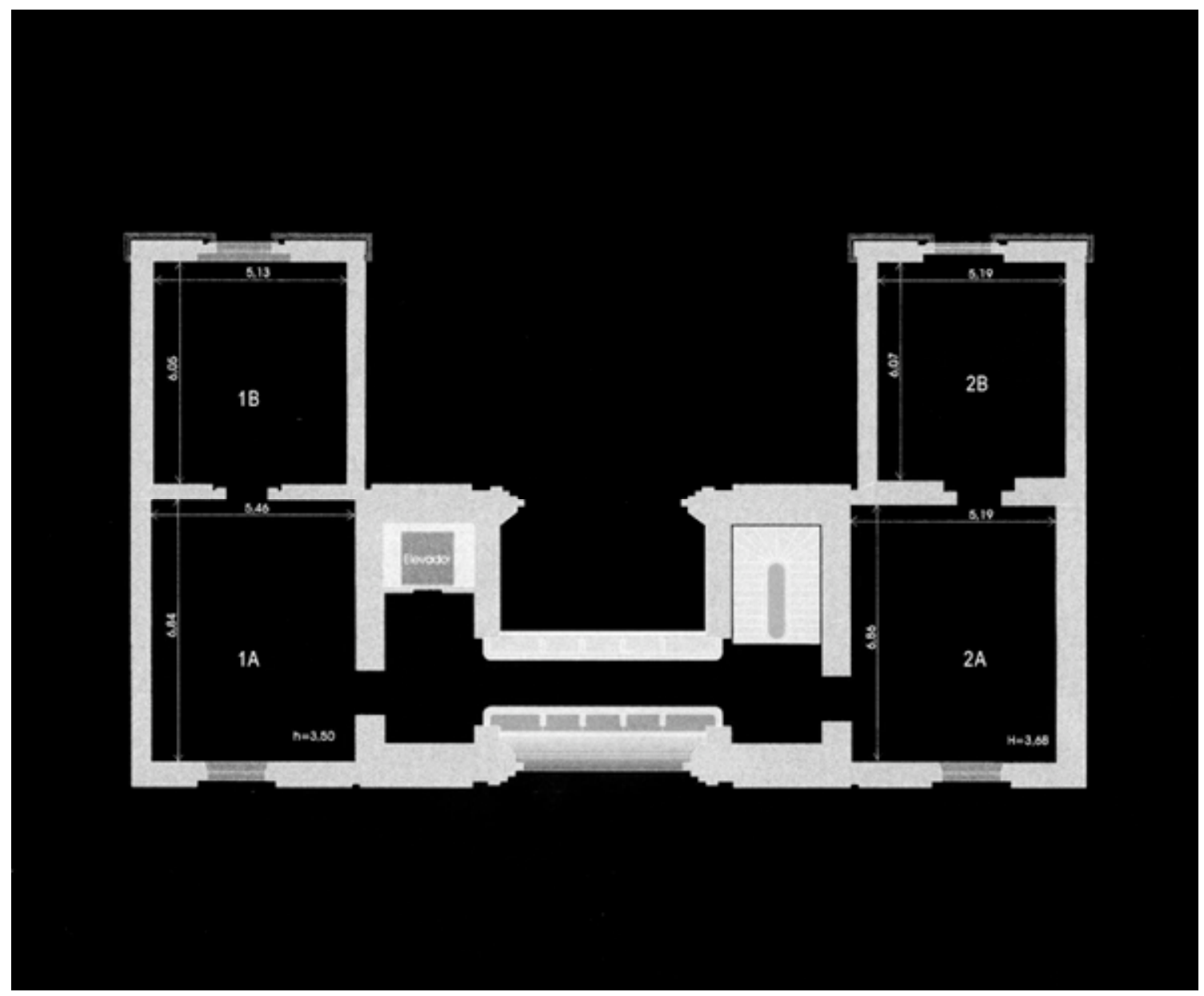

$4+1=$ As 4 aberturas foram cobertas com chapas de materiais mais ou menos transparentes, e recortados a laser com padrões inspirados em elementos arquitetônicos. Os desenhos são vetoriais, criados no computador a partir de extensa pesquisa e documentação fotográfica de cobogós, e servem de matriz digital para o corte na máquina a laser. Dois padrões foram desenhados e recortados em dois materiais diferentes (MDF e acrílico). As salas contíguas tinham em suas janelas o mesmo padrão, na face oeste - salas $1 \mathrm{~A}$ e $2 \mathrm{~A}$ - as recortadas em acrílico e na face leste - 1B e 2B - as recortadas em MDF pintado de verde, o mesmo verde colonial das esquadrias originais. As peças em acrílico eram dois espelhos, um claro e outro escuro: na sala $1 \mathrm{~A}$ acrílico espelhado comum e na sala $2 \mathrm{~A}$, uma chapa vermelho escuro que apesar de transparente se tornava mais e mais reflexivo a medida que o dia escurecia. Também o acrílico espelhado era percebido mais ou 
menos como espelho dependendo da quantidade de contra-luz natural, e a medida que anoitecia esta espécie de grade escura se tornava um espelho cheio de pequenos vazios que fragmentavam a imagem do interior da sala ali refletida.
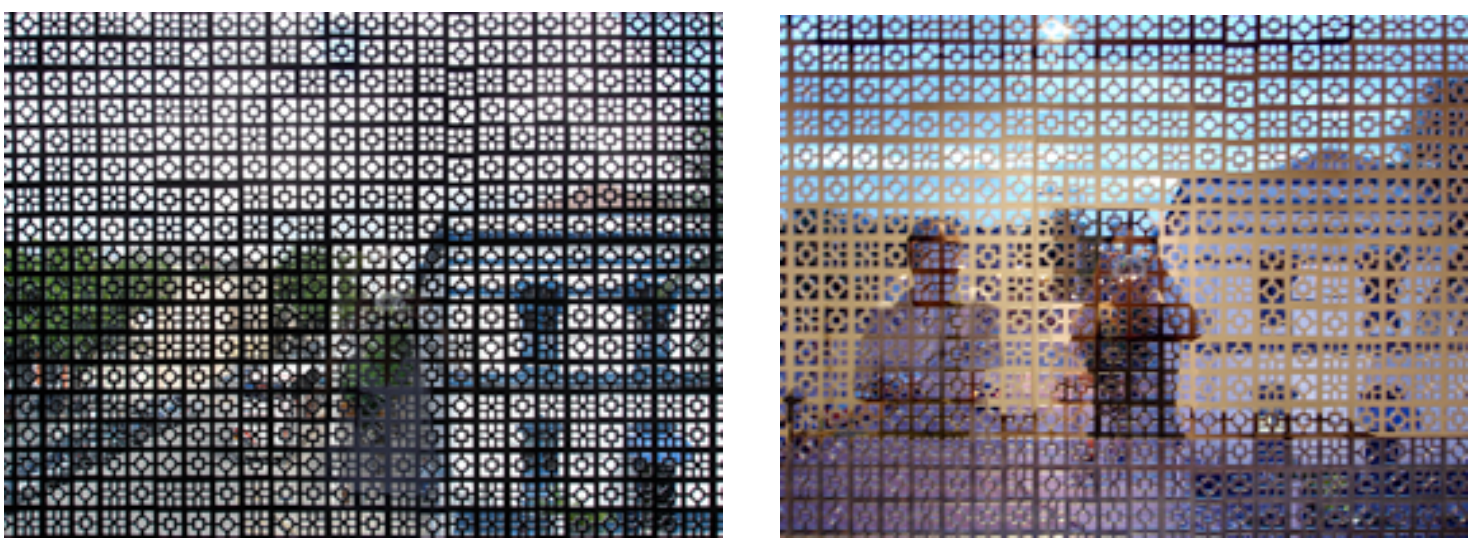

Imagens do filtro-espelho instalado, em diferentes momentos: ao meio-dia e ao anoitecer

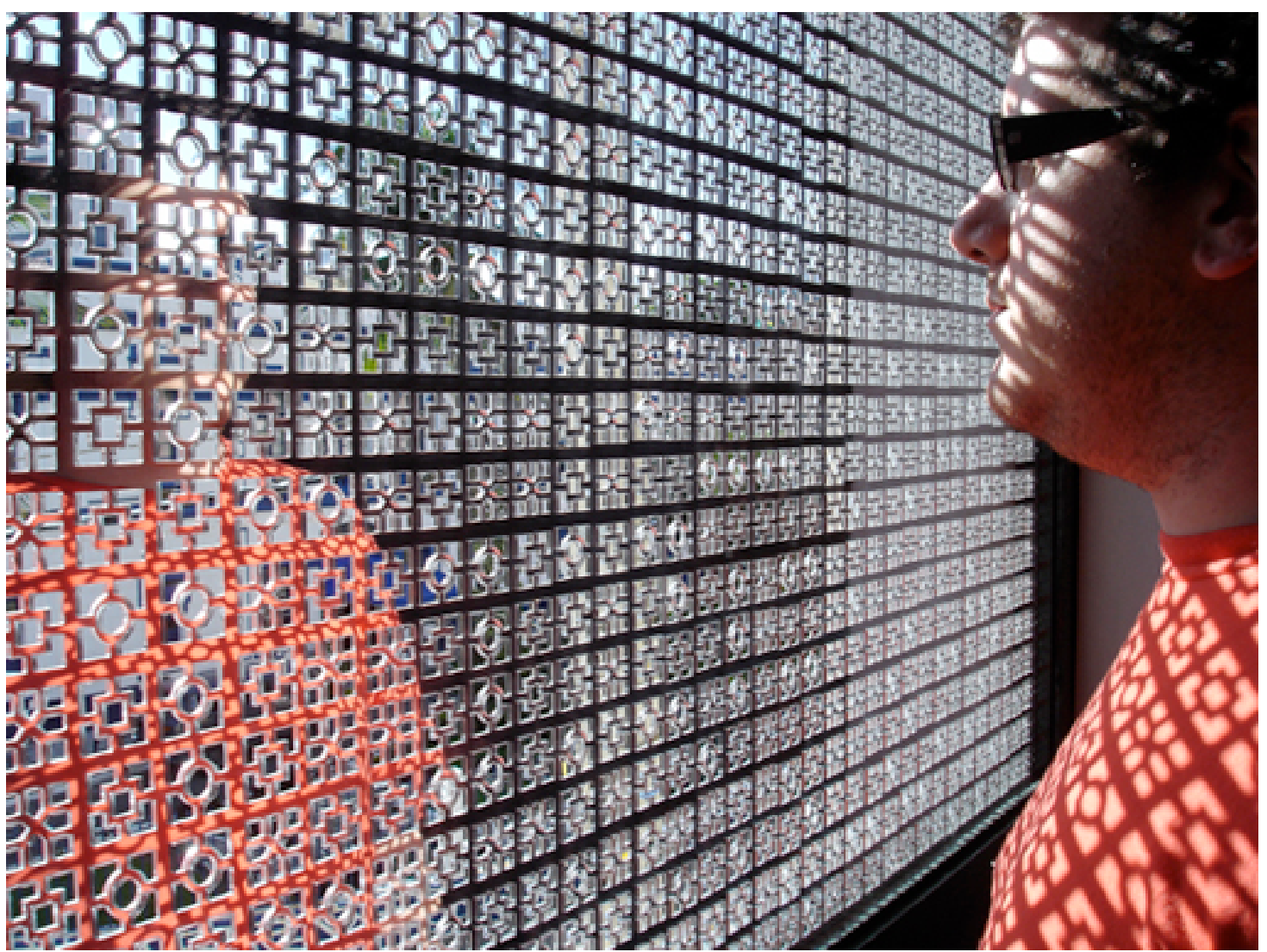

Matemática Espontânea - visitante olha através do filtro-espelho dentro e fora misturados e é também superfície de projeção 

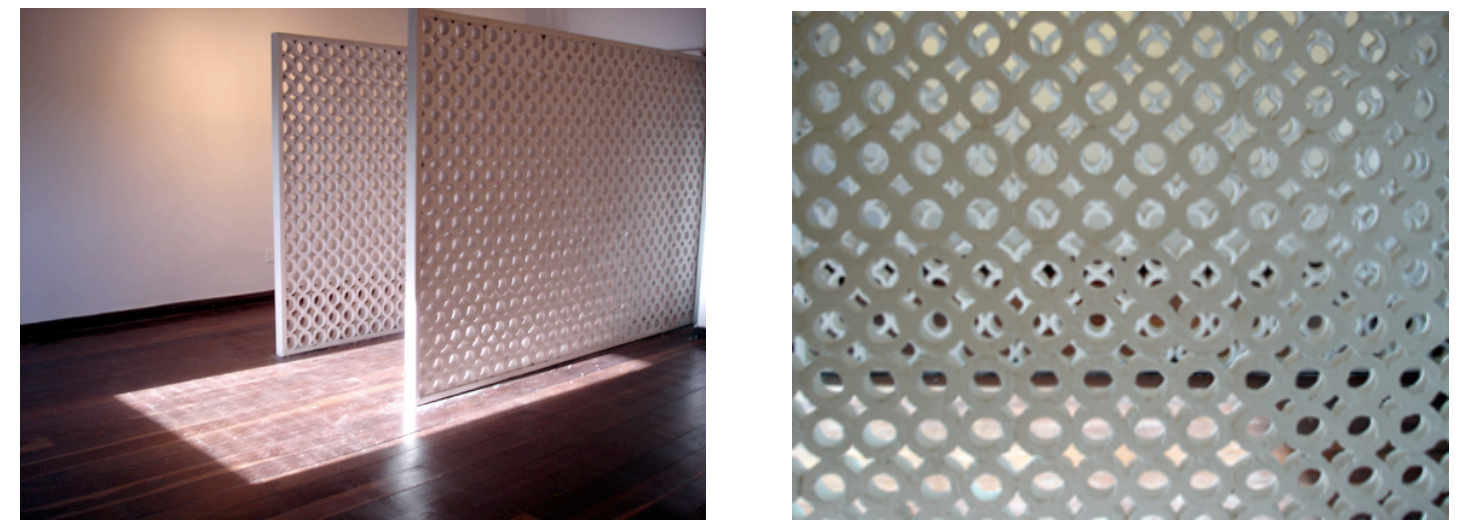

Matemática Espontânea - corredor construído em cobogó de argamassa

$2 \times 2=$ Entre as salas contíguas $1 \mathrm{~A}$ e $1 \mathrm{~B}$, e $2 \mathrm{~A}$ e $2 \mathrm{~B}$ havia uma abertura nas dimensões de uma porta, alinhada às janelas descobertas das duas salas. Um eixo importante de circulação de luz e ar que escolhi redesenhar, colocando duas paredes iguais e paralelas atravessando esta passagem e conduzindo o visitante de uma janela a outra. Paredes arejadas, feitas de cobogós de argamassa muito comuns na arquitetura popular do Recife: um deles tem o formato de uma veneziana e dirige a luz para cima ou para baixo e o outro gera uma grade feita de círculos, uma espécie de renda de argamassa, muito transparente. As duas paredes paralelas formam um corredor aberto que quando visto por fora as sobrepõe, criando no caso dos cobogós círculos, um moiré como os já experimentados em trabalhos anteriores com outros materiais. Os dois corredores repetem extensão e posição nas salas duplas e foram pintados de branco depois de construídos.
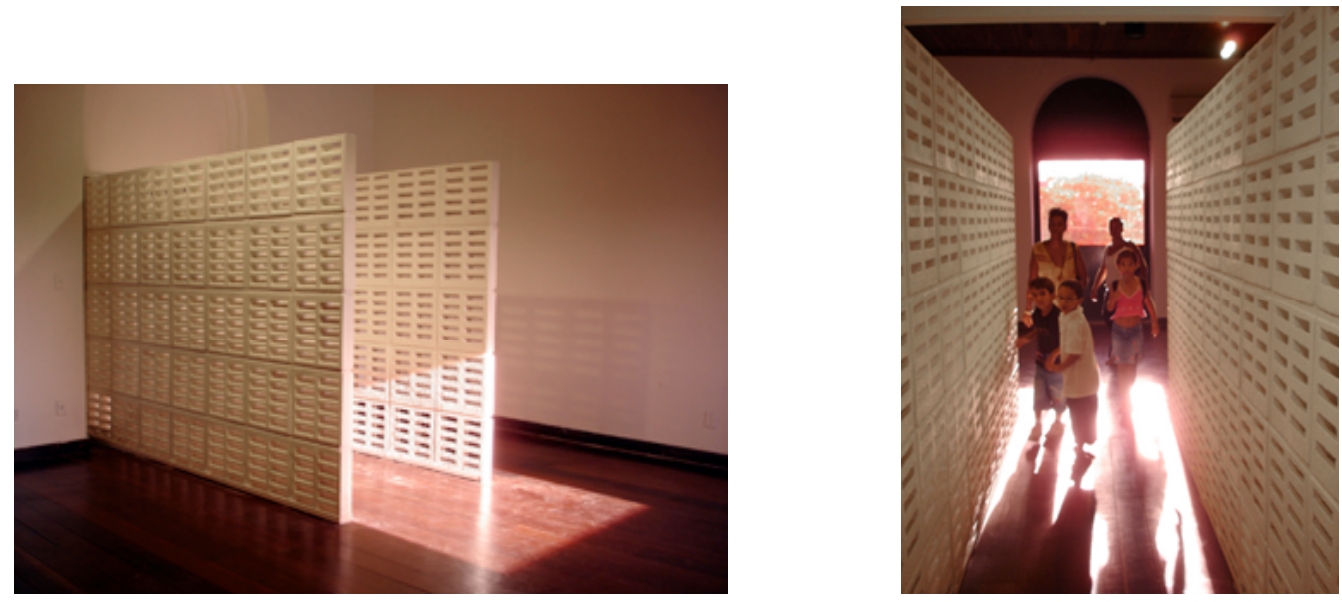


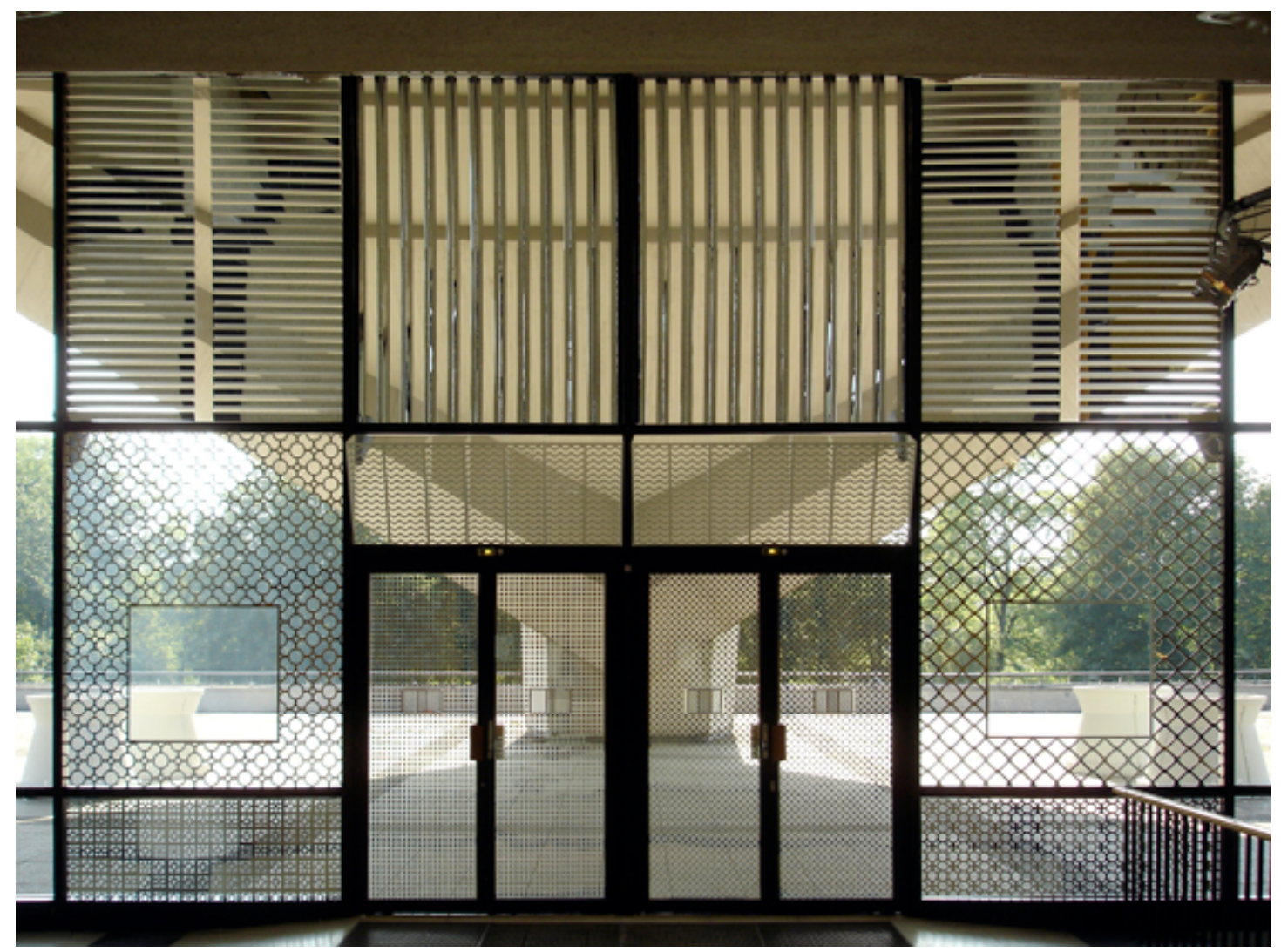

Dein Spiegel. HKW, Berlin, 2006

Dein Spiegel ("Seu Espelho", em português) foi criado para a exposição chamada "Interventions" que aconteceu na Haus der Kulturen der Welt, em Berlin, 2006. A proposta do curador Luis Camilo Osório para os artistas (também participavam Nelson Leirner, Carla Guagliardi e Chelpa Ferro) era de criarmos intervenções nos espaços de circulação da HKW. A nova pele de acrílico espelhado, colada aos vidros da fachada curva, era um conjunto de elementos inspirados na arquitetura popular brasileira: padrões recortados que foram desenhados a partir de modelos conhecidos de cobogós; "venezianas" e brises verticais feitos com prismas espelhados; basculantes. Embora reconhecíveis para aqueles familiarizados com esta arquitetura, para o público freqüentador daquele espaço, usualmente alemães e outros europeus, as retículas eram lidas como semelhantes a elementos arquitetônicos hindus, árabes, otomanos, ou asiáticos. Não-ocidentais, e portanto exóticos. 
O trabalho foi concebido para um espaço que se define como Haus der Kulturen der Welt - Casa das culturas (do resto ${ }^{25}$ ) do mundo, onde se exibe a produção cultural não norte americana e não européia, considerando estas já excessivamente exibidas em todos os demais espaços culturais da cidade de Berlin. O perfil do lugar, uma espécie de "palácio do exotismo", me sugeria justamente expor os visitantes a um espelho exótico de origem imprecisa, ignorada. Um espelho descontínuo interrompido a todo momento pela imagem do exterior, pela imagem do parque Tiergarten. Os padrões usados em conjunto se assemelham de fato a muxarabis islâmicos, justamente porque os cobogós modernos brasileiros, popularizados na arquitetura atual, são derivados não apenas do brise soleil corbusiano, mas também das treliças largamente utilizadas na arquitetura colonial tão influenciada pelas raízes deixadas em Portugal em séculos de ocupação árabe. Quando a escala é transformada como acontece nestas chapas recortadas o padrão reassume aspecto de treliça, de anteparo vazado que atua com sua transparência parcial para acrescentar complexidade a experiência do sujeito no espaço.

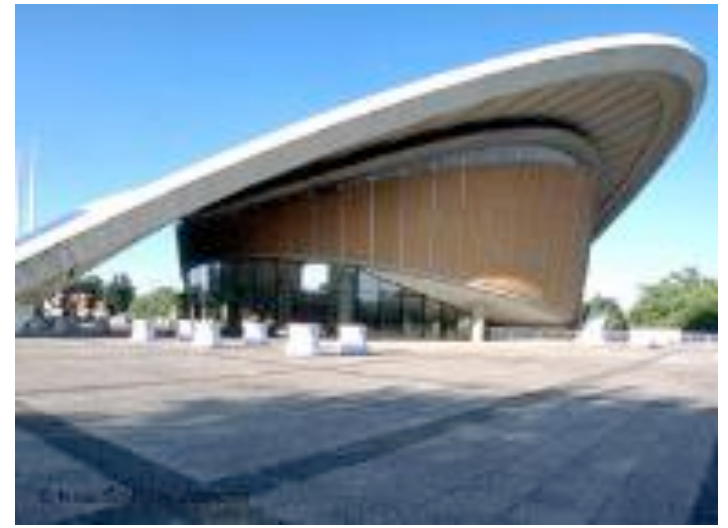

Haus der Kulturen der Welt, Berlin

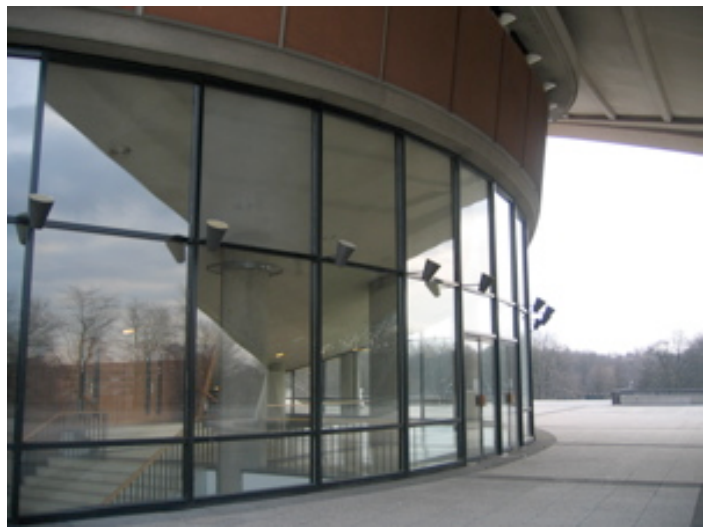

Área da intervenção, vista externa

\footnotetext{
25 Estas palavras são acrescentadas ironicamente e com frequência quando moradores de Berlin se referem a este espaço, por isto sua inserção aqui, de certa forma ajudando a esclarecer o papel da instituição no cenário cultural local.
} 


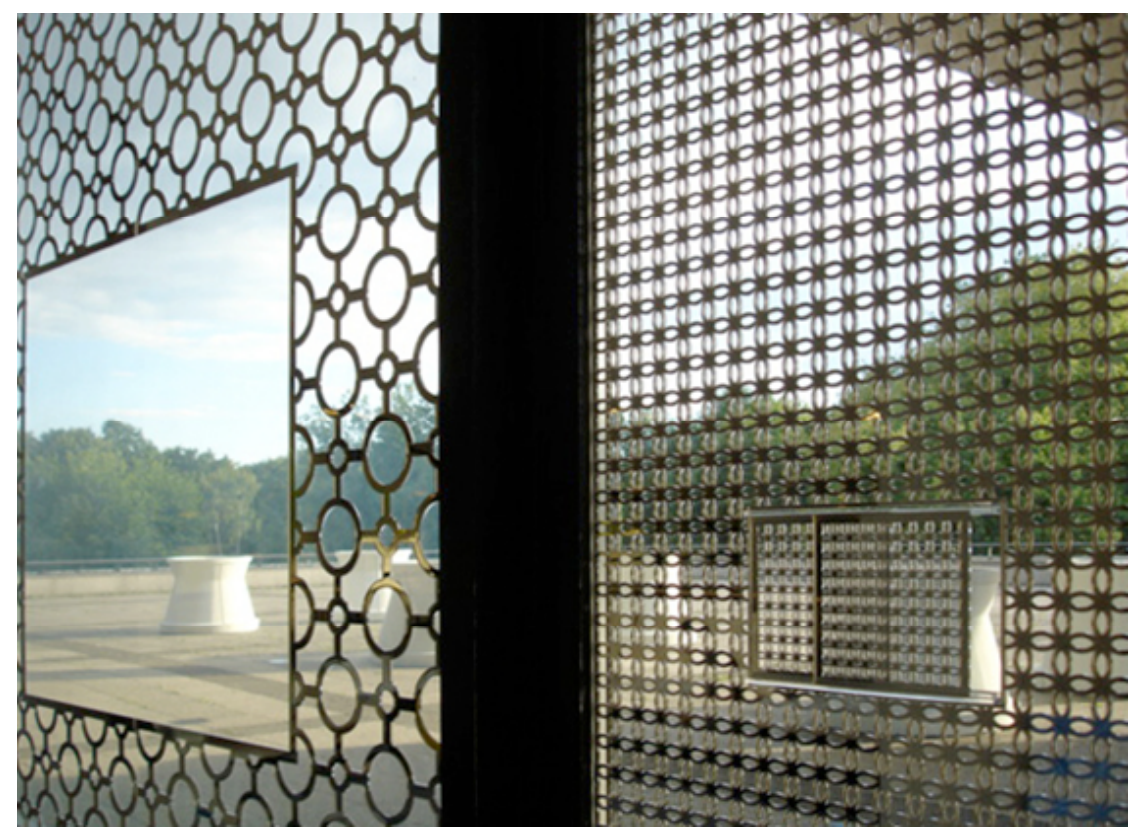

Algumas aberturas à maneira de janelas foram desenhadas e cortadas nas placas espelhadas, formando quadros vazios dentro do campo dos padrões. Nas portas de vidro, cobertas com os padrões em menor escala pareciam haver pequenas janelas como as que usamos nas casas brasileiras. Cruzando as duas placas deslizantes fixadas em trilhos também colados aos vidros os padrões se sobrepunham gerando outros desenhos de padrão, em movimento.

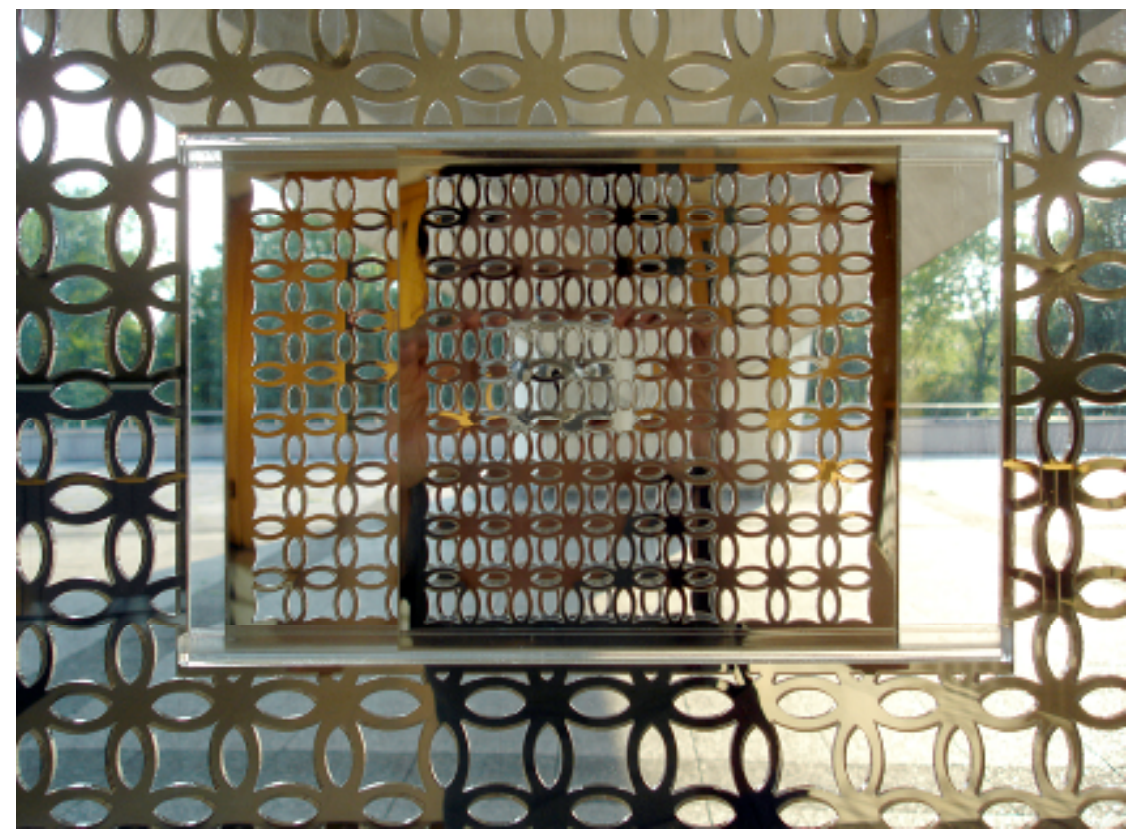


Dein Spiegel é uma homenagem a Lucio Costa. Dois dos padrões usados são inspirados nos cobogós que o arquiteto empregou no projeto dos prédios do Parque Guinle, no Rio de Janeiro. Este exemplo único da citação de um fato arquitetônico pode ser lido e identificado por aqueles que já viram imagens ou visitaram estes prédios, um dos projetos mais relevantes do arquiteto. E de qualquer forma são desenhos familiares aos habitantes das grandes cidades brasileiras. As "janelas" são recortadas aqui também a maneira como Lucio Costa o fez nas fachadas dos edifícios, enquadrando a paisagem, marcando um campo de transparência total que torna evidentes as variações neste aspecto.
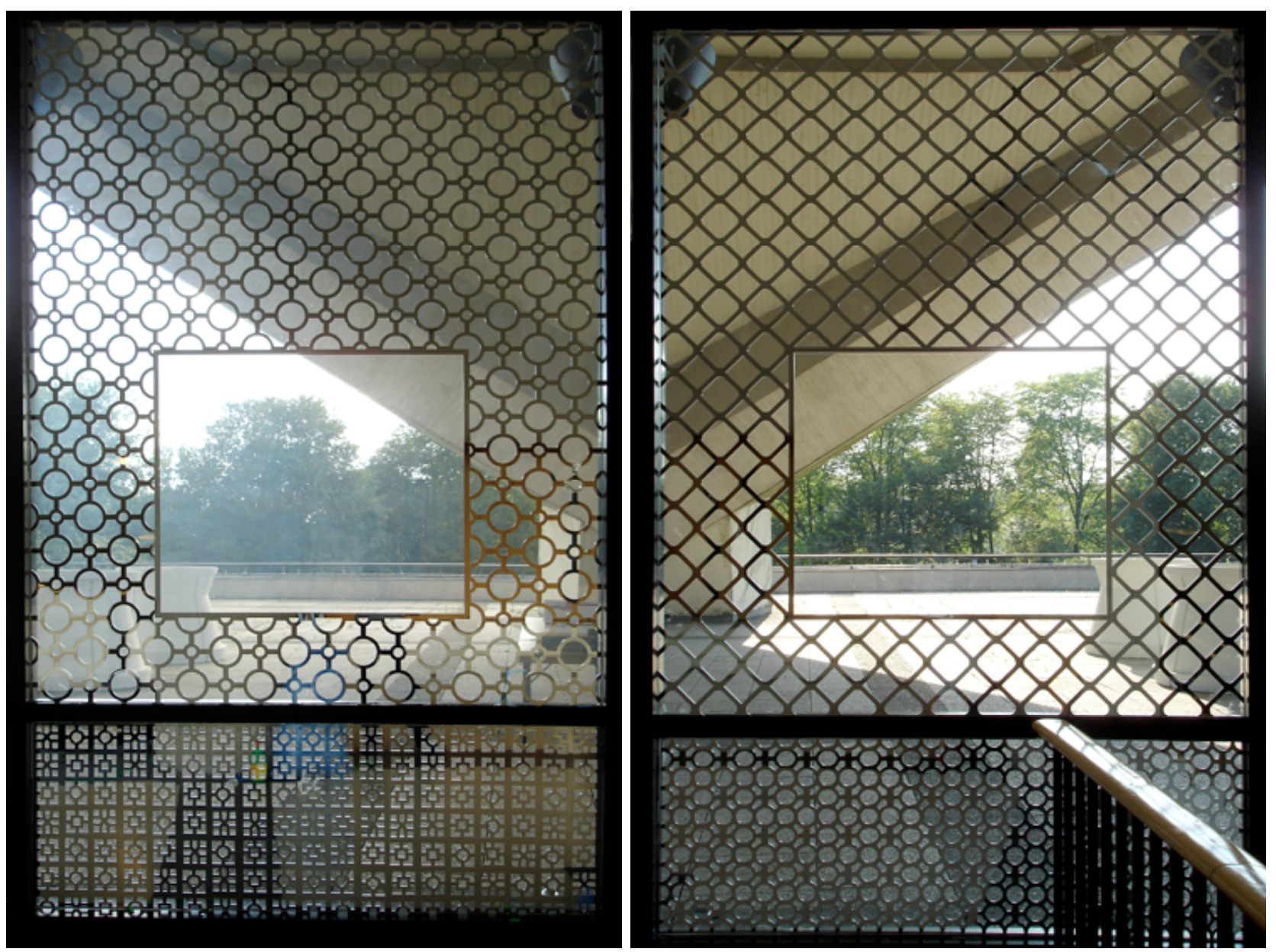

"janelas" laterais de Dein Spiegel, padrões inspirados em cobogós cerâmicos que Lucio Costa desenhou para os Edifícios do Parque Guinle 
Os anteparos recortados e semi-transparentes usados em Matemática Espontânea e também em Dein Spiegel, atraem para seu atravessamento e atuam como filtros "misturadores". Misturam dentro e fora, nos deixando ver o exterior recortado pelo reflexo do espaço interno. O efeito multiplicador se acentua quando a luz do sol incide diretamente nas janelas, pois o sujeito que observa de perto se vê refletido no padrão recortado com o desenho do padrão projetado no seu corpo. Ou experimenta as manchas de cor desta grade que se distorcem em seu corpo, movendo-se para descobrir novos efeitos. Quando se opera com a luz incidindo no espaço, isto coloca o sujeito necessariamente na condição de superfície de projeção. Uma superfície móvel, que dá visibilidade a luz transformada que atravessa o espaço, e também afeta esta luz como anteparo que reflete e produz sombra. O corpo - o seu e o do outro é um instrumento não apenas para ler as alterações mas para explorá-las e fazê-las aparecer. Prática especulativa para além da idéia de pura fruição sensorial, uma vez que este corpo é sujeito, pensa sua condição de superfície e (re)age deliberadamente no espaço para provocar efeitos.

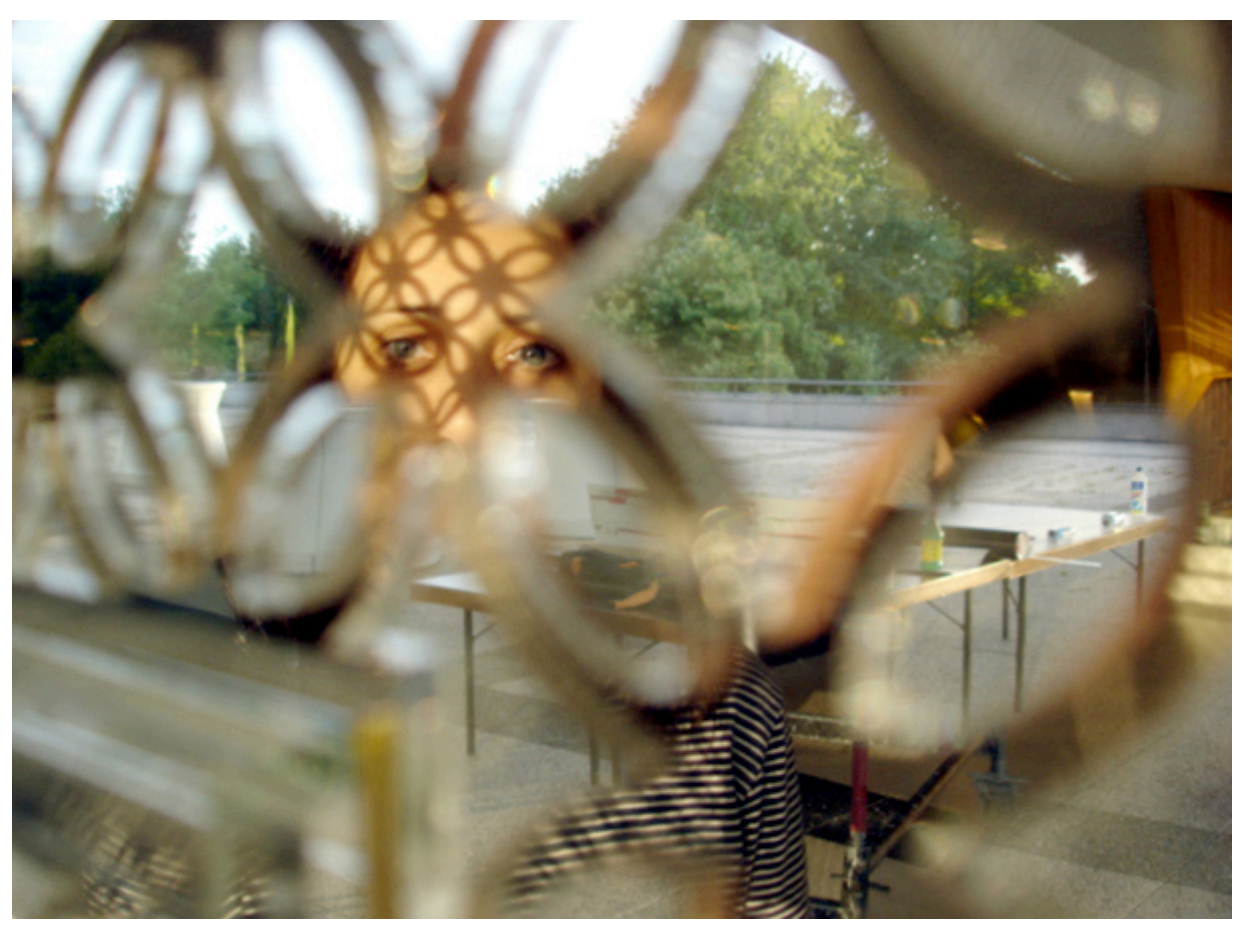




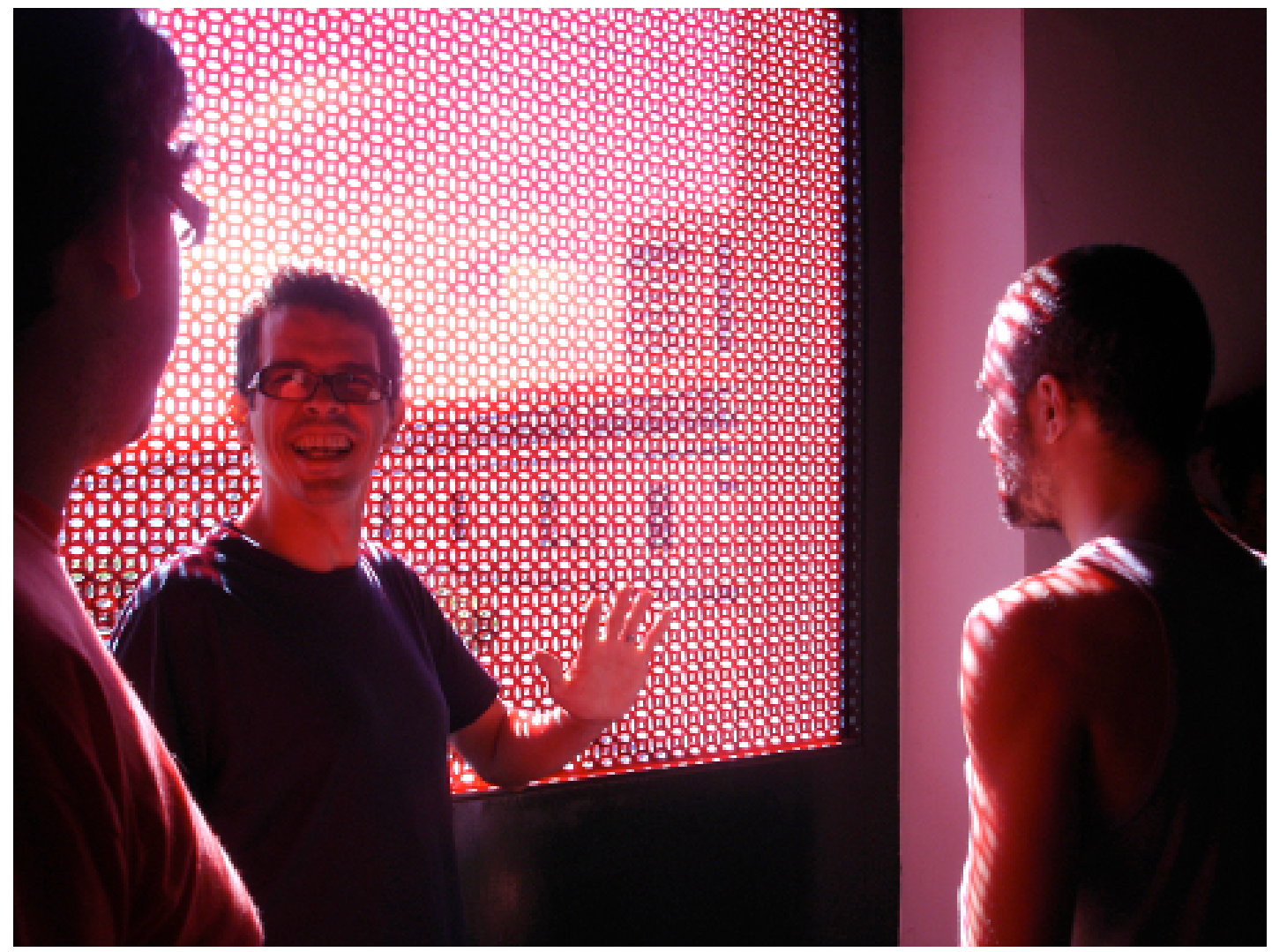

Matemática Espontânea, Torre Malakoff, 2006 (acrílico recortado a laser)

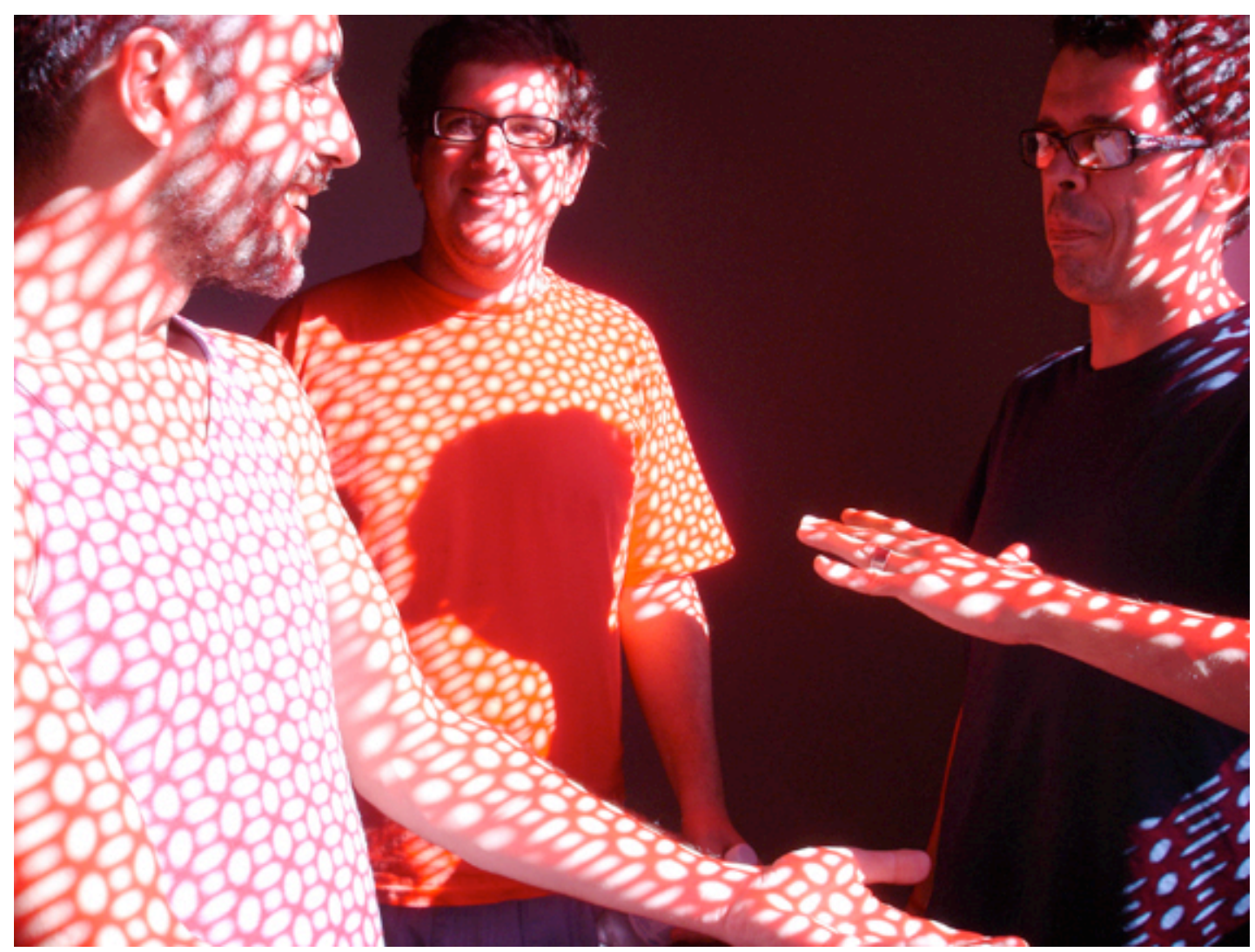


Os desenhos dos padrões foram feitos a partir de uma pesquisa de modelos existentes de elementos vazados, mas a escala no caso destes recortes é bem menor que a original, criando quase retículas que parecem "digitalizar" as imagens do exterior. Com isso se evidencia a condição de imagem na experiência, delimitada pelas esquadrias e mediada por estas estruturas reticulares.

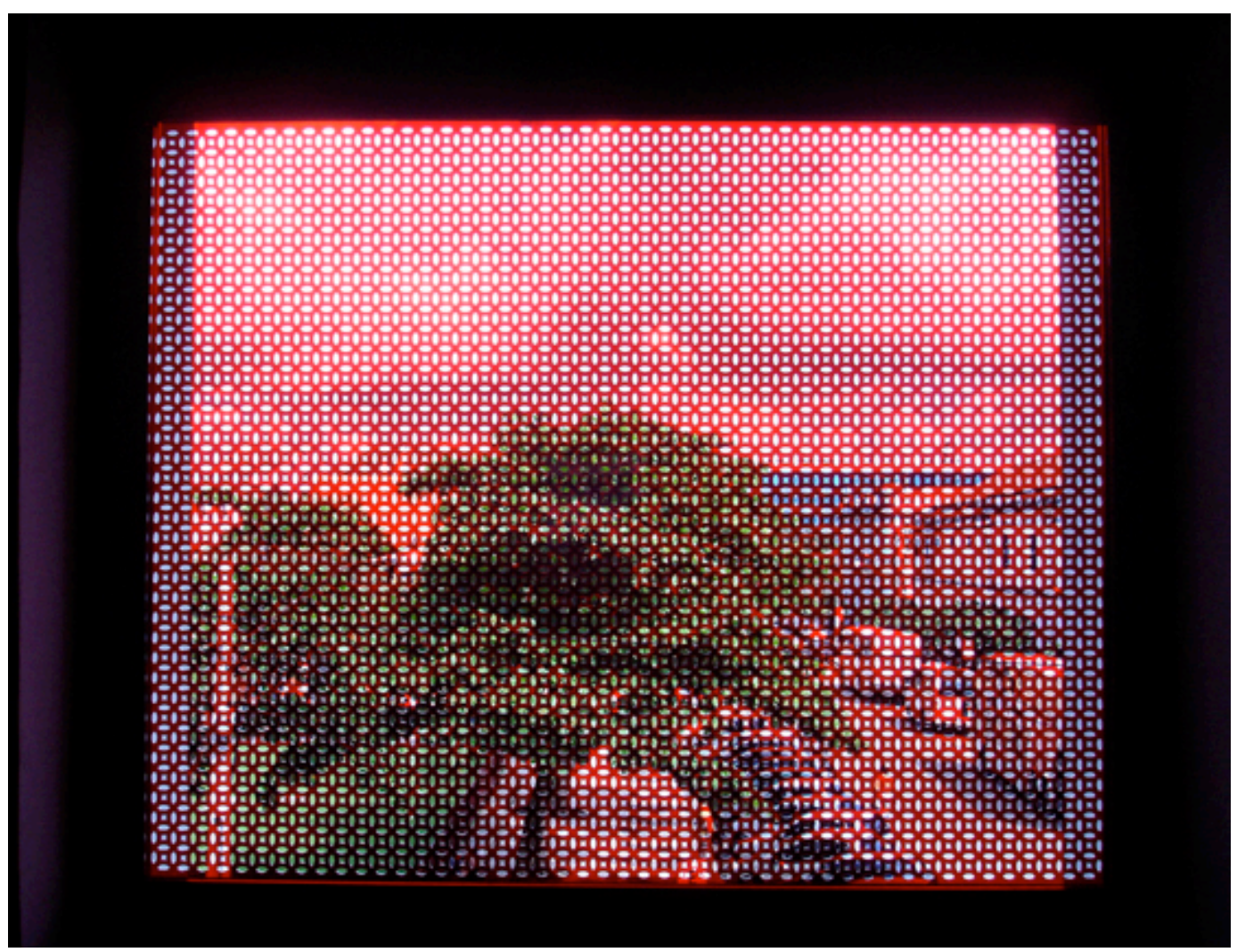

Tanto filtros de cor quanto elementos vazados são dispositivos reconhecíveis no universo contemporâneo, integrados à vida nas cidades. É sua atualidade que importa e não uma referência a traços da arquitetura colonial ou modernista. Os padrões recortados e elementos vazados são recolocados em aberturas e passagens, porque são encontrados na arquitetura popular brasileira de hoje. Sua popularidade atual indica um sentido engendrado numa cadeia de influências significativas desde os elementos mouriscos na arquitetura portuguesa até os cobogós modernistas. Mas o que dá sentido a sua presença hoje é o modo de operar destes elementos num terreno singular em que criar obstáculos vazados e de 
transparência parcial, incrementa a circulação de ar e luz, substâncias vitais dos lugares, e muitas vezes raras. Na direção oposta dos grandes muros cada vez mais frequentes que retomam a idéia de fortificações e isolam casa e cidade, visíveis nas grandes concentrações urbanas no Brasil e sobretudo em São Paulo.

Outro equipamento urbano de uso corrente nos bairros residenciais ou comerciais, é a grade metálica, de infinitos formatos, padrões, funcionamento. Neste caso o isolamento visual não é completo, como nos muros e paredes de alvenaria, pois há uma transparência relativa que permite que o prédio ou casa permaneçam visíveis na paisagem cada vez mais congestionada de camadas sobrepostas.

Grades são usadas tanto em residências luxuosas quanto nas mais pobres, nos prédios enormes e nas casas mínimas. O que suscita a grande variedade de desenhos nestas grades é o mesmo desejo de diferenciação do entorno, que na prática corrente das customizações, produz a enorme diversidade de cores e materiais de revestimento em fachadas nas ruas de SP. A vontade de diferença encontra um terreno favorável no grande potencial gráfico das grades, chapas perfuradas, malhas metálicas, e cada portão parece um exercício de criatividade empenhado em obter o máximo de efeito visual e originalidade.

A idéia do projeto "Stand", veio da observação destas grades e mecanismos em portões de garagens e casas: transformar portões em paredes que estão constantemente abrindo e fechando e programar os motores "coreografando" estes movimentos. A forma e as dimensões foram definidas diante do espaço arquitetônico (área externa ao Pavilhão da Bienal de SP) e do contexto da Feira da qual faria parte. 


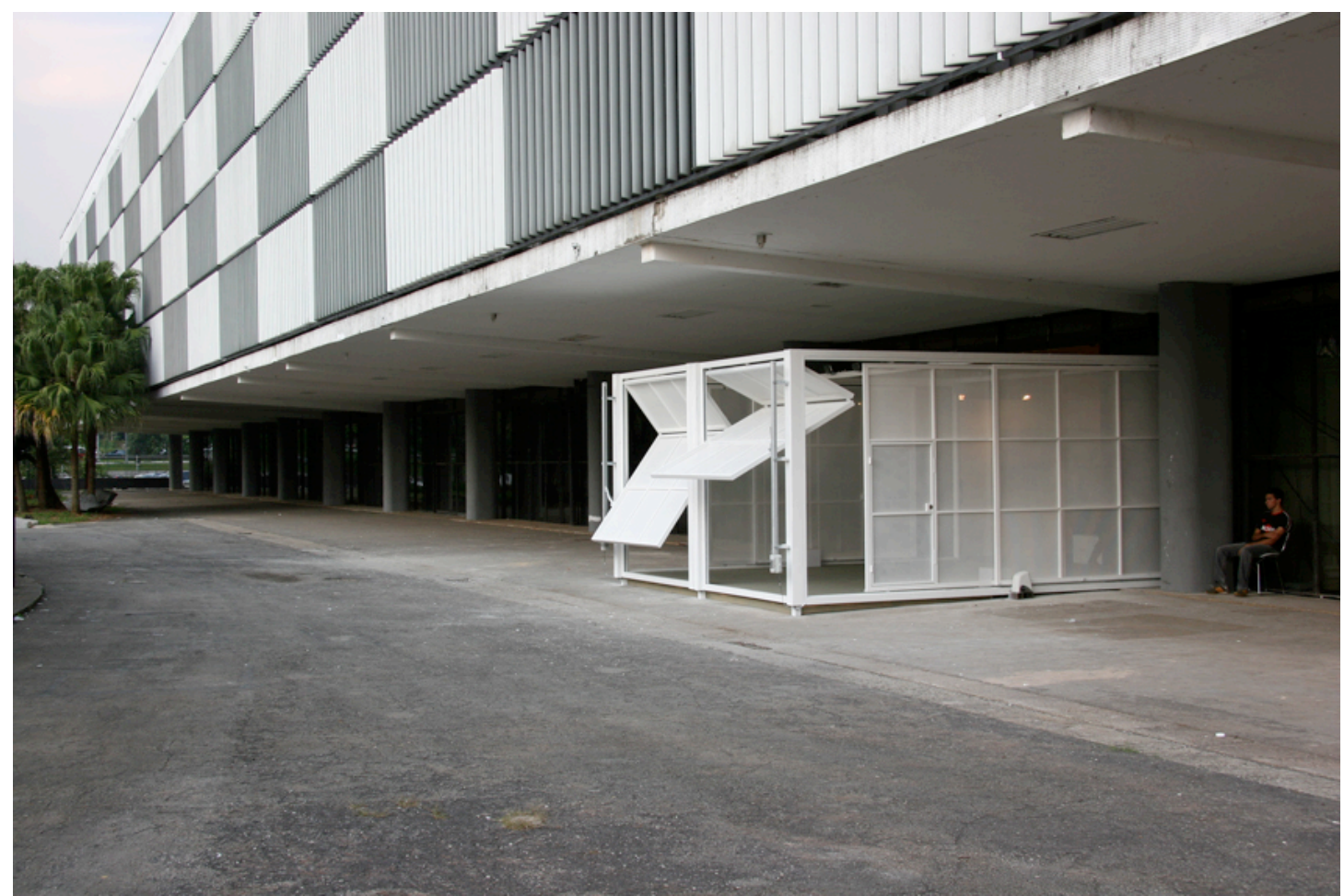

Stand 2007 - chapa de metal perfurada, estrutura metálica e motor

Stand foi um projeto comissionado por empresa patrocinadora da $2^{\mathrm{a}}$ edição da SPARTE - Feira de Arte, que teve lugar no Pavilhão da Bienal de São Paulo. O espaço disponível para o projeto era contíguo a uma das portas (saídas de emergência) laterais que dão acesso ao parque Ibirapuera. O ambiente que construí ali foi chamado Stand porque era uma extensão da feira de arte, e tinha as dimensões de estande médio, paredes brancas. Só que vazio de obras de arte.

Sala construída com portões automáticos programados para moverem-se a cada dois minutos, abrindo e fechando, correndo umas sobre as outras. Ficava visualmente acoplada ao prédio, "encaixada" em suas portas, com uma das faces completamente aberta. E tinha também as dimensões de uma garagem para dois carros. $E$ foi montada por uma empresa de portões, com os materiais, estrutura e motores habitualmente usados na fabricação e instalação destes portões automáticos. 


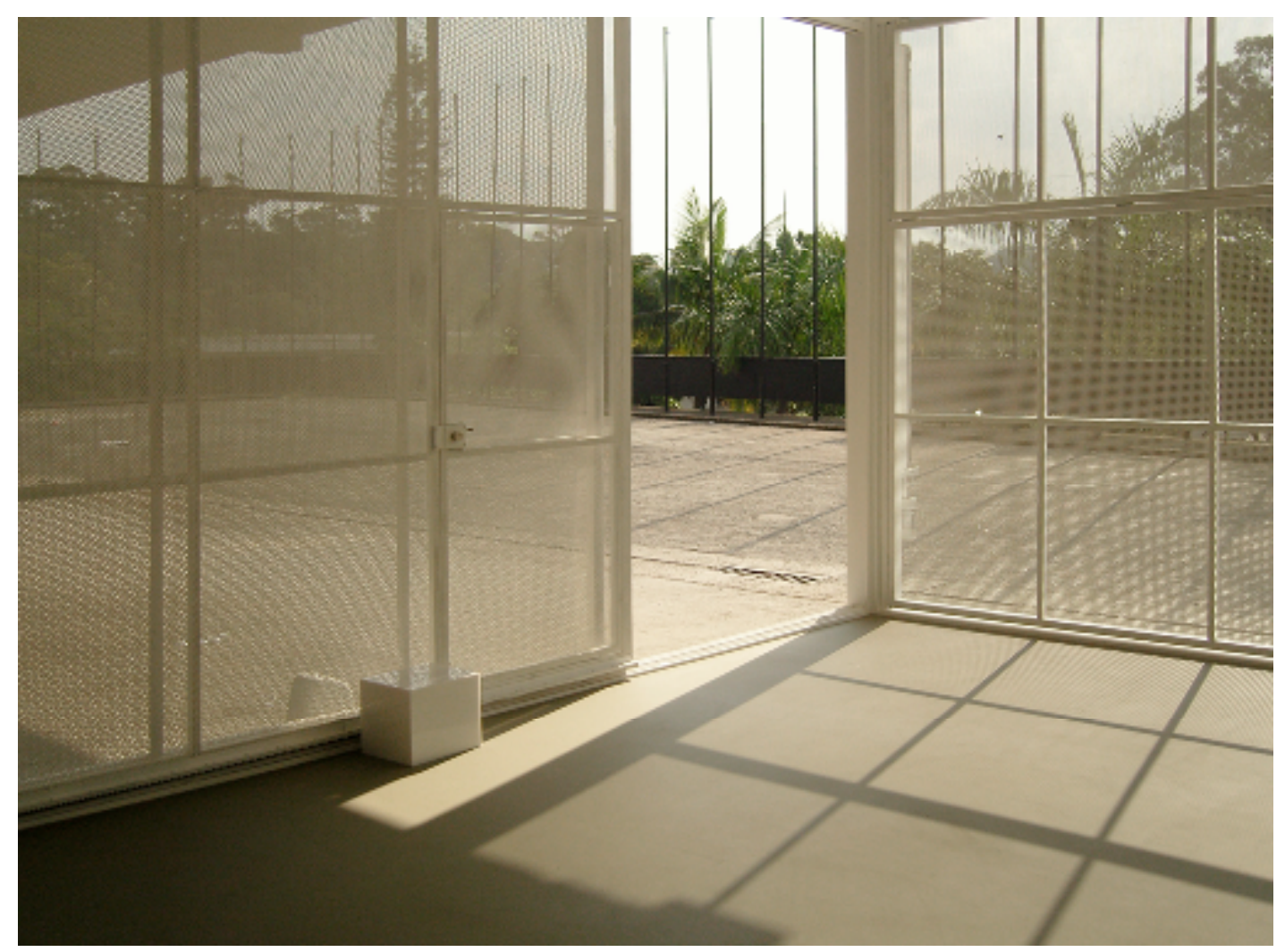

Stand-paredes deslizantes e basculantes em movimento

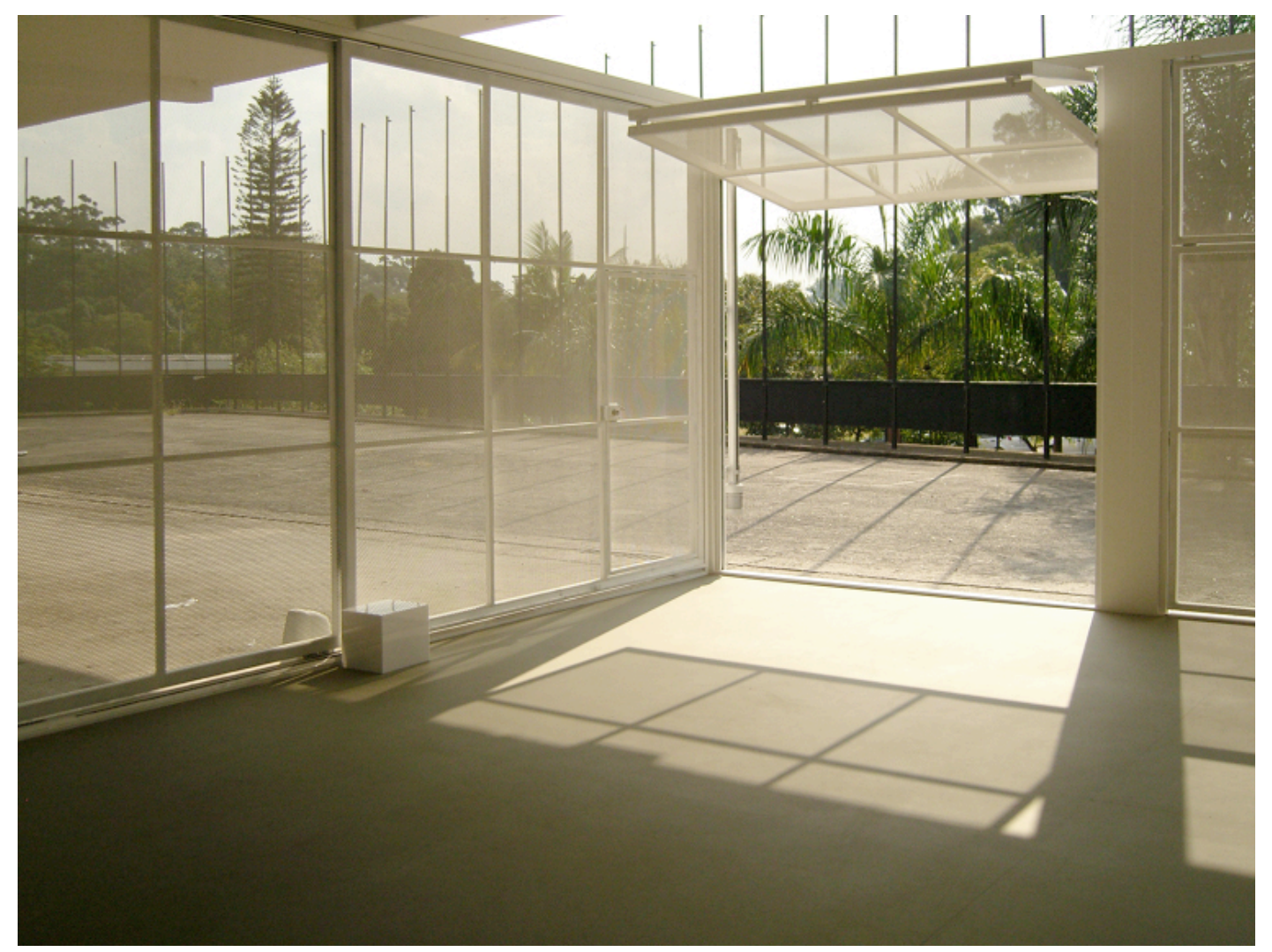


As paredes em movimento foram livremente inspiradas no princípio de painéis deslizantes usados por El Lisstky em seu "Gabinete da Abstração". Nesta obra que antecipava a criação de "ambientes para arte" como prática do artista, muito presente na produção contemporânea, as obras de outros artistas eram exibidas em estruturas de trilhos, fixas as paredes, ou em nichosvitrine. Os planos deslizavam, cobrindo ou revelando as pinturas ali expostas. A complexidade deste exercício construtivo está na variedade de configurações possíveis do espaço de relações entre as obras, sujeito e espaço.

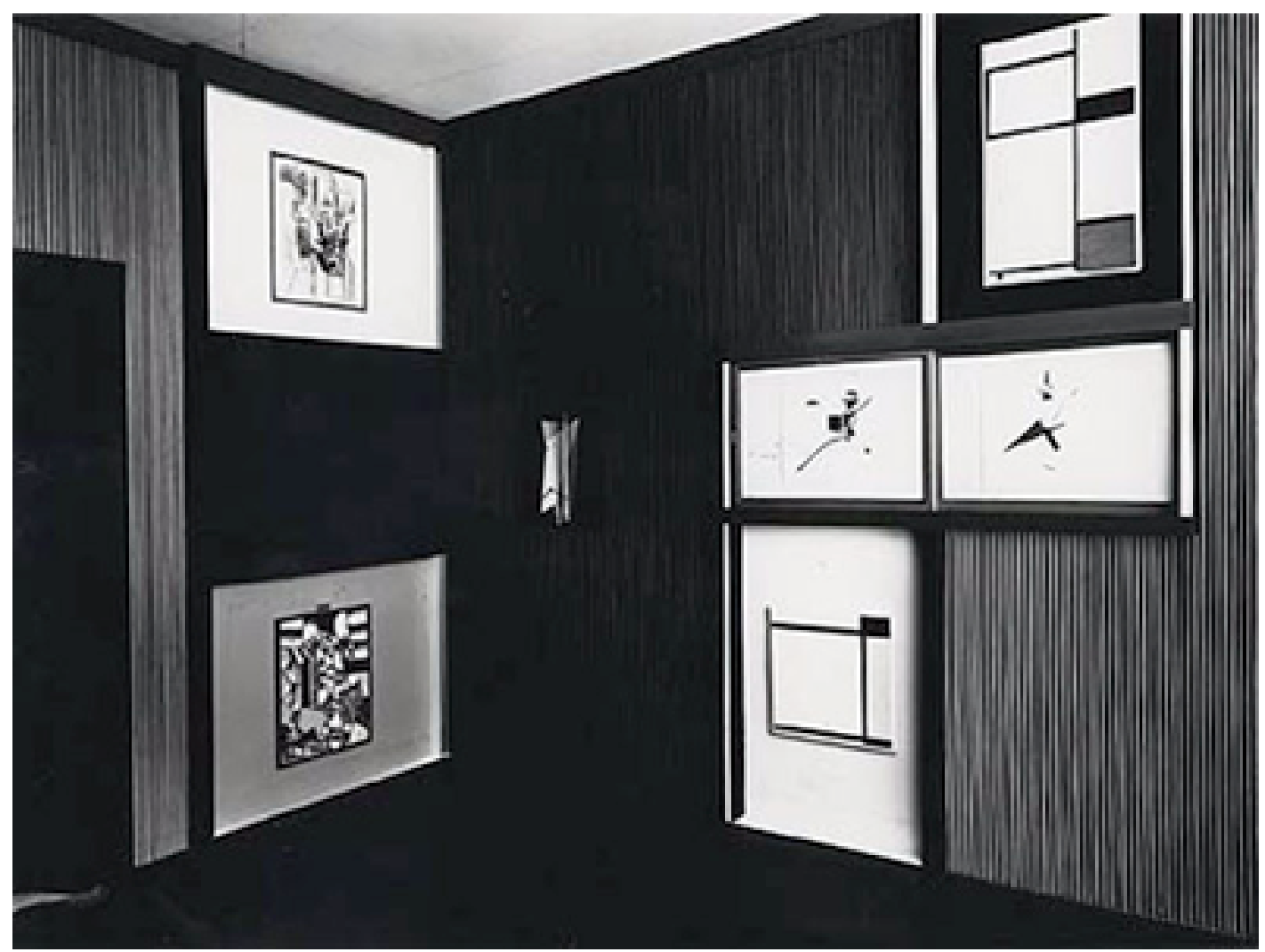

El Lissitzky, Kabinett der Abstrakten (Gabinete da Abstração), 1928. Esta reconstrução feita 1968, pertence a coleção do Sprengel Museum em Hannover, onde está em exposição permanente desde 1979.

Mas no Stand não havia obras expostas, e os movimentos programados aconteciam a despeito da vontade do visitante. O efeito produzido pela sobreposição é o de uma perturbação visual. 


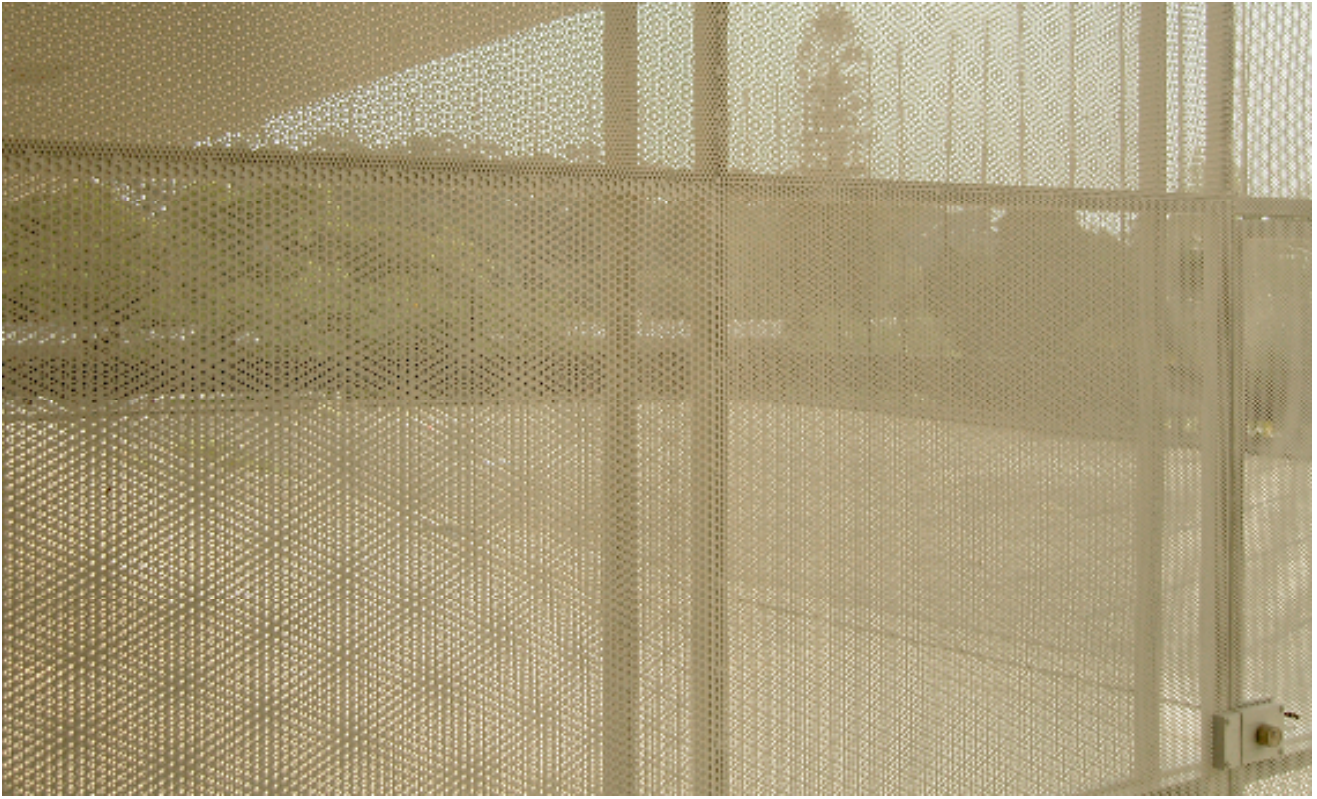

Os painéis são feitos com chapas de metal perfuradas em sete diferentes padrões de furos circulares simples, que multiplicavamse com o movimento de um painel sobre o outro, formando novos padrões em combinações imprevisíveis e aleatórias uma vez que não havia como controlá-las.

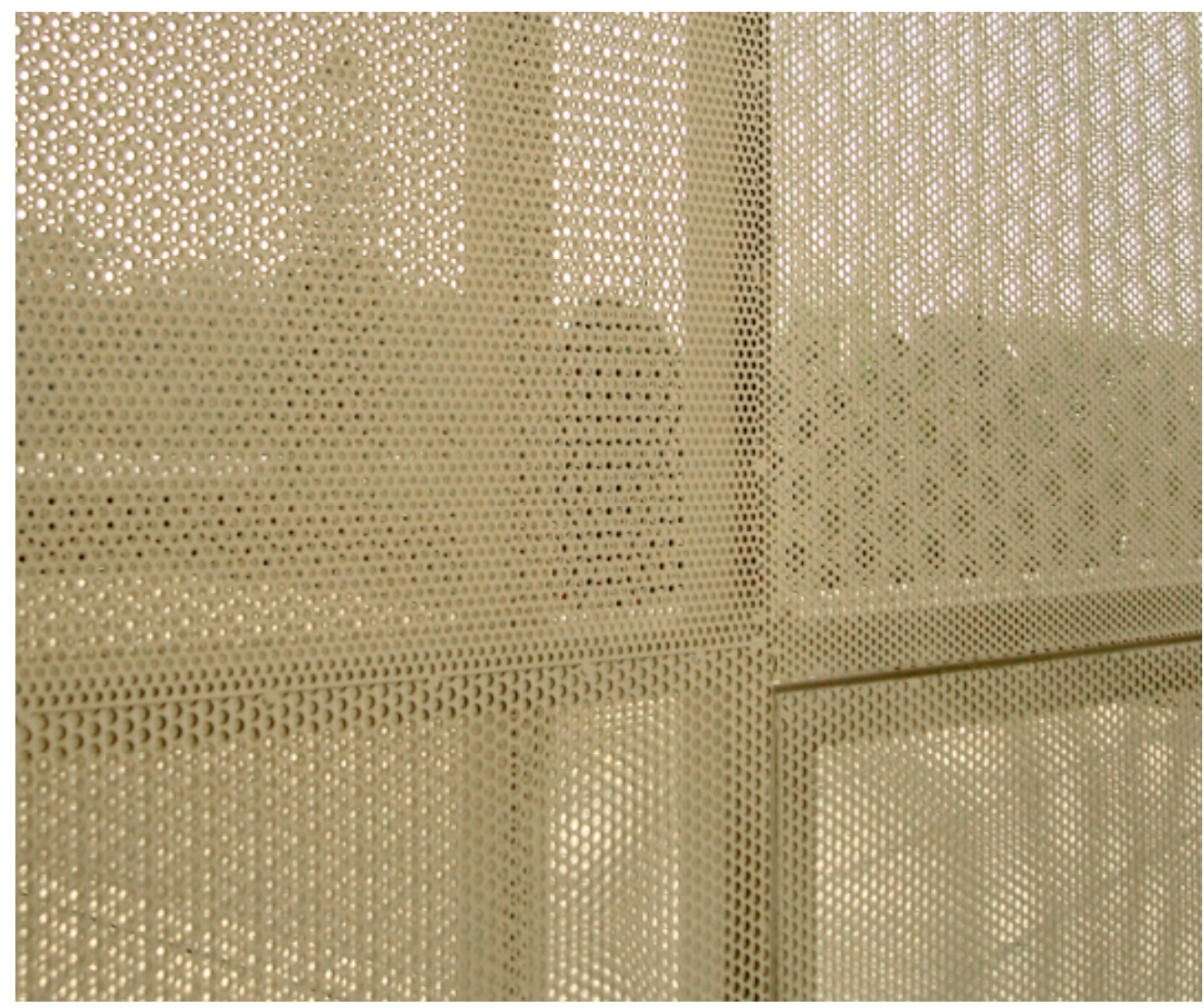


A cada doze minutos a sala se recompunha, com suas paredes todas em repouso momentâneo, para recomeçarem em seguida a abrir e fechar. O visitante podia assim sair e voltar, experimentar a visão externa na qual a sala como objeto arquitetônico e sua conexão com o prédio eram mais evidentes. O olhar podia inclusive atravessar a sala, cruzando mais camadas, e encontrando novos moirés.

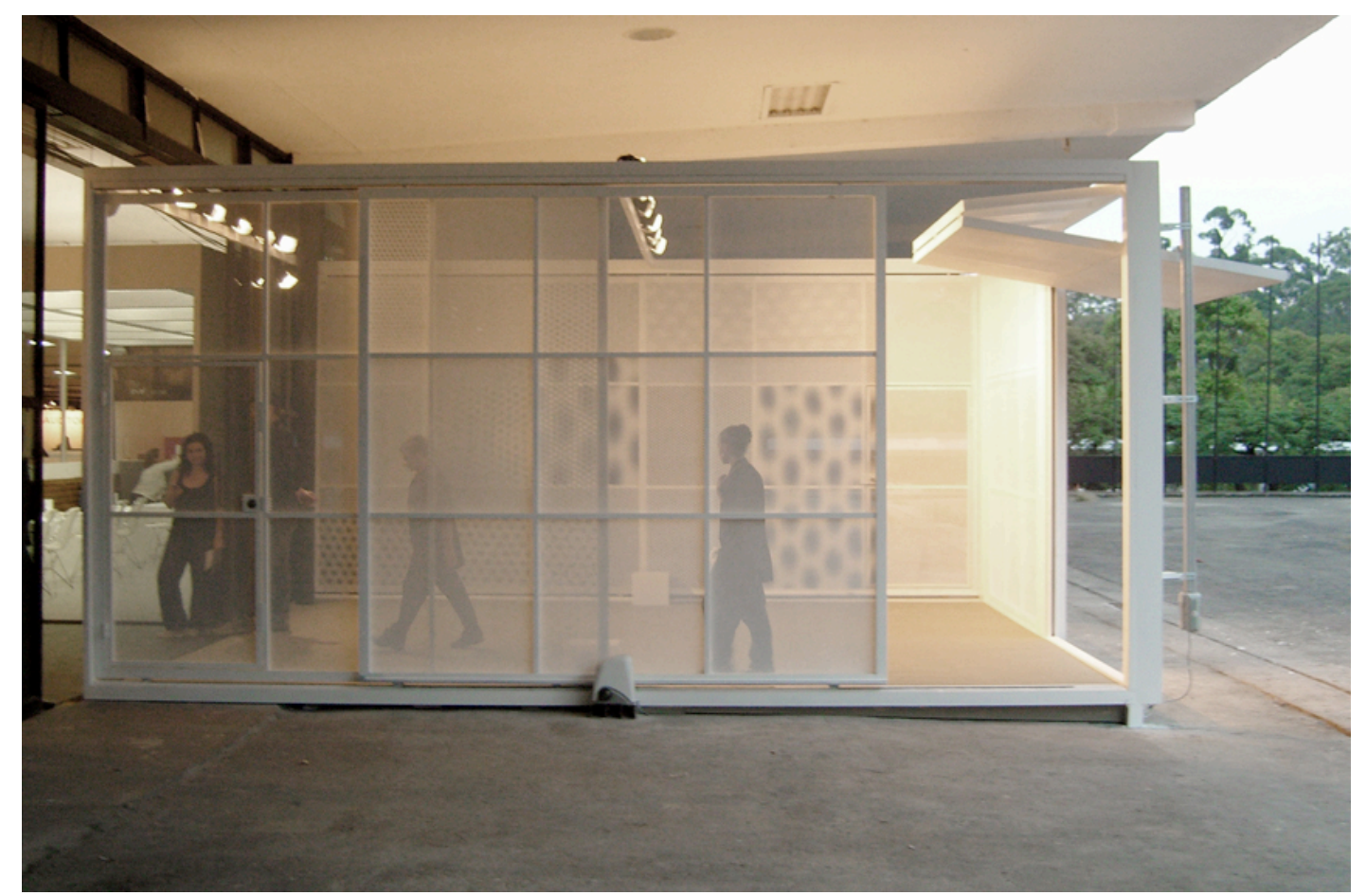

Stand - ponto de vista externo ao entardecer

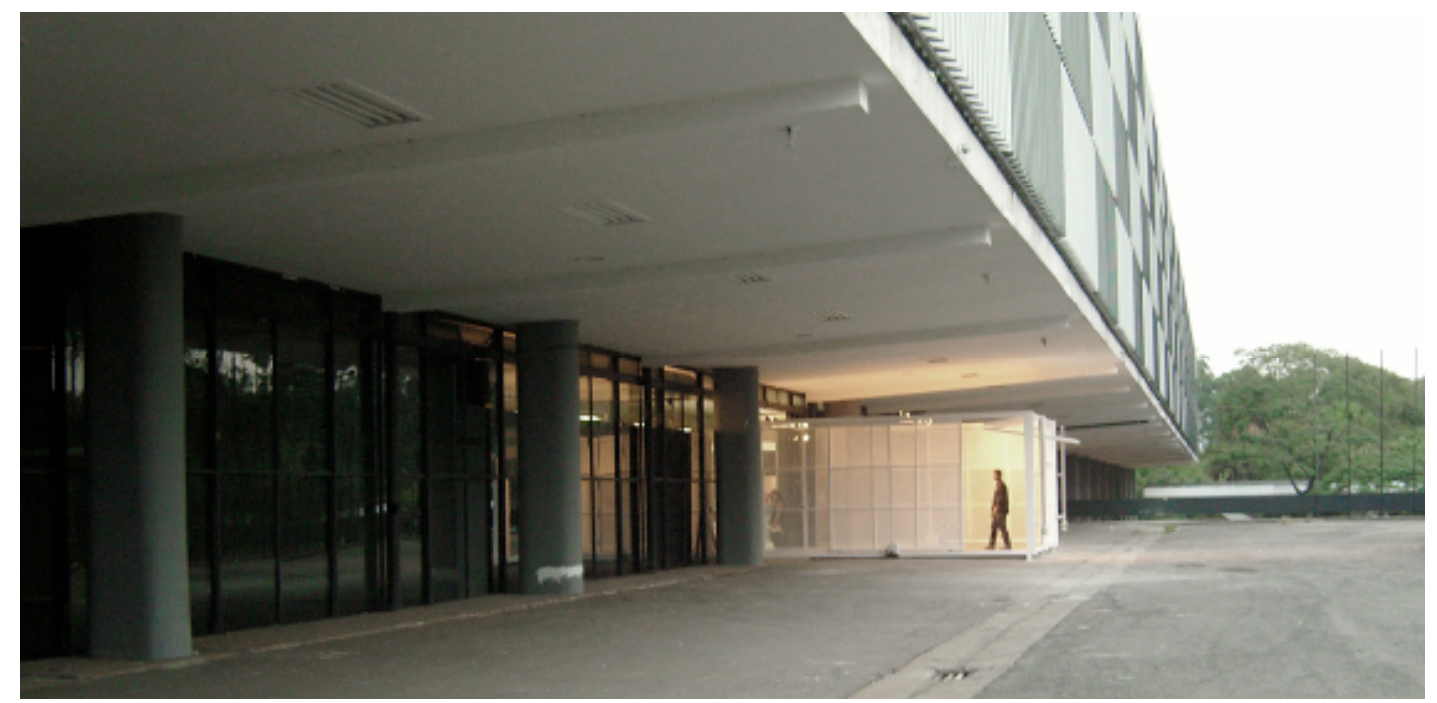




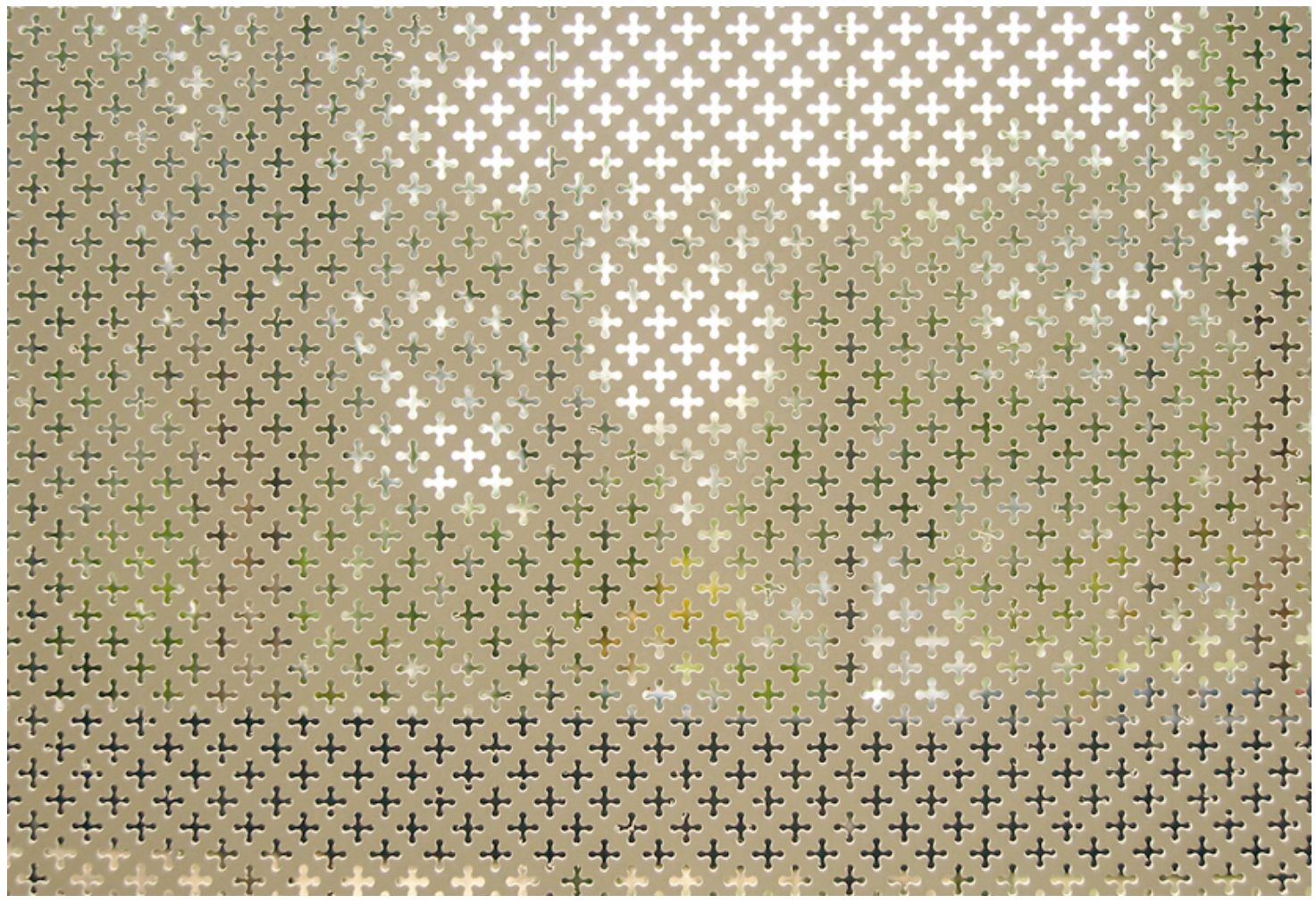

A história das transformações culturais e especificamente arquitetônicas é feita com o encadeamento de influências, uma vez que as linguagens são coisas vivas que se definem pelo uso e por isso mesmo não cessam de adaptar-se. A arquitetura popular importa como fonte por sua inevitável atualidade, pois processa os fatos arquitetônicos já experimentados em outros contextos, na prática de construir+habitar (indissociáveis aqui) obrigando-se a pensar o espaço de relações em que vivem seus autores, nas infinitas adaptações que mantém as construções abertas. A idéia de que uma construção está sempre incompleta a converte em espaço de projeção que é gerador de sentido. 


\section{Proximidade, Colaborações e outros ATRITOS - a experiência na $27^{\text {a }}$ Bienal de São Paulo}

Embora grande parte dos artistas acredite que as melhores condições para exporem seus trabalhos são as de um espaço de exibição (supostamente) neutro, são cada vez mais presentes aqueles dispostos a deixarem-se afetar pelo lugar, pelas especificidades do contexto. Não apenas assumem que espaços institucionais ou comerciais não são neutros jamais - justamente porque constituem o discurso de um programa de intenções - mas também evitam a idéia mesma de neutralidade e tomam o lugar como ativador de sentido para seu trabalho.

A recusa da neutralidade do espaço da arte se refere não apenas ao espaço arquitetônico original ou suas adaptações temporárias, mas a teia de relações que se estabelece entre os profissionais envolvidos a cada exposição. Grandes exposições coletivas são na verdade terrenos de alta tensão nas relações entre os artistas ocupando um espaço, experimentando uma espécie de co-autoria que costuma ser involuntária. Também a relação entre as obras e o discurso da curadoria oficial, que pode variar da mera ilustração à efetiva colaboração e mútua influência, é tencionada em seus muitos pólos e impregnada de um sentido que se revela na disposição das peças e salas, no desenho dos espaços da mostra. Estas relações são expressas assim, na linguagem da arquitetura, esta arquitetura provisória de ocupação do espaço com painéis, nichos e salas construidos para cada exposição.

Mas se os artistas respondem com a linguagem da arquitetura, podem falar destas relações, ou reconduzi-las, desestabilizá-las. Esta é a proposição em "Sala de Exposição", projeto criado para a $27^{a}$ edição da Bienal de São Paulo. 


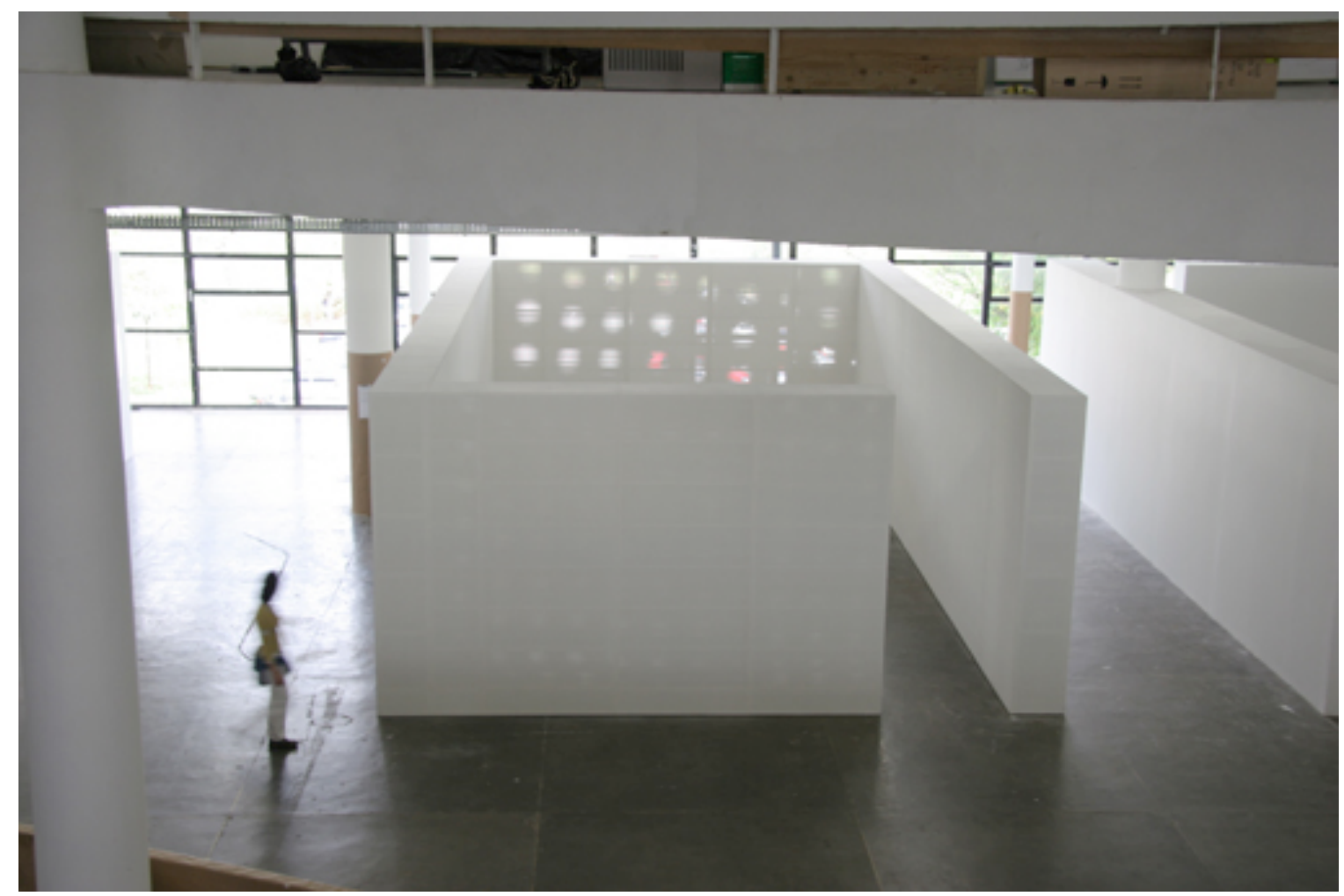

"Sala de Exposição", 2006

Sala de Exposição ${ }^{26}$ foi importante também como exercício de reconfiguração de um trabalho realizado em 2001 para o Panorama da Arte Brasileira do MAM em São Paulo. Os "Painéis-filtro" construídos no mesmo material eram também anexados ao projeto expositivo da mostra, criando um vazio e uma certa perturbação visual no lugar da apresentação de uma obra. Naquela ocasião já pude experimentar várias configurações de paredes pois a mostra itinerou pelos museus de Arte Moderna de Salvador e do Rio e em cada um deles, como mudava o desenho do espaço expositivo, mudava também o desenho das paredes perfuradas. A adaptação deste trabalho parecia fazer sentido no contexto da Bienal, uma grande exposição com longa tradição no universo da arte brasileira e no circuito internacional, onde os modos de exibir e ver são sempre questões ativas e tem um público ampliado.

\footnotetext{
${ }^{26}$ Na pesquisa de imagens e informações sobre "O Gabinete da Abstração", de El Lisstzky, referência apresentada no capítulo anterior, descobri que o Gabinete era parte de uma série de projetos seus entitulados "Salas de Exposição".
} 


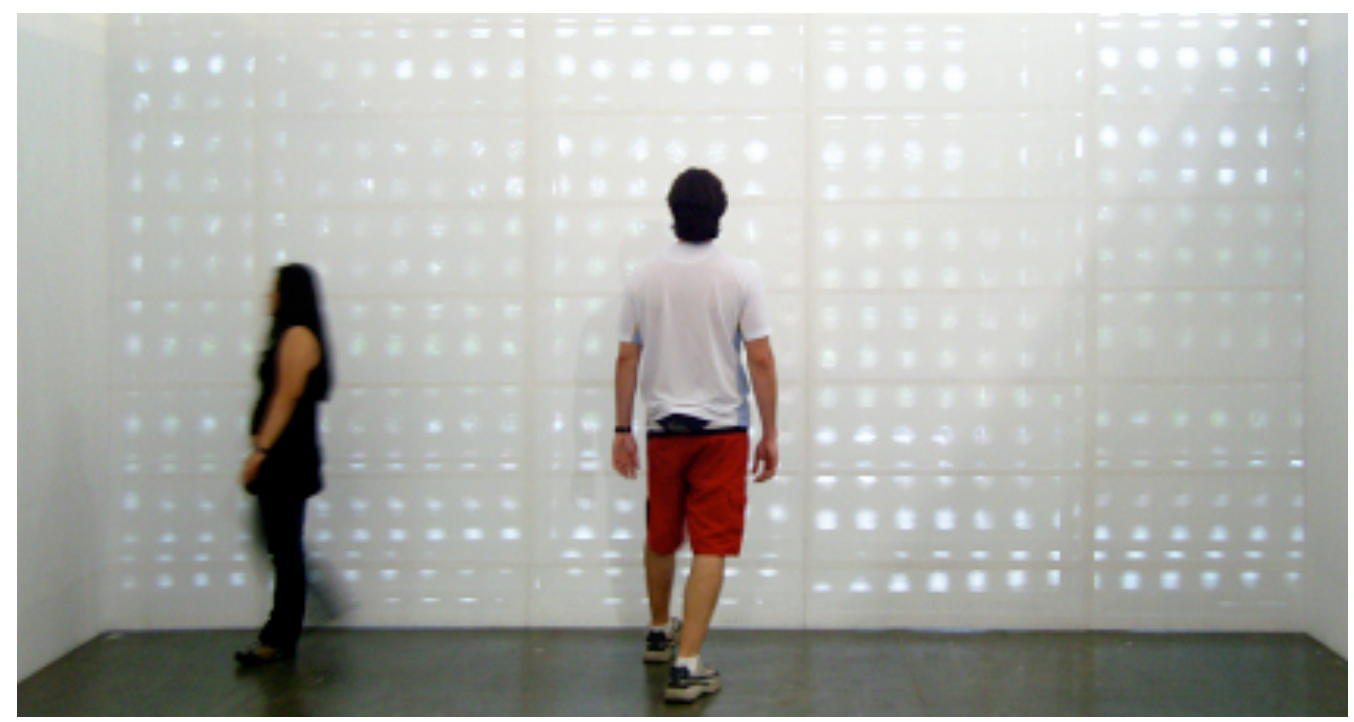

O efeito de moiré causado pela sobreposição de duas camadas perfuradas a uma certa distância, era cambiante: a grade de circulos virtual que se formava quando a parede ela atravessada pela luz, mudava de escala de acordo com a distância do observador. Assim, quando ele se movia para frente/trás ou para os lados, alterava tamanho e posição destes circulos. O observador descobria isto entrando na sala e experimentando aproximação e recuo, caminhar em diferentes velocidades, ajustes de foco, etc.

A distância entre as camadas, ou seja, a espessura da parede, era a mesma dos demais painéis da exposição. Para o trabalho operar como uma idéia de alteração de uma sala da Bienal, era fundamental encontrar um denominador entre os espaços projetados para a mostra, uma "sala-tipo". Como não havia um modelo adotado para todas as salas, o desenho de Sala de Exposição deduz uma "sala-tipo", e apenas os materiais empregados são diferentes. As dimensões e o desenho da abertura eram replicados das salas vizinhas (de Leon Ferrari e Felix Gonzales Torres), e o pé-direito idêntico ao dos espaços ao redor. Foi desenhada em colaboração com a arquiteta Marta Bogéa, responsável pelo projeto arquitetônico desta edição da Bienal, sempre muito disponível as desetabilizações e problemas inventados. 
Propor também co-autorias, experimentando assim as negociações e continuidades que necessariamente acontecem quando dois artistas trabalham juntos num projeto, foi outra forma de responder aos problemas propostos pela curadoria desta edição da Bienal, obrigando-a a adaptar sua estrutura de produção e modos de operar. Os projetos de colaboração realizados foram "Un buen orden", com o artista mexicano Hector Zamora e a "Parede-favo" que substituia uma vidraça criando uma entrada de ar na sala de Jarbas Lopes. Jarbas já havia projetado seu trabalho como uma experiência coletiva, convidando outros 11 artistas a percorrer o Rio Amazonas e trazer os vestígios desta expedição para o espaço destinado a seu trabalho na Bienal, e propôs que eu me integrasse ao projeto no momento de sua apresentação.

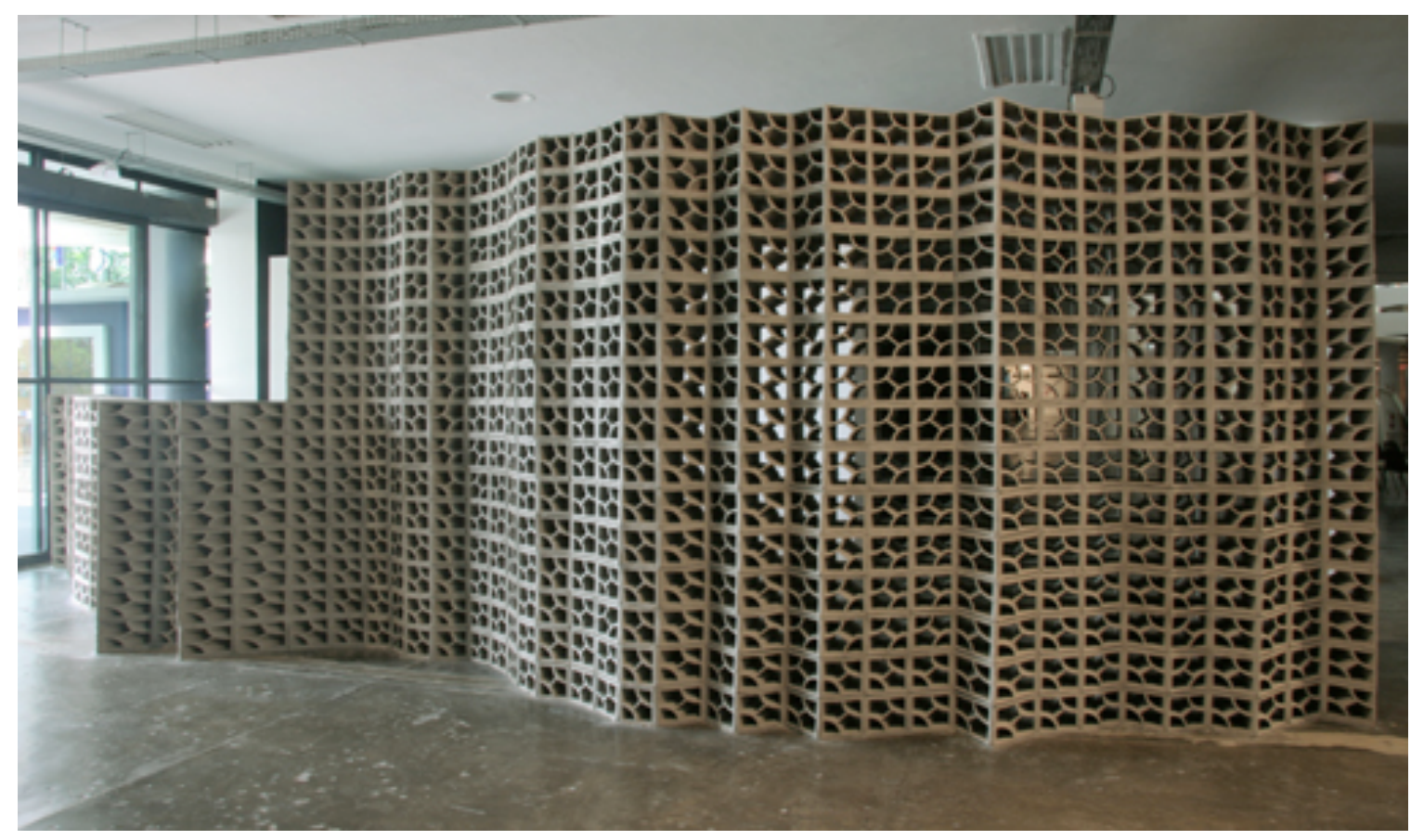

"Un buen Orden" (com Hector Zamora) 27ª Bienal de São Paulo, 2006

No primeiro caso, da colaboração com Hector Zamora, houve uma simetria entre os artistas nas relações e processos, desde os conceitos e modos construtivos essenciais até as escolhas menores, também definidoras do trabalho que apresentamos. A idéia de uma parede auto-portante que sugerisse ainda um modo de 
crescimento orgânico e aleatório, foi se acrescentando uma função de obstáculo semi-transparente a medida que a localizamos ao final da larga rampa de acesso do $1^{\circ}$ piso, cobrindo sua extensão. Com intervenções na produção das peças cerâmicas, customizando espessura, ângulos de corte e acabamento feitos na fábrica, não apenas asseguramos a sustentação da parede, mas a possibilidade de zig-zags e curvas que tornavam mais complexa sua estrutura visual, alternando padrões a partir de um único módulo.

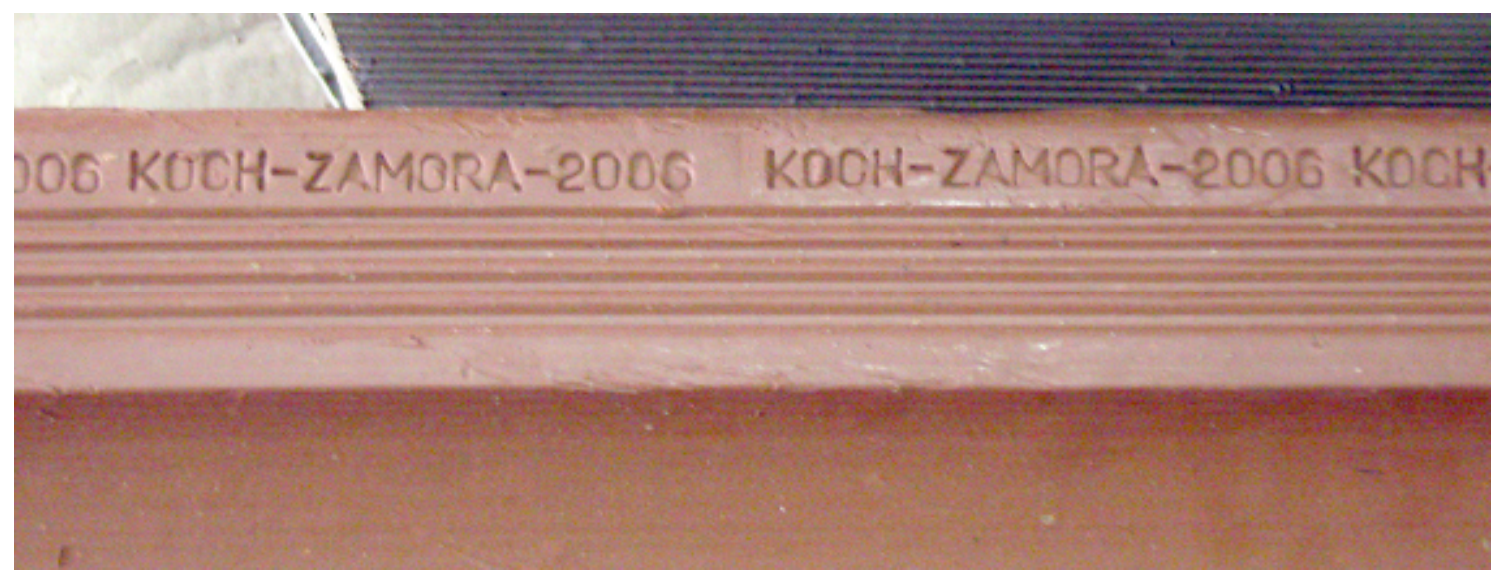

as peças modificadas na fábrica foram assinadas como registro de nossa intervenção.

a profundidade usual das peças é de $7 \mathrm{~cm}$ e produzimos peças com $38 \mathrm{~cm}$; além dos ângulo de $90^{\circ}$ e $45^{\circ}$ disponíveis no mercado usamos peças de $30^{\circ}$ e $60^{\circ}$

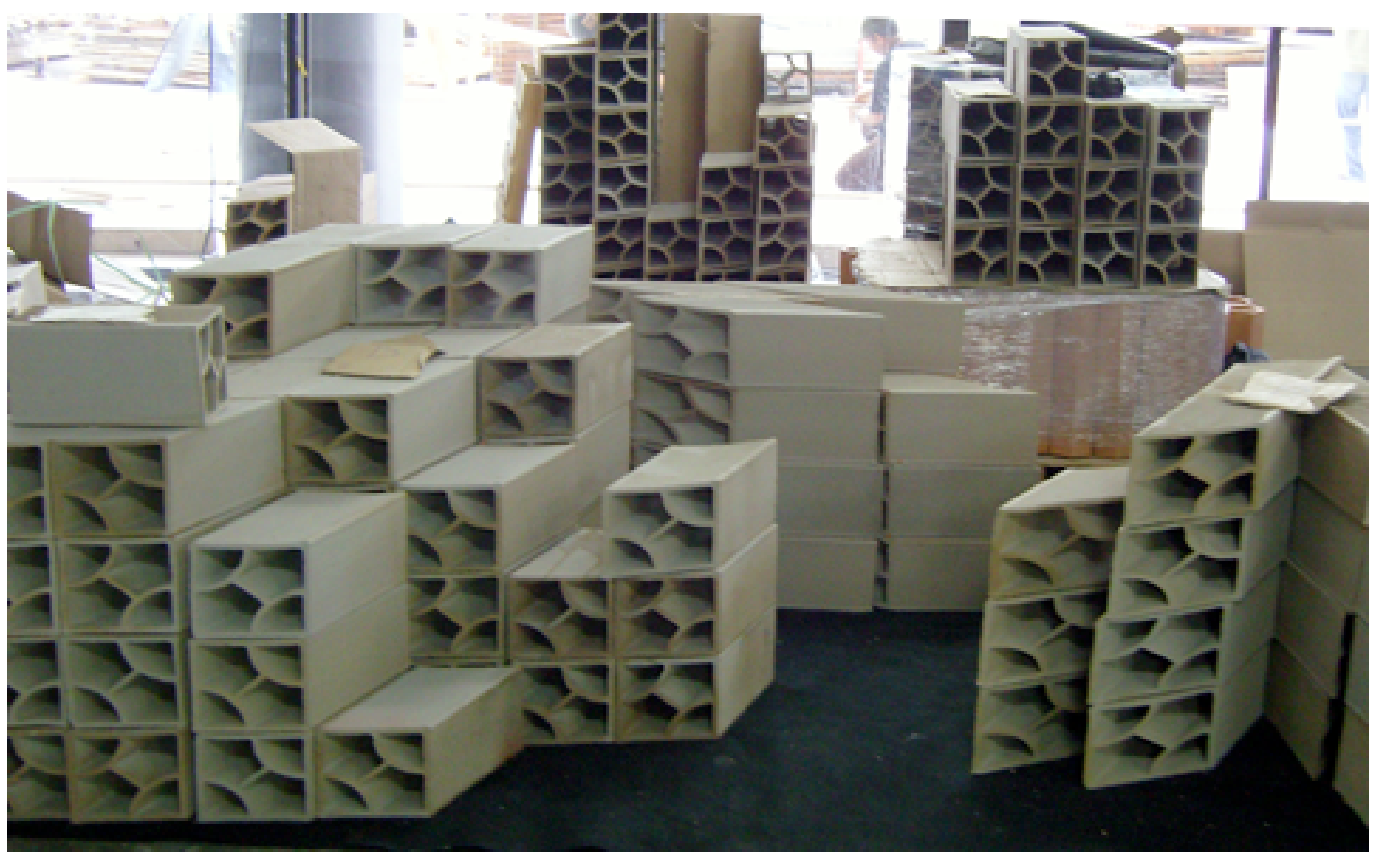


Com Jarbas Lopes o processo foi de outra natureza pois atuamos separadamente, num mesmo espaço mas em momentos diferentes. Jarbas sugeriu como modo de colaboração, que a sala fosse preparada por mim para recebê-los na volta de sua expedição, usando elementos vazados cerâmicos e construindo estruturas que abrigariam os materias coletados e transportados desde o rio Amazonas. A idéia era: chegando ao seu espaço na Bienal os artistas viajantes adaptariam-se a sua conformação, respondendo diretamente a esta primeira intervenção.

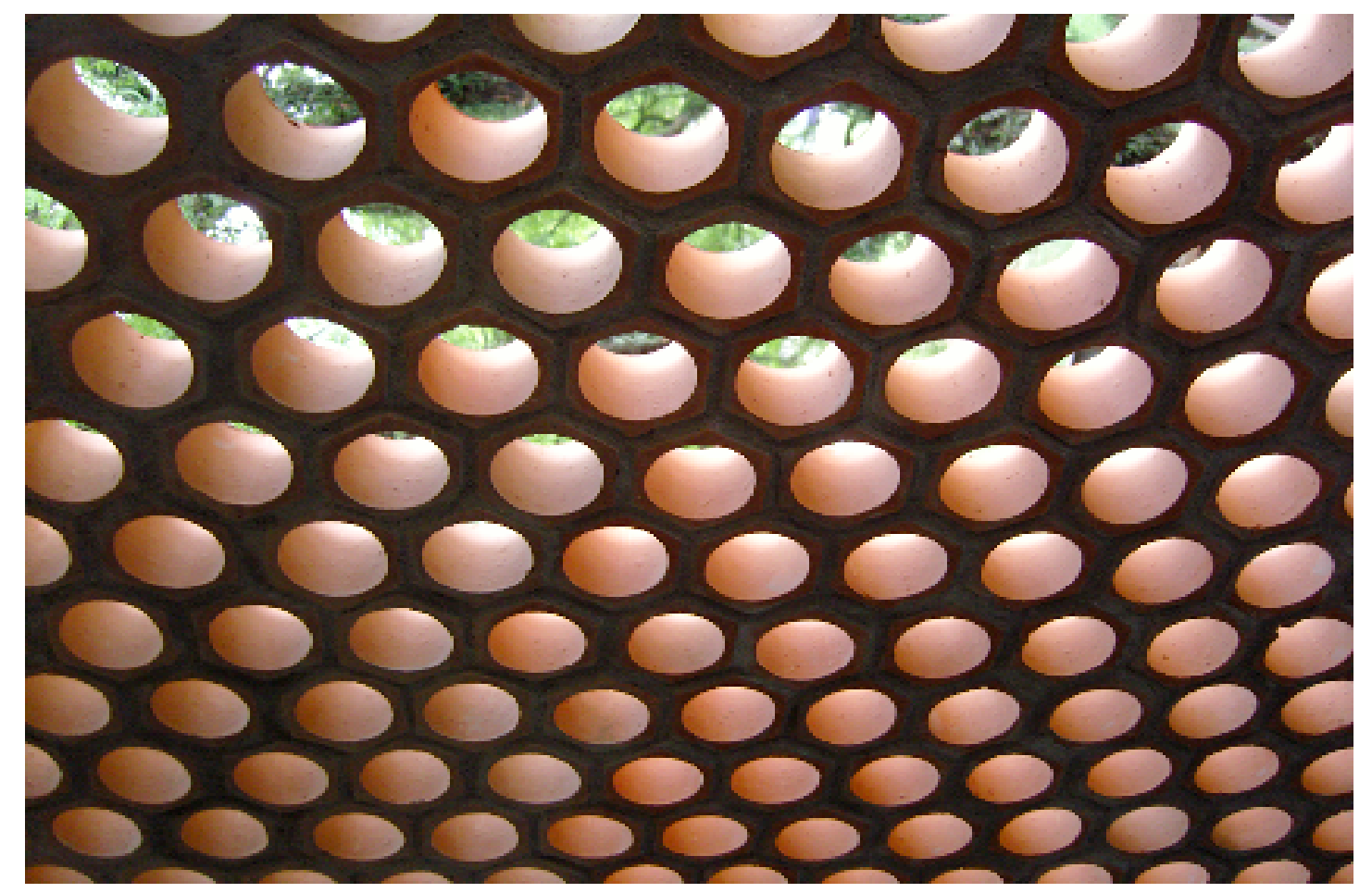

"Parede-favo" colaboração com Jarbas Lopes, para a $27^{\text {a} B i e n a l ~ d e ~ S a ̃ o ~ P a u l o ~}$

Como a parede-favo foi colocada no caixilho de uma das janelas da qual os vidros foram retirados, a ventilação que ela proporcionava era muito sensível, a troca de ar, as folhas e flores da árvore vizinha sopradas para dentro da sala. Os artistas acabaram montando ali uma tenda improvisada, assim como haviam feito em sua viagem pelo rio, e dormiram algumas noites na sala de exposição. 
A parede-favo tornava a sala permeável ao parque, ali circulavam luz e ar. Esta "troca de pele" fez o lugar respirar melhor e com isso também criou um foco de domestificação do espaço, tornou-o habitável. Cobrir a parede-favo com plasticos e tecidos, ao contrário de escondê-la, deu a ela uma função mais evidente: tornava o ar que a atravessava visível, com efeitos variados ao longo do dia, da agitação barulhenta do vento no plástico ao movimento mínimo de uma pulsação tranquila. E a ocupação deste espaço como lugar de repouso dava sentido a intervenção temporária feita na arquitetura.

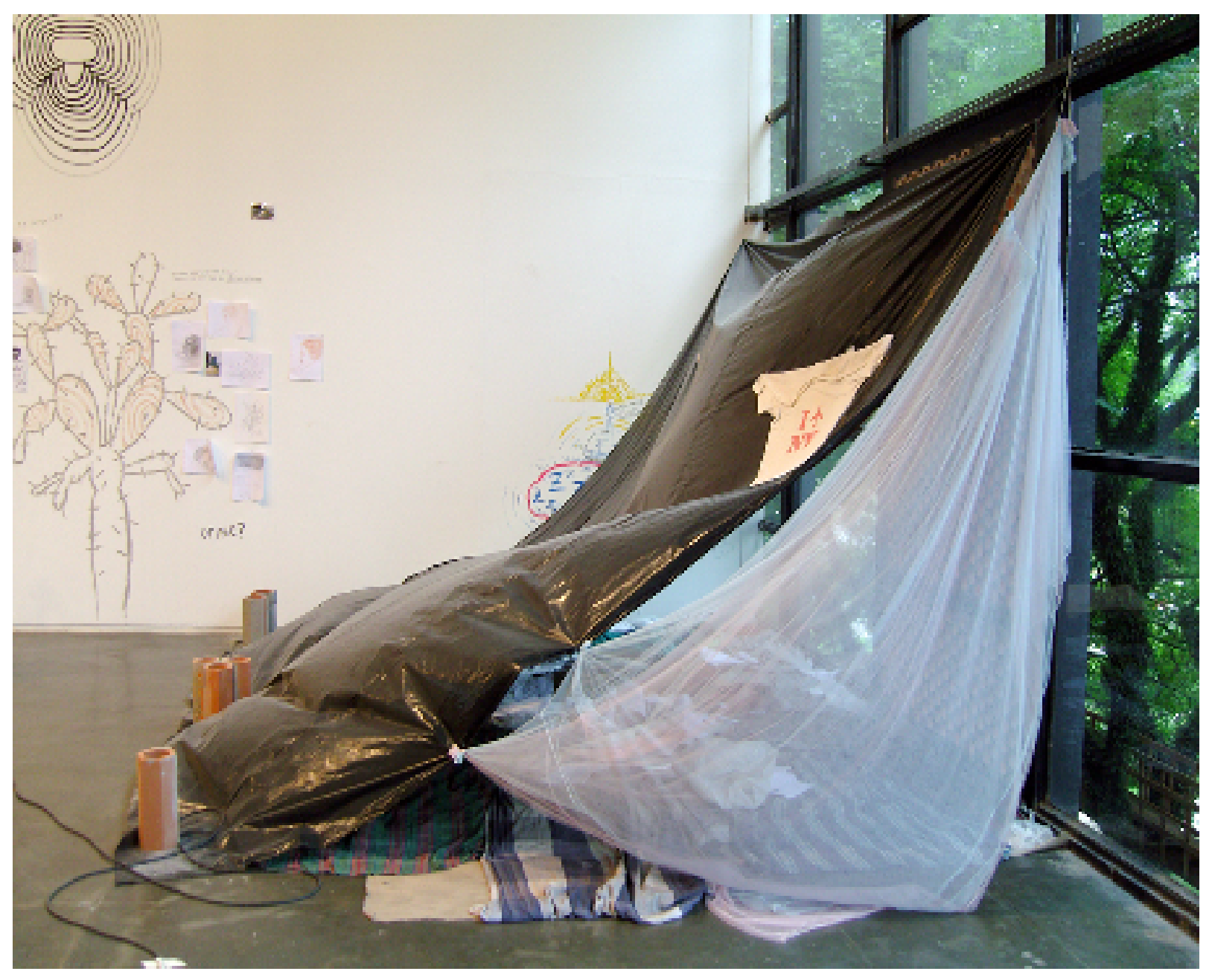

Tenda montada pelos artistas da expedição de Jarbas Lopes em frente a parede-favo, quando chegaram da Amazônia e "desembarcaram" no pavilhão da Bienal de São Paulo, e ocupada por eles nos dias que antecederam a abertura da exposição. 
Mas Sala de Exposição pareceu ser a transformação mais efetiva e mimética entre os projetos apresentados na $27^{a}$ Bienal. Os códigos e funções que habitualmente orientam a construção dos espaços mostras como a Bienal foram empregados na construção de uma pseudo sala-tipo com algumas alterações essenciais.
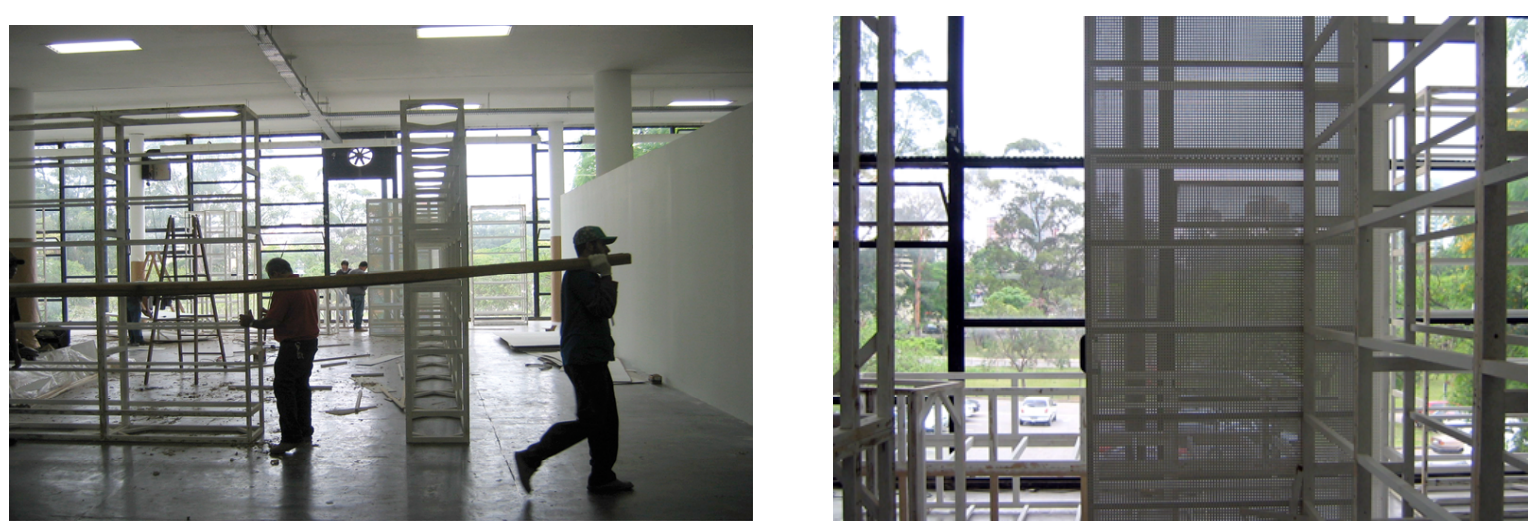

As paredes foram construídas com chapas perfuradas que as tornavam transparentes e vazadas, permeáveis ao ar e a luz. O que causava perturbação na sala vazia, com a ausência de obras, era potencializado pela vibração que viamos nestas paredes. 

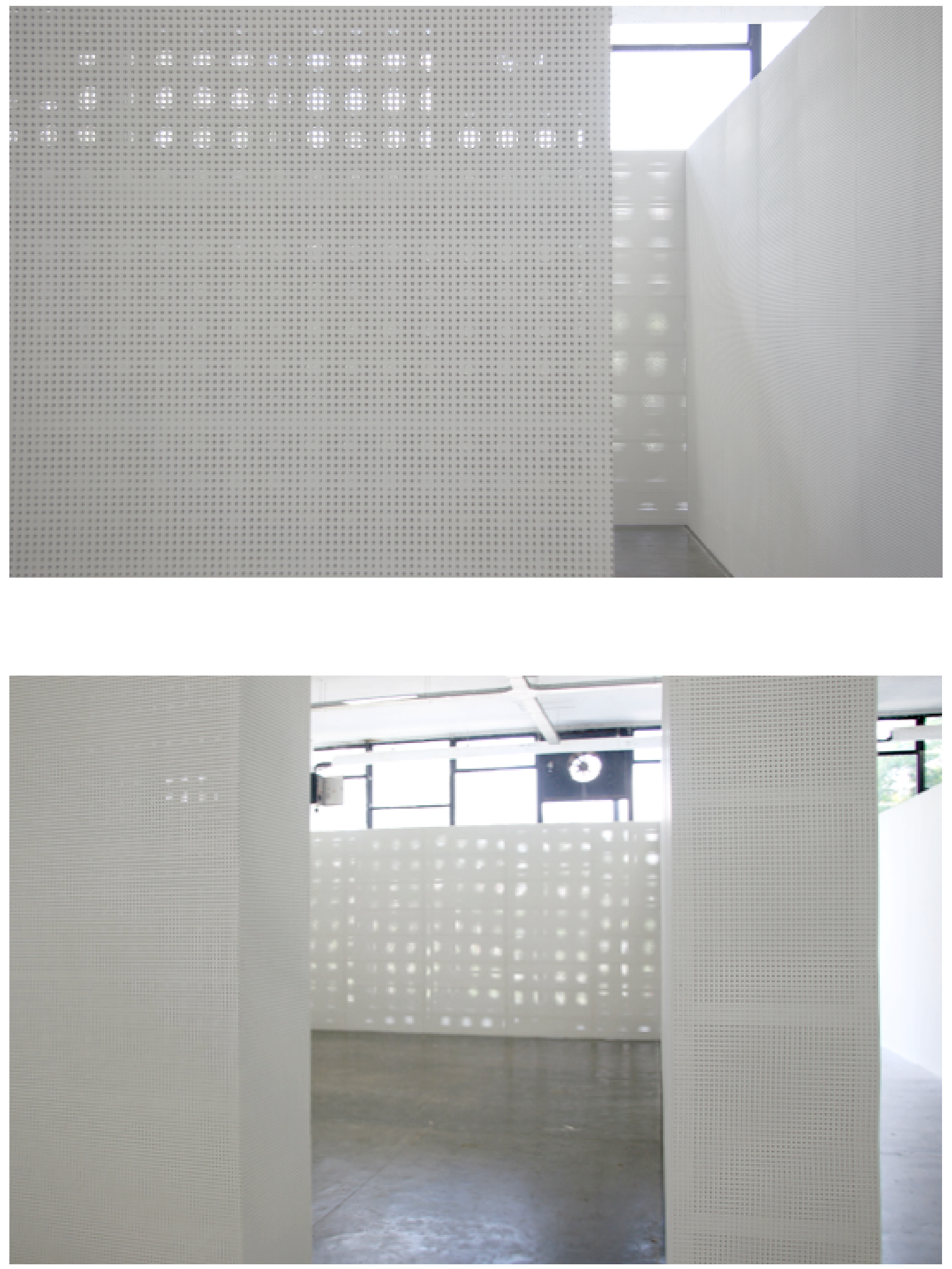


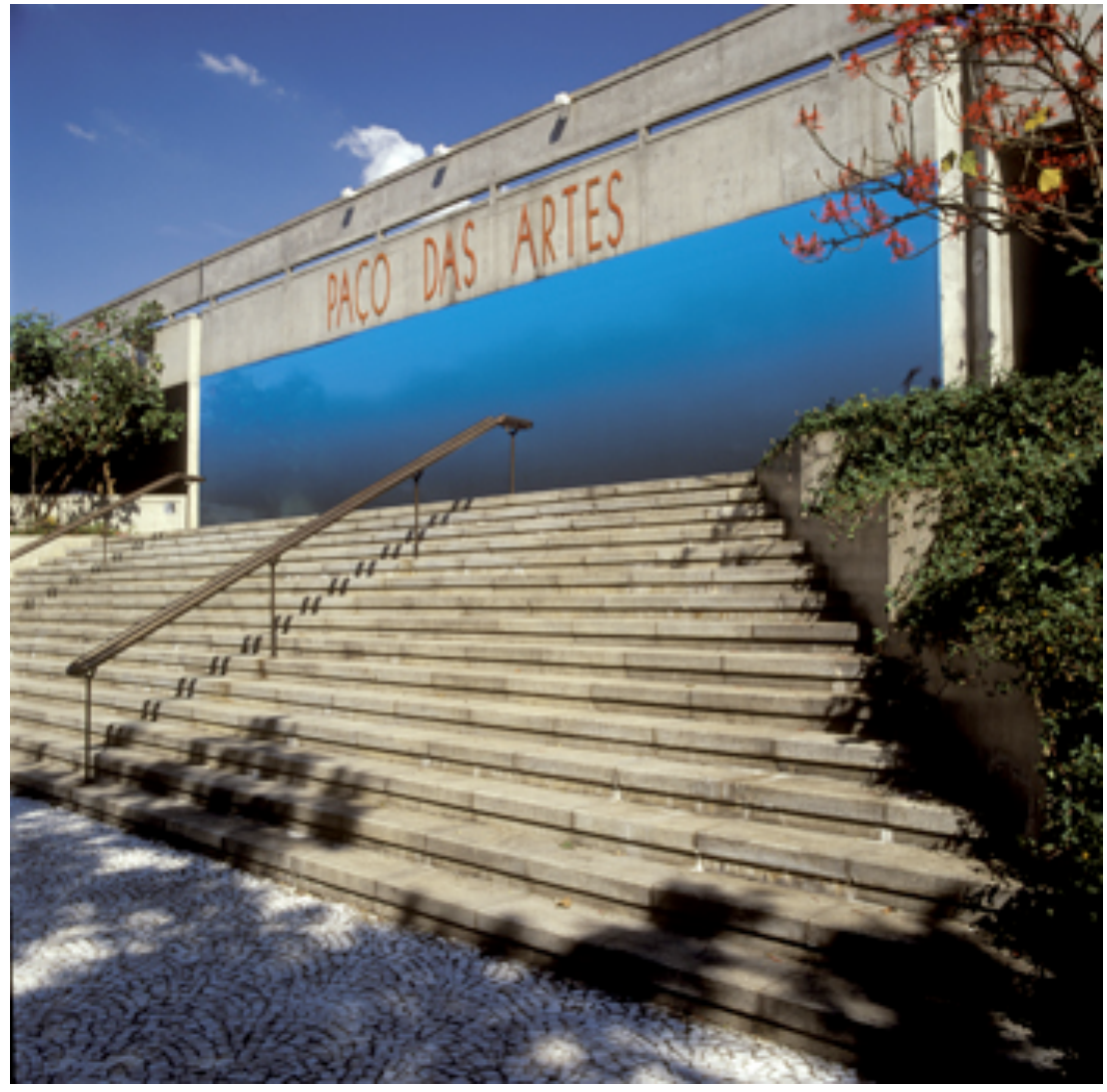

DEGRADÊ SP - Paço das Artes, São Paulo, 2004

\section{DEgRADÊS: REDUÇÃO, ADAPTAÇÃO}

A lona degradê azul-cinza tensionada na frente do Paço, cobria sua entrada principal deixando uma pequena passagem lateral pelo jardim para acesso dos visitantes. A estrutura do prédio é também a estrutura formal do trabalho, a moldura do anteparo que se coloca - um raciocínio de preenchimento que fundia este campo de cor no lugar. A arquitetura encontrada já indica a configuração dos trabalhos possíveis, e toda a ação deriva de como o espaço está conformado e seus usos. Mesmo as alterações mais visíveis ou estranhas têm uma relação de continuidade com o lugar. 


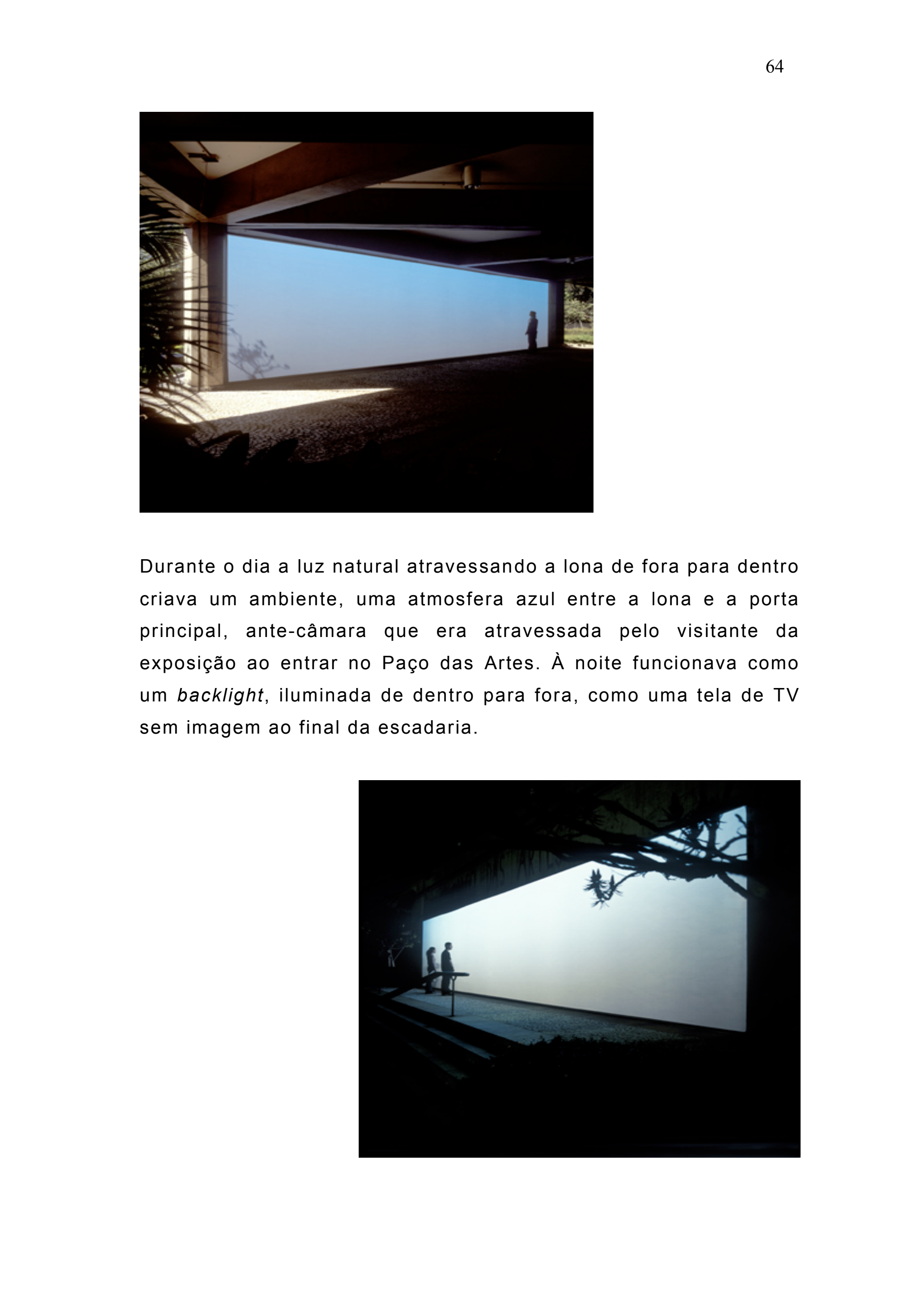




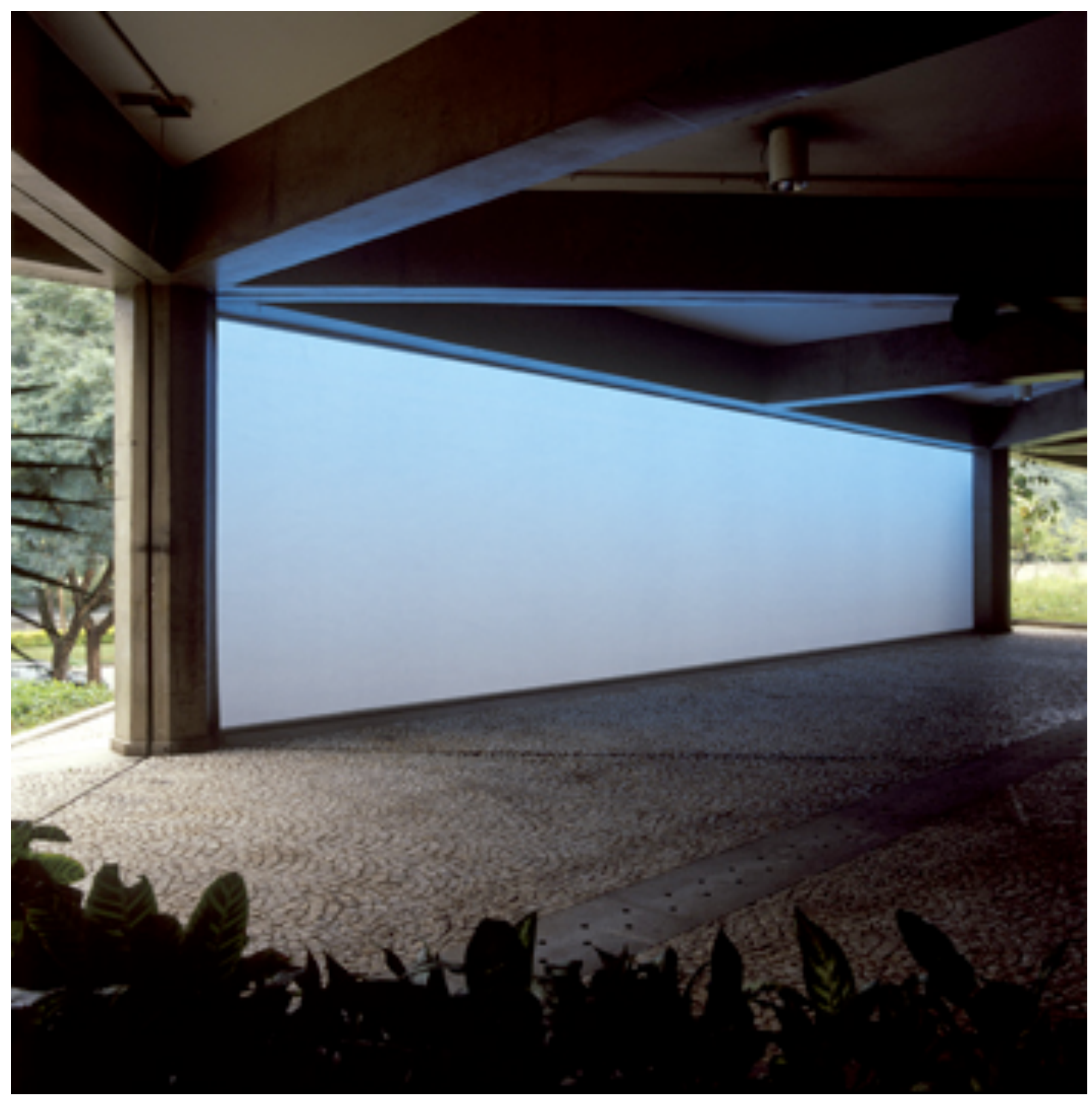

Vi este gradiente luminoso como uma redução da vivência com a paisagem da cidade, gerando uma versão sintética desta experiência. Os primeiros esboços do trabalho foram feitos a partir de imagens fotográficas de céus de São Paulo em dias muitos secos em que o céu sem nuvens começa azul e termina cinza chumbo no horizonte. Ao final as fotografias serviram apenas de referência de matizes e as imagens dos degradês foram construídas artificialmente no computador. 
O gradiente é a síntese de uma série cromática, condensa todas as cores e tonalidades que contém, operando com um princípio de continuidade entre elas. Pode ser percebido como um campo de uma cor única que se altera em direção a suas bordas ou como uma transição entre cores que comporta inúmeras tonalidades intermediárias.

As séries ou diagramas de cor que operavam como novas matrizes para a percepção de um lugar, em trabalhos anteriores como "Gabinete" (II Bienal do Mercosul, Porto Alegre, 1999), "Pátio" (Bienal de Pontevedra, 2000), ou "Clarabóias" (Squatters - Porto 2001) foram substituidas pelos Degradês, condensadas nos gradientes.

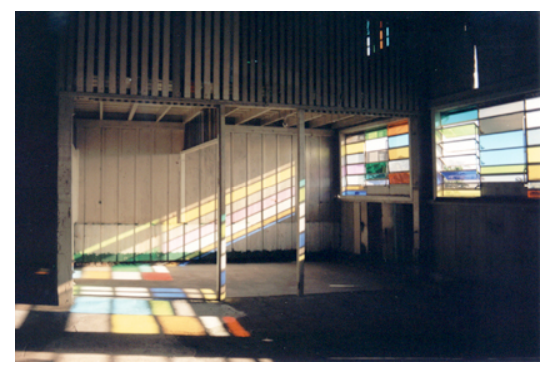

Gabinete,1999. Bienal do Mercosul, Porto Alegre. (acrílico colorido)

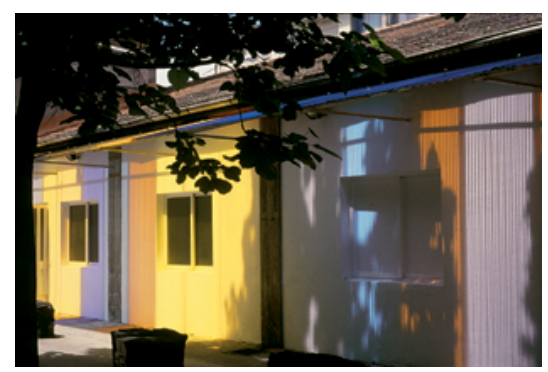

Pátio, 2000. Bienal de Pontevedra, Espanha. (telhas moldadas em acrílico)
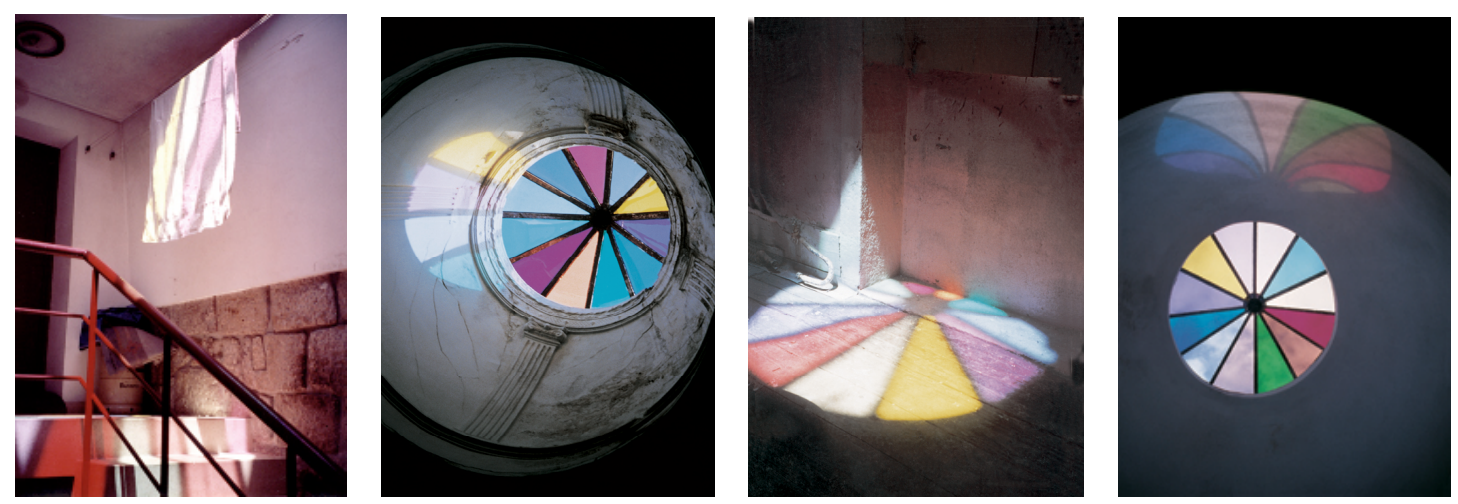

Clarabóias, 2001. Squatters/Ocupações, Porto. (filtros cênicos) 


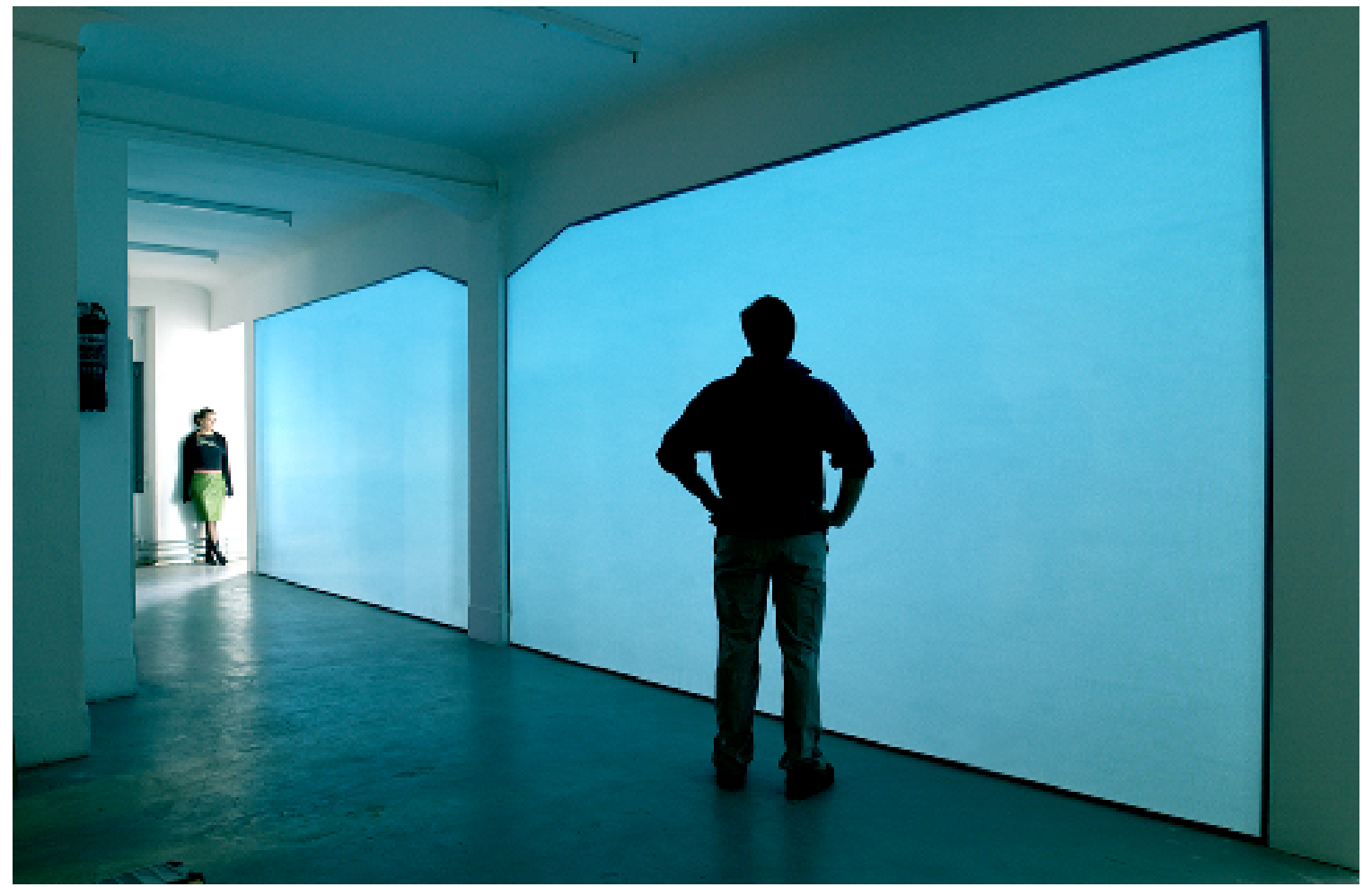

"Degradê SP (adaptado)" - Künstlerhaus Stuttgart , 2004

$\mathrm{Na}$ exposição "Entrepindorama", na Künstlerhaus Stuttgart, o mesmo gradiente foi transportado para outro contexto, outra arquitetura, outra língua. A peça única de lona impressa foi cortada em duas novas partes remontadas lado a lado num exercício importante de deslocamento e reconfiguração de um trabalho para vê-lo operando de outra forma num novo lugar.

Montagem do Degradê SP adaptado ao novo lugar

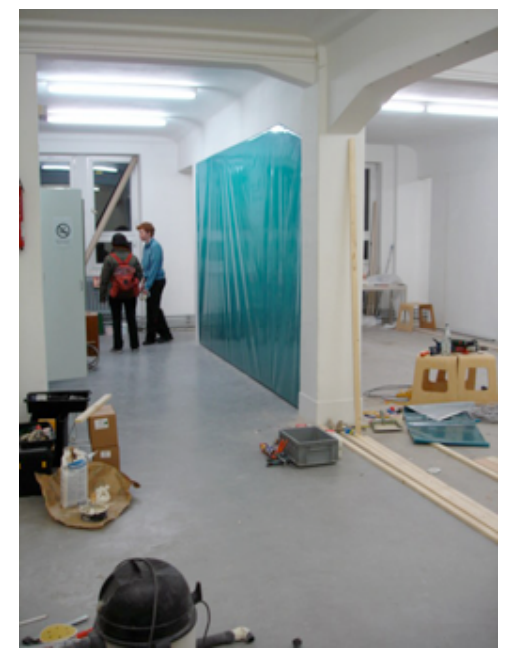



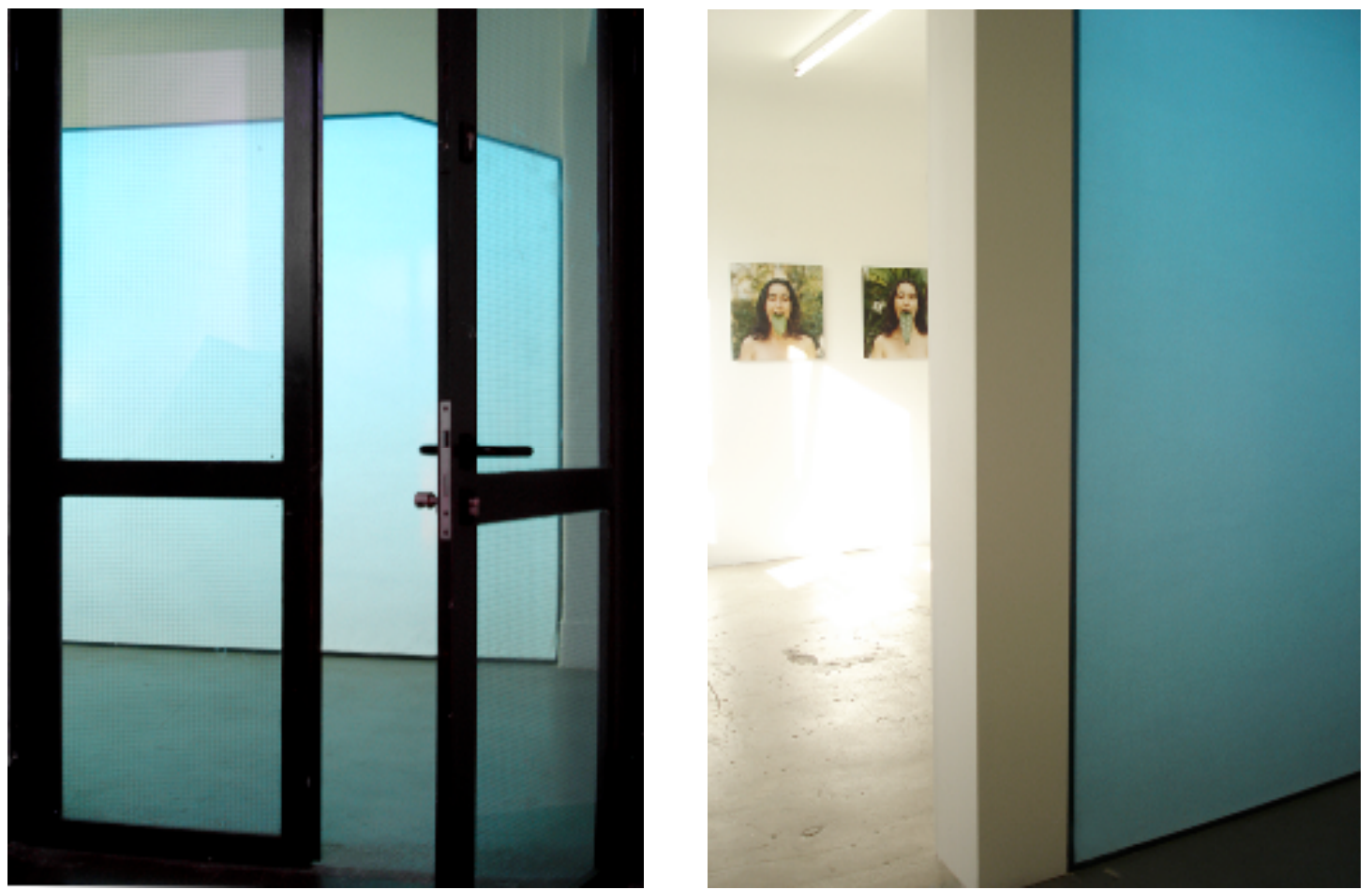

Entrada da sala de exposição, obras de Lia Chaia aparecendo após a parede degradê

A natureza do trabalho com os gradientes não é site-specific, não pertence exclusivamente a um local, instaura ali um outro espaço, assim como havia feito no Paço das Artes. O Degradê SP foi primeiro pensado como anteparo recebendo o espectador, obstáculo luminoso colocado entre o sujeito e o lugar, intervindo na dinâmica do espaço. É preciso desviar-se dele para ver a exposição, contorná-lo, atravessar sua espessura. E a luz que o (retro)ilumina é a luz mesma da exposição, que ilumina também os outros trabalhos exibidos. Na entrada da sala se atravessava, antes mesmo da parede de lona degradê, o seu azul. Sua cor fora dele, formando um campo.

Para tensionar as duas peças degradê, foi usada a estrutura existente, assim como havia sido feito na primeira versão exibida no Paço das Artes. Neste caso acrescentamos duas colunas laterais para delimitar uma área de passagem relativamente estreita e reproduzir a situação anterior em que o visitante era obrigado a desviar desta nova parede para acessar a exposição. 
Com a série de Degradês, feita a partir de 2004, o tipo de transporte experimentado em alguns trabalhos (como em Degradê SP no Paço das Artes e depois na versão exibida em Stuttgart) é intencionalmente uma adequação, uma transformação em sua lógica interna além daquela que o trabalho opera no lugar. Quando a tela translúcida onde está impresso o gradiente de cor é desmontada da estrutura em concreto da entrada, no Paço das Artes em São Paulo, perde limites, forma, configuração e volta a um estado intermediário. Só um outro lugar pode lhe dar novas dimensões e contornos uma vez que não existe enquanto não for tensionada no espaço, não encontrar seus pontos de inserção num lugar concreto.

A remontagem do Degradê SP na Künstlerhaus Stuttgart, significou cortar o material a duas partes e reduzi-lo, tirando dele um pouco do cinza escuro da base, cinza tão identificado com o céu poluído de São Paulo. Os ajustes são feitos não apenas em termos físicos e arquitetônicos, mas são também ajustes de sentido, uma vez que integram novos conjuntos em outro contexto. O que se manteve foi a condição de anteparo translúcido que recebe o espectador antes de tudo, obstáculo que antecede a visita à exposição propriamente dita, que "aparece" apenas quando o contornamos. Criar um campo de cor por ser retroiluminado e filtrar sua própria luz.

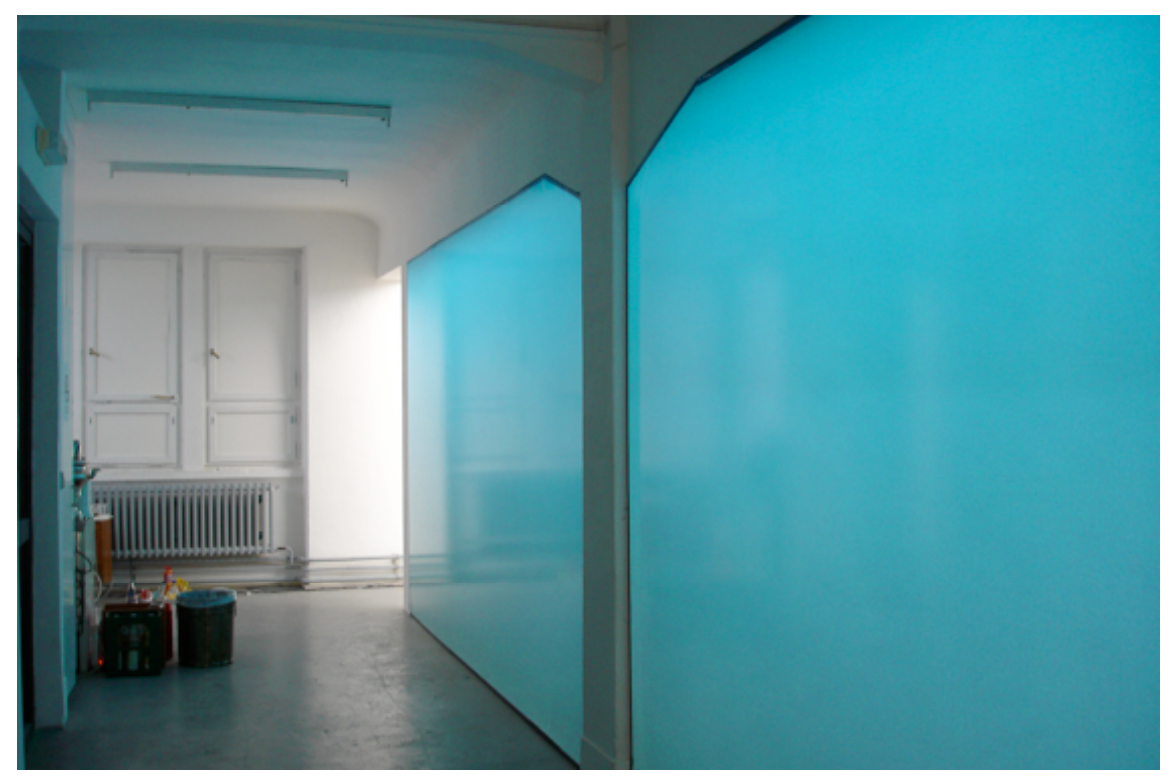



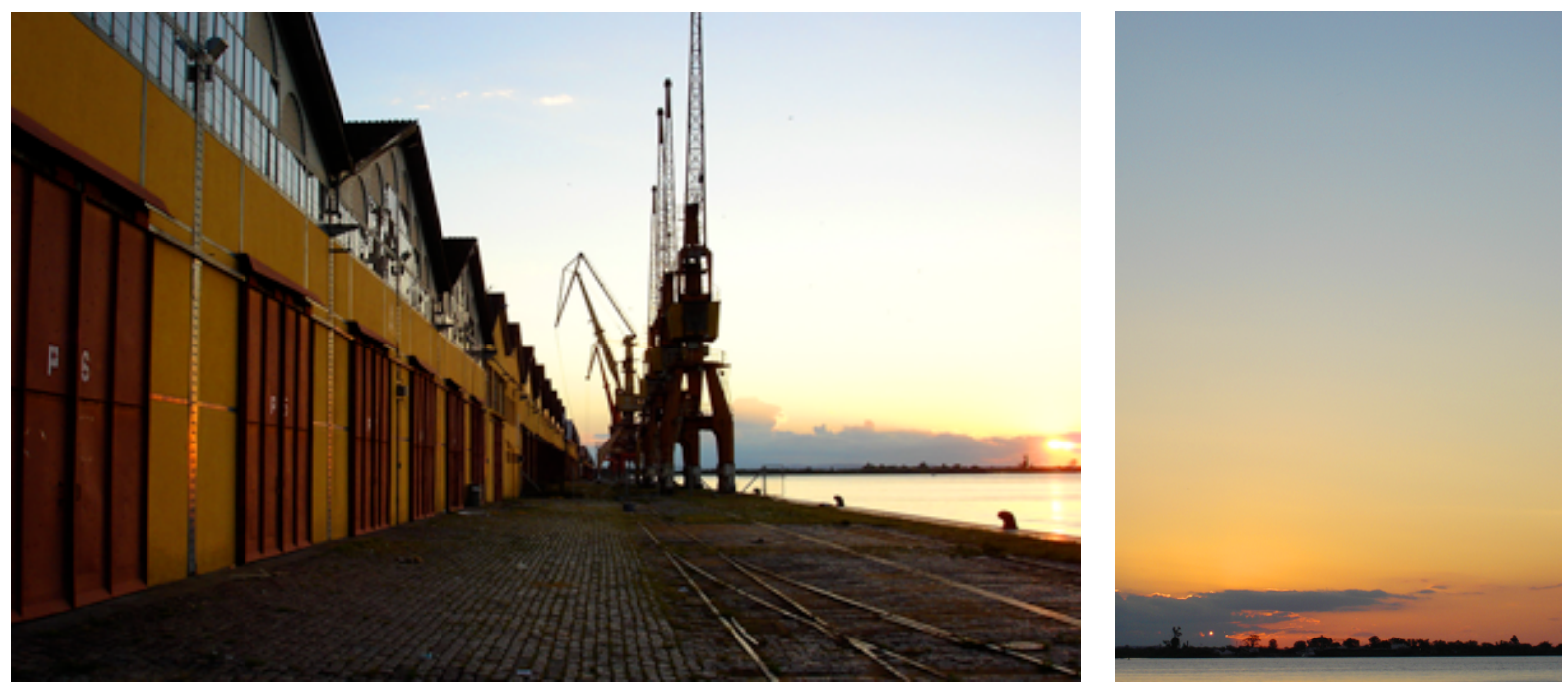

Imagens de pesquisa feitas na preparação do projeto para "Degradês POA", maio de 2005

Uma outra forma de deslocamento experimentada com os degradês foi relacioná-los a uma outra paisagem, refazê-los a partir da experiência com a luz própria de um novo lugar. O projeto para a $5^{\mathrm{a}}$ Bienal do Mercosul em Porto Alegre é também uma adaptação da idéia de síntese da variação cromática do primeiro degradê feito em São Paulo. Para o armazém do cais do porto criei três gradientes a partir de fotografias do anoitecer neste local, como extratos das cores-luz registradas ali e que substituem a visão costumeira do poente no Guaíba.

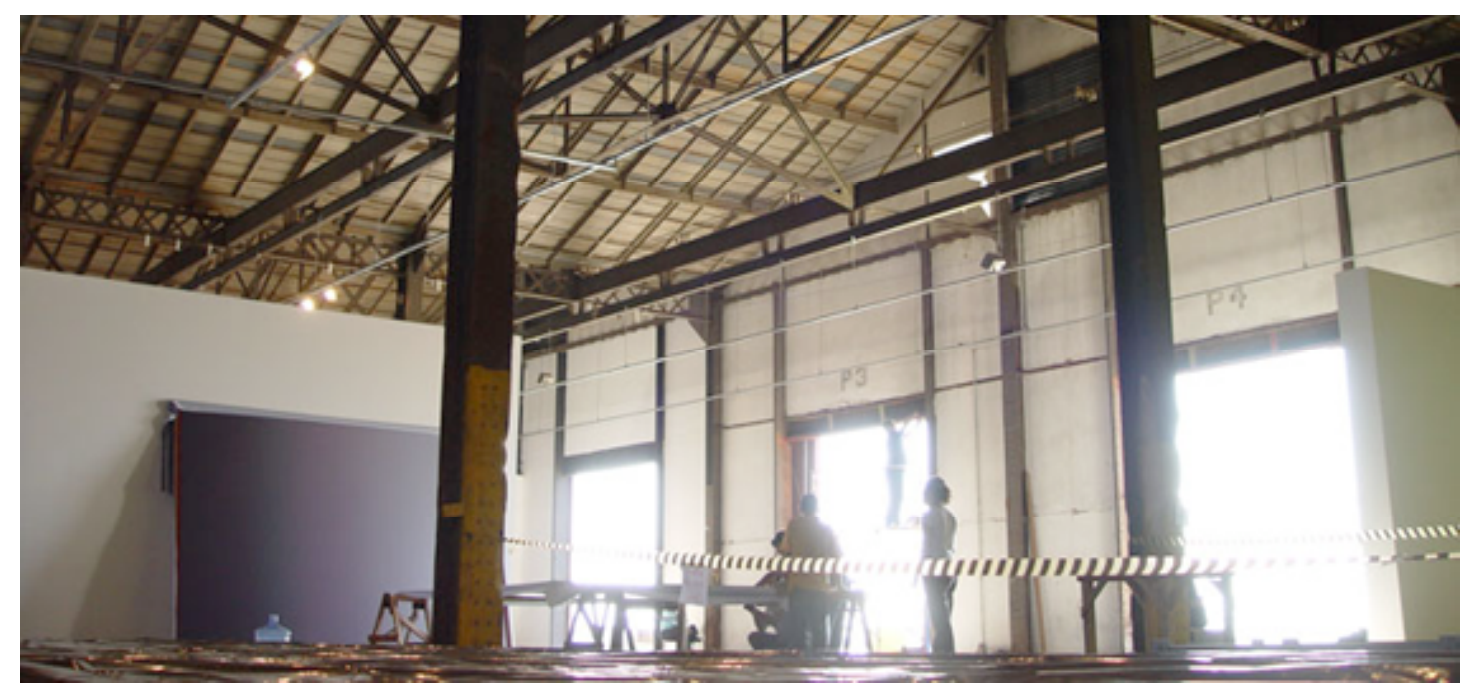

montagem dos painéís de lona vinílica nos portões do armazém, luz natural ainda não filtrada pelos degradês 


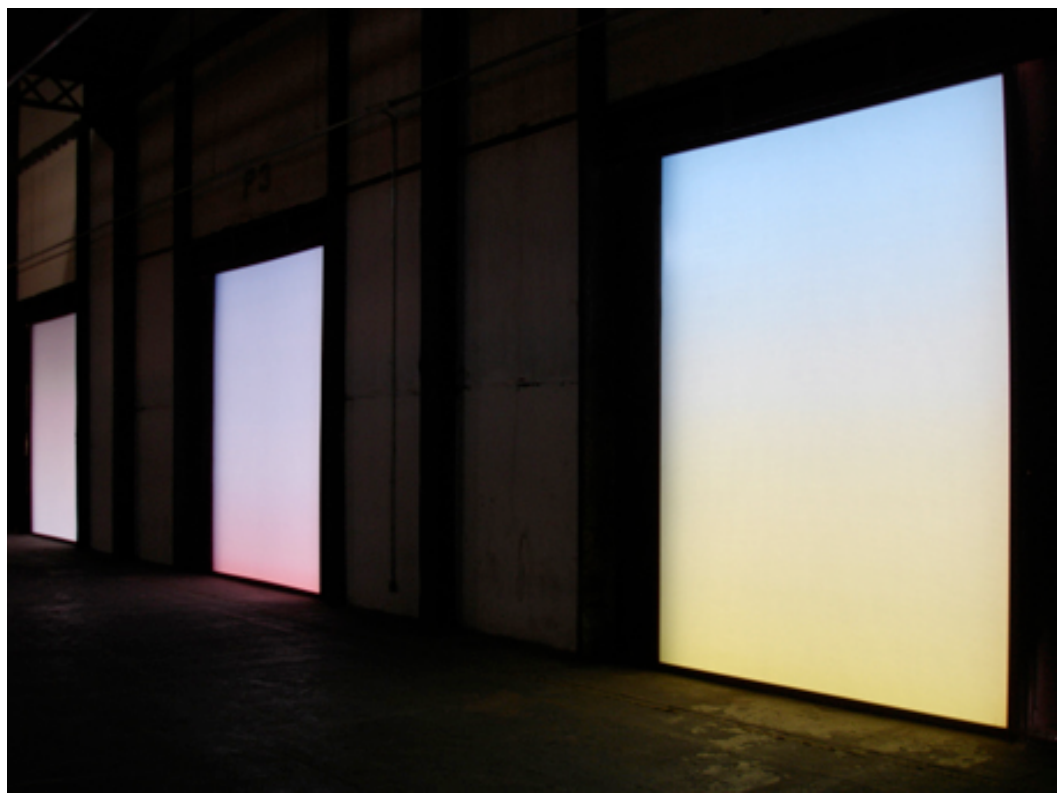

"DegradêsPOA" . 5a Bienal do Mercosul, 2005, Porto Alegre Impressão em lona vinílica translúcida, 3 portões de $440 \times 320 \mathrm{~cm}$ cada

Ao longo do dia a luz do sol mudava de cor alterando a cor de seus filtros e do ambiente iluminado. À noite os degradês eram iluminados de dentro para fora, aparecendo para o observador que via a cidade do rio. Os portões eram também o quadro, a estrutura onde foram tensionadas as lonas. A tensão e a luz que as atravessa produzem o efeito de uma aparente imaterialidade. Embora muitas vezes associados a procedimentos de pintura, estes degradês parecem emitir luz, e se assemelham mais a um monitor de vídeo.

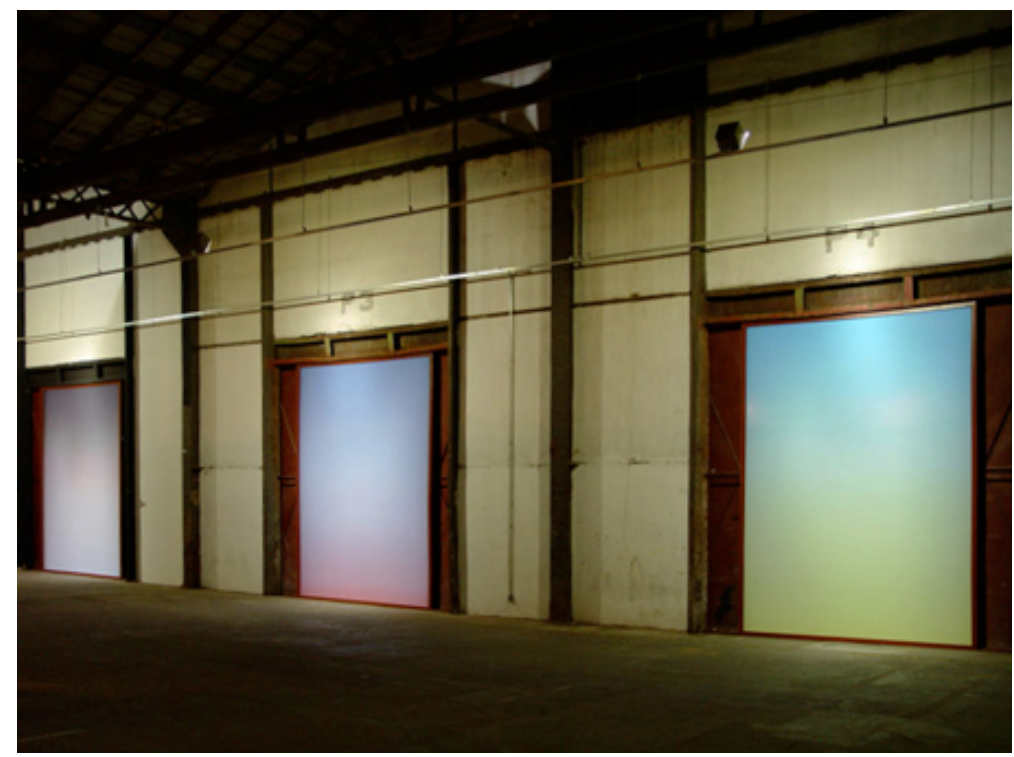


Os galpões que receberam a exposição já não funcionam como depósitos do cais do porto e abrigam hoje eventos que se montam e desmontam, sucessivamente. Com os Degradês POA os portões em desuso são reativados recuperando assim função de abertura: embora preenchidos com as lonas impressas permaneciam abertos a passagem da luz e sensíveis às mudanças externas ao longo do dia. A percepção do tempo se associava a cores e intensidades luminosas.

Quando os visitantes caminhavam do lado de fora do prédio projetavam suas sombras, visíveis de dentro por outros observadores que ao perceberem o efeito trocavam rapidamente de lugar e assim se criava uma comunicação entre sujeitos que não se viam completamente. Também se colocavam como silhueta, fotografando retratos contra fundos degradês. Os gradientes se tornaram, mais do que superfícies de cor, campos ativados para ações espontâneas de vários tipos.
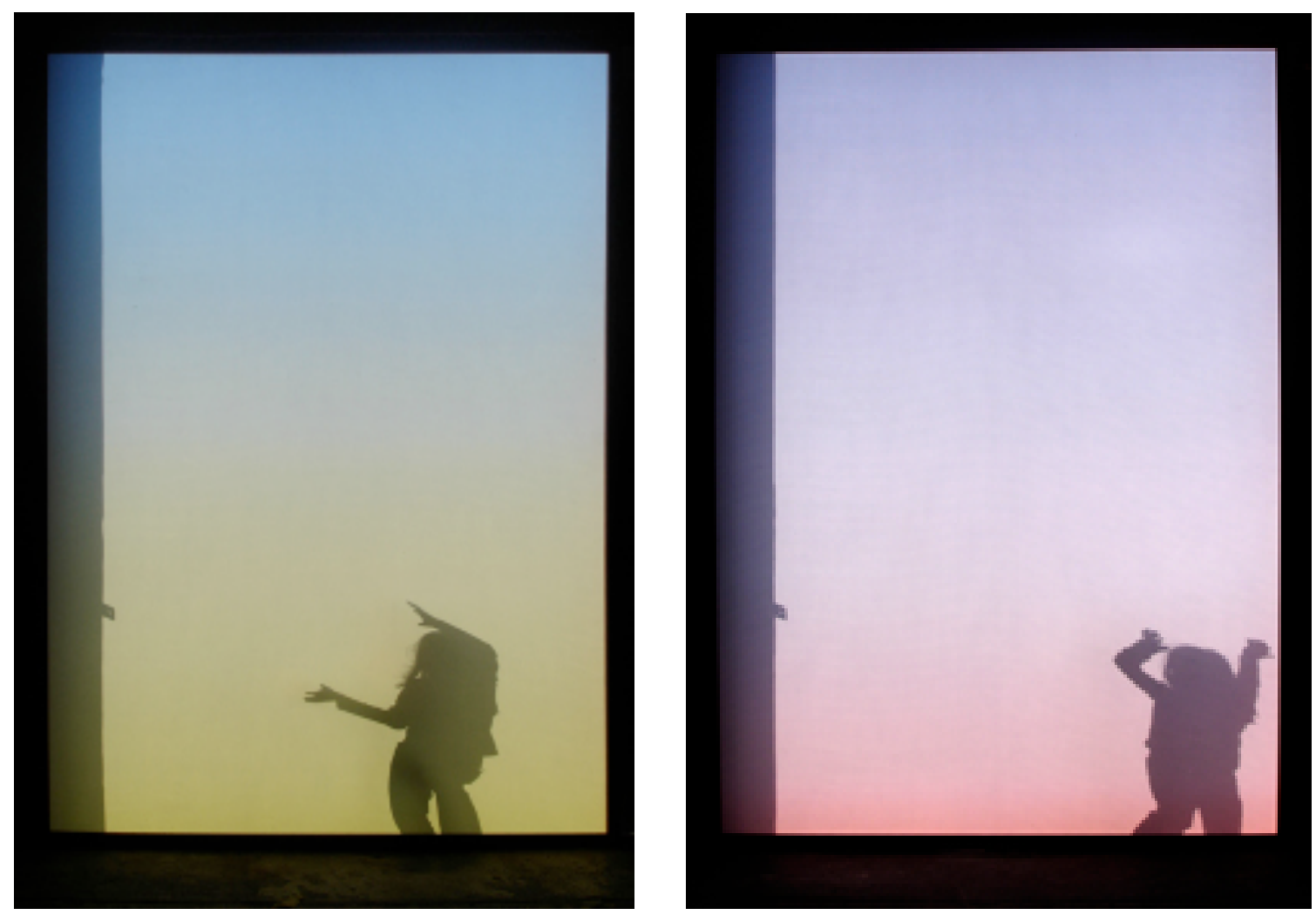

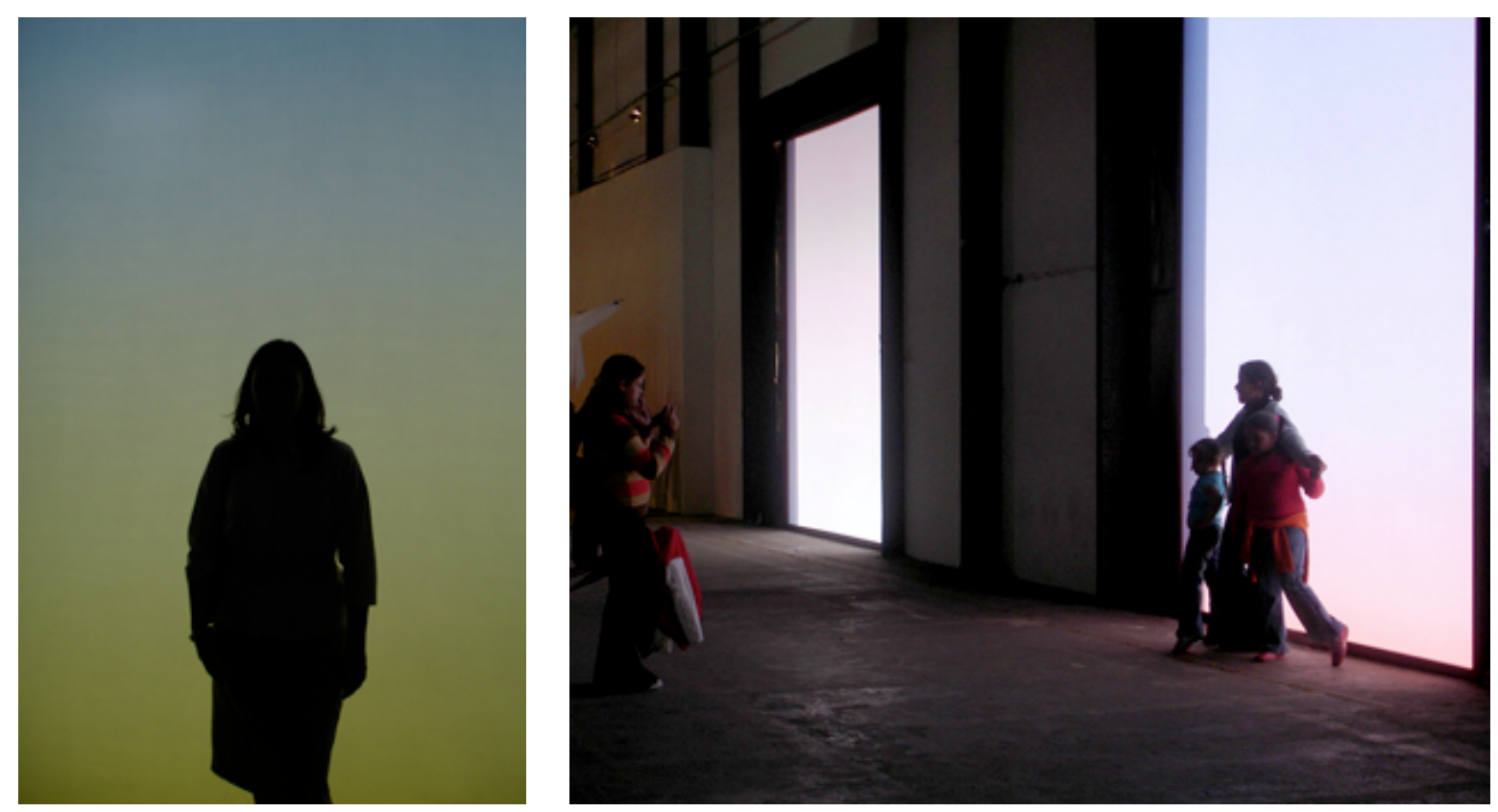

visitantes sendo fotografados por outros visistantes

vista externa dos armazens que abrigavam a Bienal do Mercosul, desde o Lago Guaíba. Podemos ver o verso das lonas vinílicas onde estavam impressos os gradientes de cor, tensionadas em três dos portões abertos.

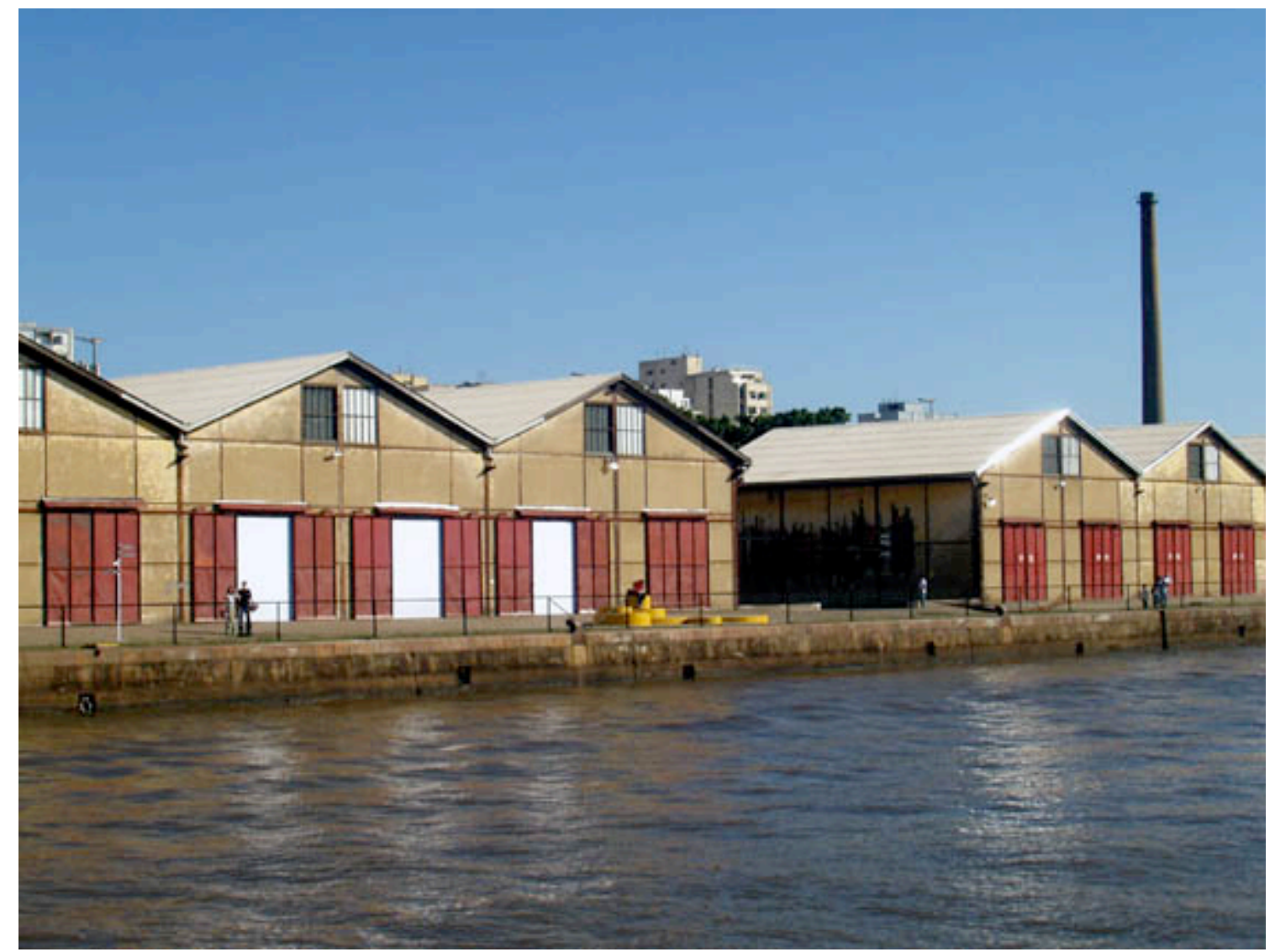


"Não há nada de natural na natureza. Quando a natureza te parecer natural, isso será o fim de tudo e o começo de outra coisa"

Pier Paolo Pasolini

\section{FiLTRO - CINEMA SEM FILME}

A idéia de correção de cor (color correction), vem do termo empregado pela indústria de materiais para efeitos cênicos, referindo-se a alteração na temperatura da cor da luz na iluminação de produções cinematográficas, operada pelo uso de filtros. Se os materiais e equipamentos para efeitos de iluminação usados no cinema consideram o registro da luz construída na película fotossensível, nas camadas de azul, vermelho e verde fundidas no acetato, e através dos processos químicos para revelar esta gravação, quando estes filtros são usados sem película, para a experiência a olho nu, os efeitos são mais imprecisos e imprevisíveis, demandando um fazer experimental. Como não se imprimem em substrato estável, mas apenas nos sujeitos, os efeitos são cambiantes, se transformam com as variações nas condições de iluminação do local, tanto operando em fontes de luz natural como artificiais.

Os trabalhos que chamo Correções de Luz / Light Corrections são feitos com estes filtros para cinema. Os filtros são usados para a "correção" das condições de iluminação existentes, difusores ou filtros de cor que recriam no lugar uma luz ambiente outra, de alguma forma reconhecível, mas deslocada. A evidência de um dispositivo acende a idéia do artifício, do não-natural. Mas a distinção atribuída entre natural e construído, é menos consistente no caso de filtros que recriam atmosferas possíveis, verossímeis, um efeito que não identificamos com seu dispositivo. Os filtros para cinema são calibrados para a sensibilidade da luz e cor da pelicula e seu processamento químico, mas operam de outra forma quando 
expostos ao vivo. Na tela de cinema aceitamos toda a luz como natural, capturada na "realidade" onde a ficção é encenada. Quando reencontramos estes efeitos no espaço que frequentamos temos a chance de experimentar um lugar ficcional onde a realidade continua acontecendo.
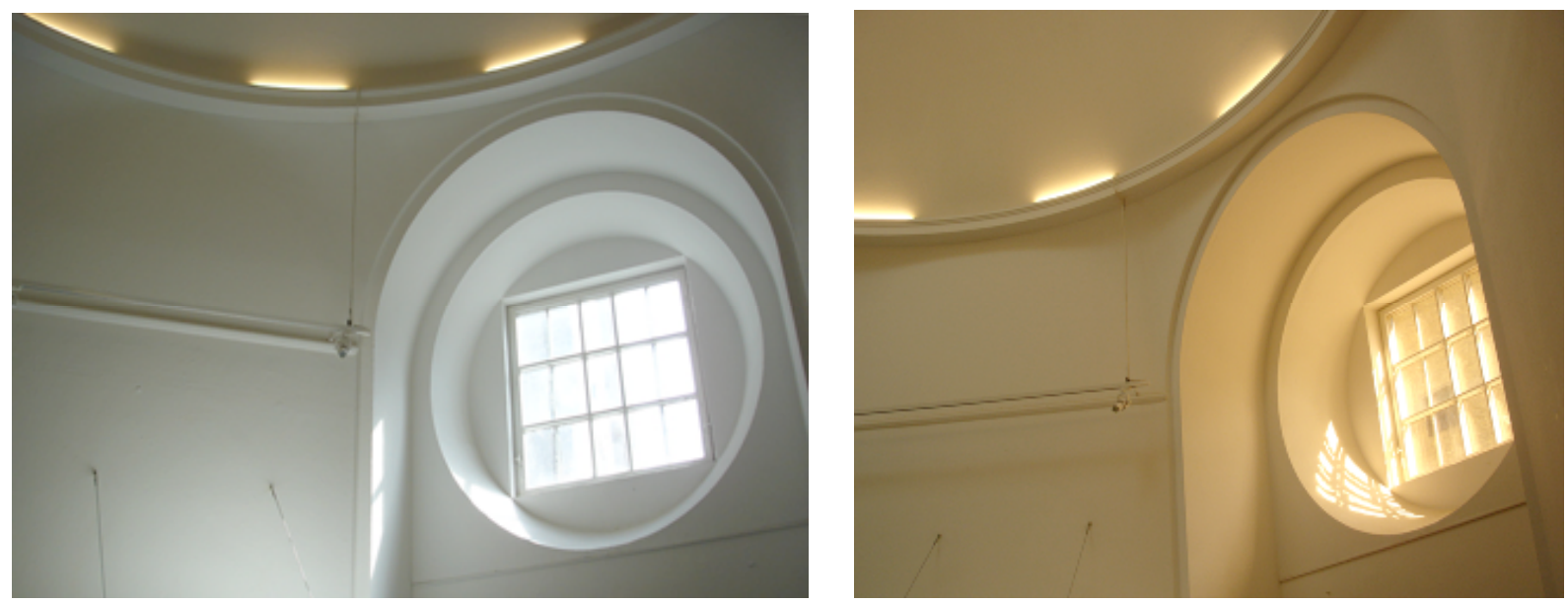

Light Corrections $-3^{\text {a }}$ Bienal de Göteborg, 2005 oktagon (antes e depois)

O conceito da Bienal de Göteborg estava exposto em seu título "More than this! Negotiating realities", e também na maneira como a mostra se constituiu. Os 12 artistas foram convidados a um encontro em Göteborg para conhecerem os espaços e a cidade, e principalmente para trocarem imagens de seus trabalhos, falando de seus projetos recentes e de suas idéias para o lugar. Com isso se criou uma espécie de espaço de negociação, embora cada um estivesse exclusivamente concentrado na concepção de seu próprio trabalho. E este foi o espaço que meu projeto procurou manter ativado propondo alterações nas condições de iluminação de todos os ambientes que faziam parte da experiência dos visitantes da exposição. Ao mesmo tempo que incluía assim áreas que habitualmente não são usadas para exibição como corredores, cafés, chapelaria, também afetava a luz nas salas ocupadas por cada artista. Ao contrário do que normalmente se procura criar no conjunto de uma exposição coletiva - as tais condições ideais de temperatura e pressão sempre tão improváveis que garantiriam uma 
espécie de isolamento das obras em relação ao contexto, não deixando vazar som ou luz de um espaço para outro - as Light Corrections projetavam ali diferenças ambientais e interferências entre obras. Aquilo que se deveria evitar na busca da maior neutralidade possível para a apreciação de cada obra era justamente o que eu desejava e propunha fazer operar intencionalmente: a passagem entre um trabalho e outro sem descompressão e perturbada por uma mudança atmosférica sensível.

O projeto foi não apenas resposta a um contexto mas à linguagem arquitetônica do lugar da exposicão, tirando partido de suas singularidades. A arquitetura da Konsthalle e do KonstMuseum, locações da Bienal, oferece muitas janelas e paredes de vidro, mas principalmente clarabóias, que são iluminadas tanto por luz natural quanto artificial, pois na renovação dos prédios um novo telhado foi construdo sobre o original e com isso há na verdade duas clarabóias sobrebostas. Eu instalei os filtros no espaço entre elas, onde há também refletores para a iluminação das exposições que usam o vidro jateado das clarabóias como um grande difusor.
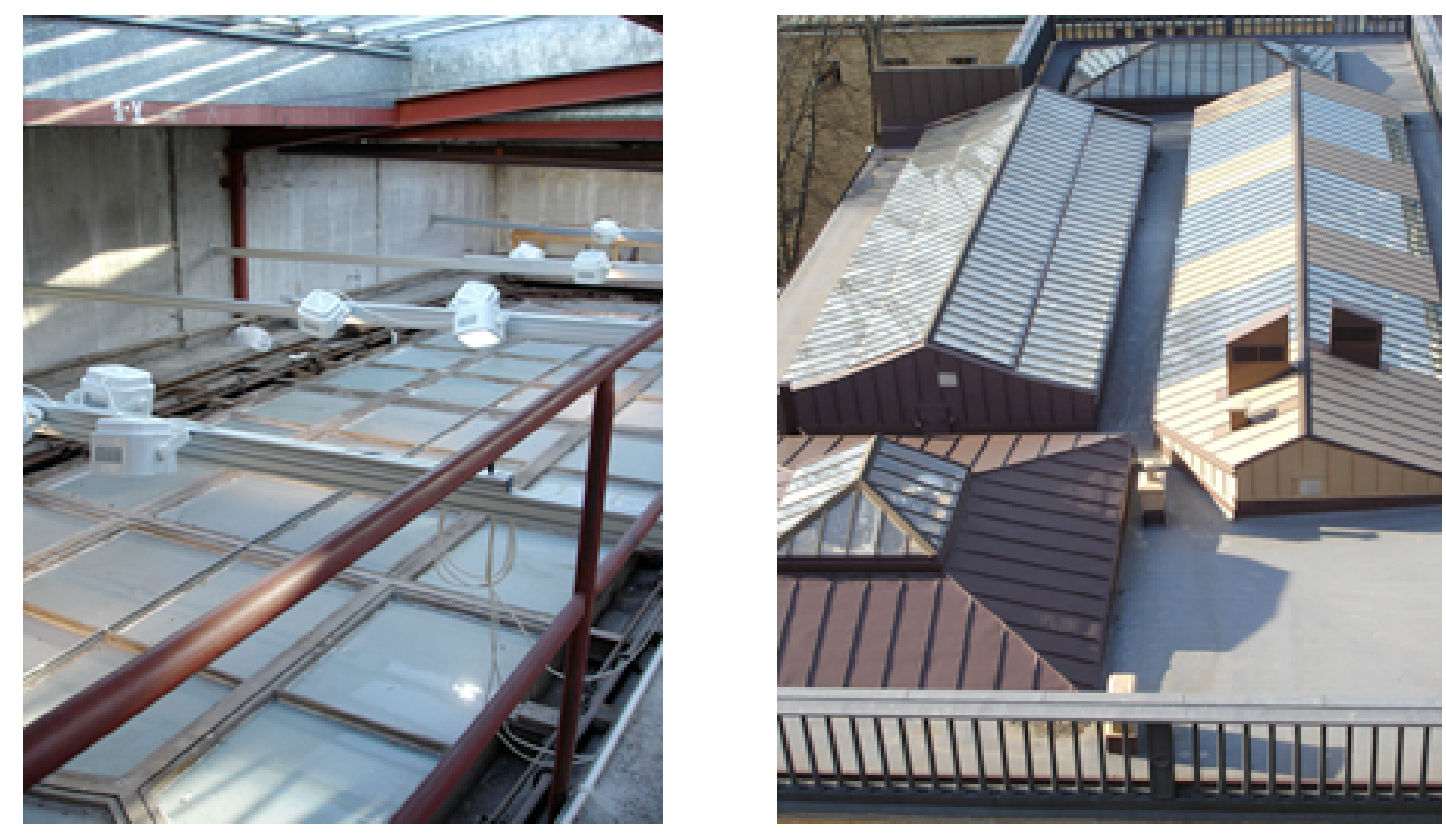

Clarabóias da Konsthalle, vistas interna e externa 
Propor interferir no espaço de cada uma das obras só foi possível porque havia esta disposição da curadoria em intermediar as negociações com os outros artistas, em primeiro lugar aceitando e dando suporte ao projeto e em segundo fazendo um contato introdutório com todos eles mostrando o interesse na sua realização. A partir daí nos comunicamos por e-mail, conversando sobre cada projeto e os espaços escolhidos, como eles pensavam configurar seus trabalhos, conceito, atmosfera, temperatura e quantidade de luz. Em alguns casos como o de Gerard Byrne e Runa Islam, as projeções de seus filmes exigiam uma sala completamente escura, e optamos por não intervir ali. Mas o trabalho de Miriam Backström, também uma projeção de vídeo foi montado de forma a receber alguma luz, pois a tela ficava instalada dentro de uma tenda. Sua sala era imensa e tinha uma claraboia que ocupava quase todo o teto, inundando o espaço de luz durante o dia. O que fiz foi então usar sob a claraboia um filtro de densidade neutra cinza que não alterava a temperatura de cor da luz mas reduzia em $80 \%$ a luminosidade criando um dia escuro, uma atmosfera de tempestade. Houve uma certa tensão neste caso pois, embora a presença do filtro não se impusesse, seu efeito era sutilmente presente e aparecia na fala dos visitantes como uma impressão importante. Miriam sugeriu que reduzissemos mais a luz, eliminando este efeito, mas em conversas com os curadores decidimos mantê-lo.
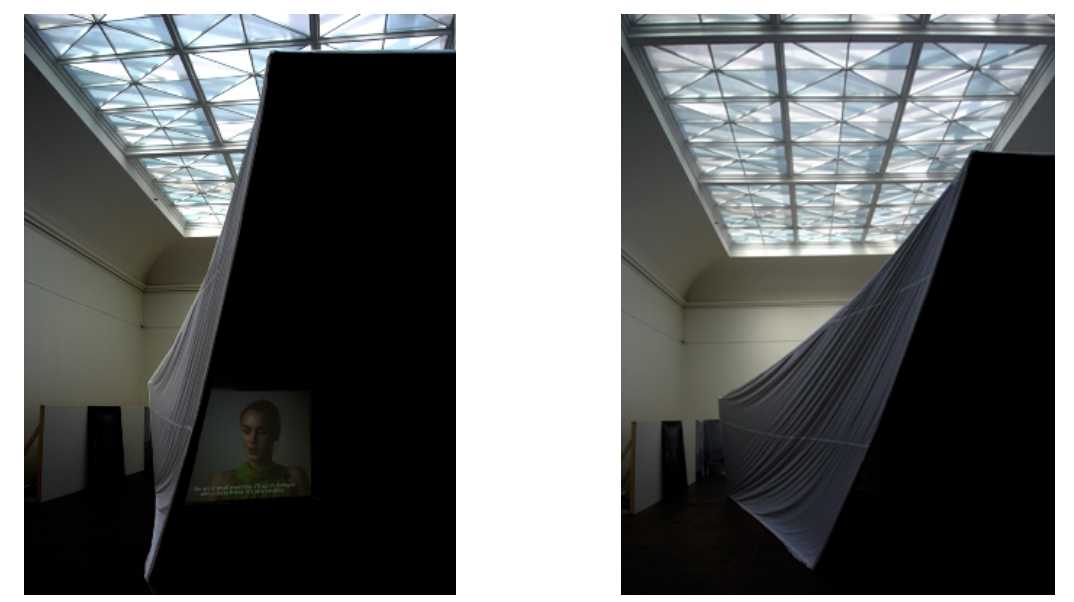

Filtro ND.9 (densidade neutra) na claraboia da sala onde Miriam Bäckström expôs "Rebecka". 
Na sala ao lado de Miriam, Adrian Paci exibia sua "Pasolini Chapel", uma cabana construída com pedaços de madeira encontrados e povoada por pequenas pinturas P\&B de stills do Evangelho segundo São Mateus. Paci foi o único que especificou a luz desejada: warm (quente). Minha pesquisa começou revendo filmes de Pier Paolo Pasolini(1922/1975) até encontrar a cor de luz para sua sala. Em Medéia (1970), Pasolini representa os espaços fechados e abertos com a mesma luz âmbar, talvez querendo indicar que o mundo construido ainda era ali primitivo demais, muito semelhante ao mundo natural, contínuo em relação a ele. Um pouco como a idéia que eu fazia desta cabana primitiva construída por Adrian, então pensei que faria sentido uma luz contínua entre seus exterior e interior. A luz que iluminaria as pinturas dentro da cabana era a de uma lâmpada incadescente comum, então buscava uma temperatura de cor entre aquele âmbar dourado de Pasolini e a luz desta lâmpada. Natureza e artifício confundidos me pareciam potentes para responder a proposição de realidades negociadas.
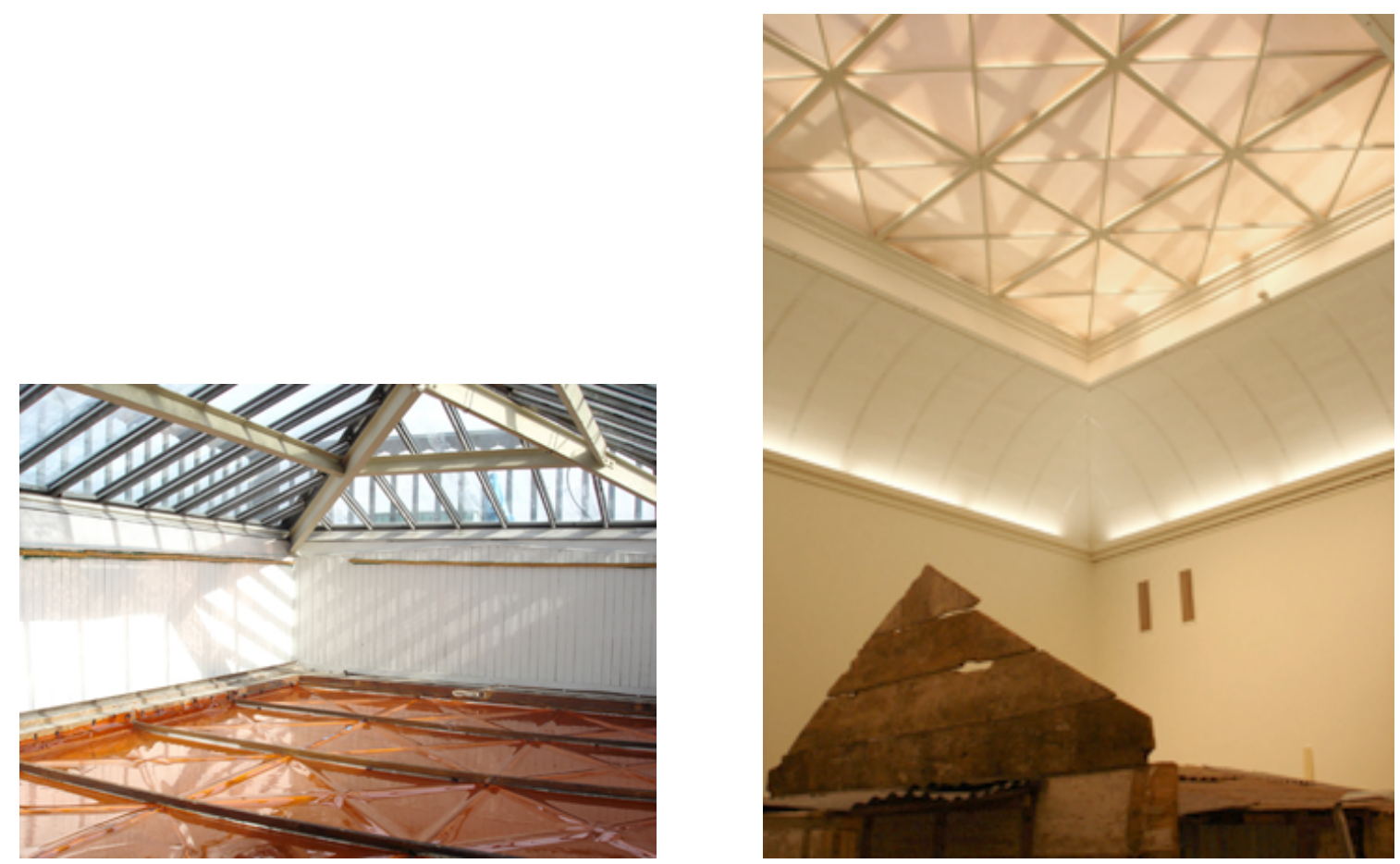

Filtro apricot sobre clarabóia da sala onde foi exibida a obra de Adrian Paci, "Pasolini Chapel". 
Quando consultei fotógrafos de cinema, perguntando sobre como recriar a luz do filme Medéia, descobri que aquela cor era obtida não na filmagem mas no processamento químico da película gravada, e passei a experimentar vários filtros até encontrar a medida da cor que queria refazer ao vivo no espaço. Construí maquetes das salas nas quais trabalhei para observar o efeito dos filtros com a luz natural iluminando o espaço branco.

Na passagem da sala de Paci para a do trabalho de Bäckström. E vice-versa havia um lapso de tempo para o ajuste do olhar até aceitar a luz no ambiente como quase natural, mas olhando de uma sala para outra as atmosfera apareciam como campos de cor, pelo contraste de temperatura da luz entre elas.
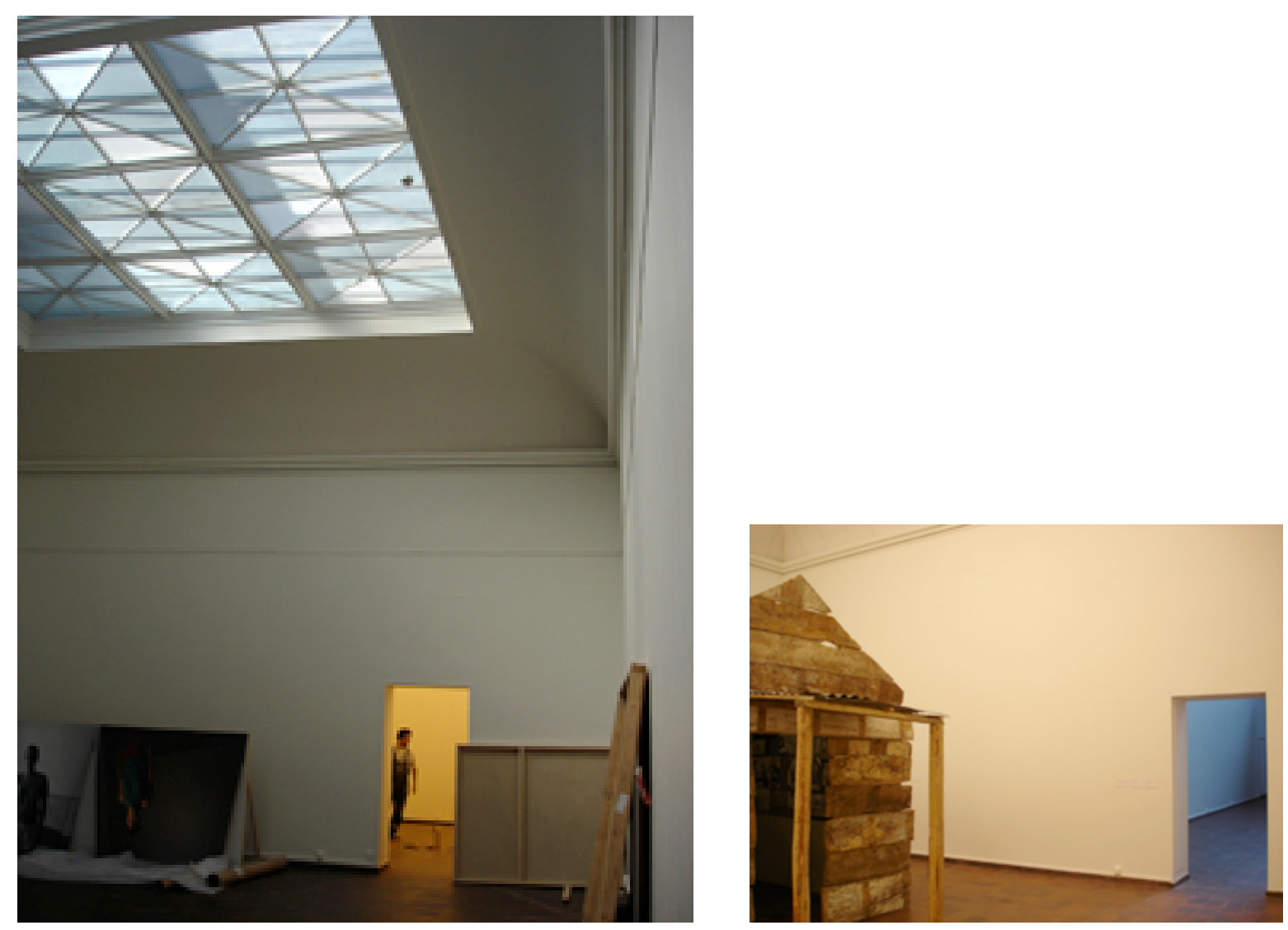

Sala de Miriam Backström com porta para sala de Adrian Paci e sala de Adrian Paci com porta para sala de Miriam Backström: efeitos na iluminação são percebidos como cor pelo contraste. 
Em nossa primeira visita, a entrada do museu me pareceu muito escura apesar da fachada de vidro, como indicando um lugar fechado onde nada acontecia. Como no primeiro projeto geral da exposição não haveria ali obra de outro artista, pensei em um filtro amarelo luminoso e vibrante cobrindo a fachada de vidro para "acender" a entrada, fazendo o visitante atravessar uma massa de luz amarela ao entrar na exposição.

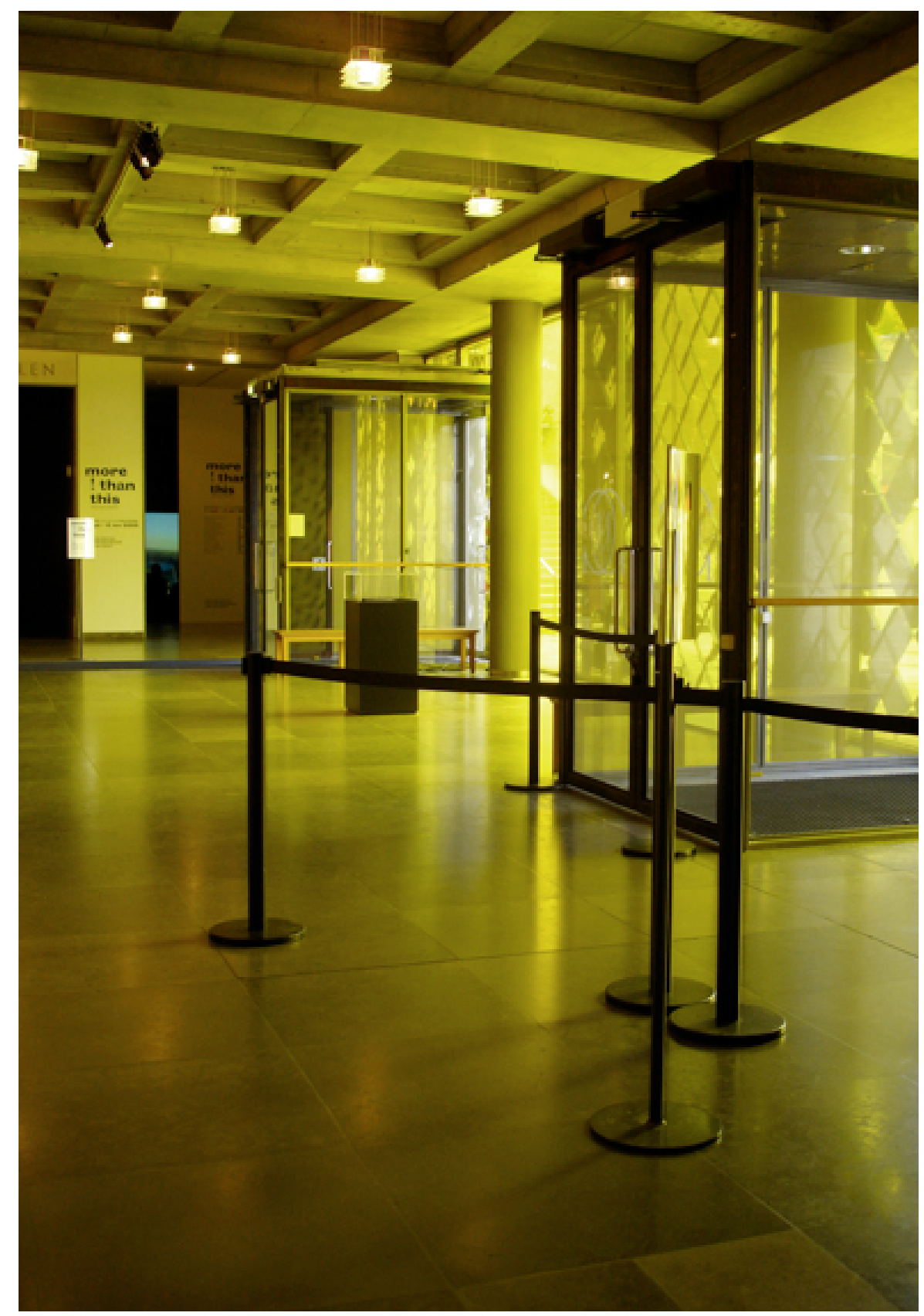

Filtro yellow N.10 nos vidros da entrada do Konstmuseum 
No período da montagem soube que haviam incluído uma peça de Christian Andersson no espaço entre as portas de entrada, junto ao vidro. Conversando com Christian, decidimos manter o filtro pois ele criava uma certa vibração que de certa forma reafirmava a idéia de seu trabalho: "The Philadelfia Experiment" era a capa de uma fita VHS, surrada cópia de um filme de terror americano dos anos 50 , exposta em uma base preta e coberto por uma redoma de acrílico. Havia um dispositivo oculto que ligava o objeto a um motor vibrando em altíssima frequência ao ponto de não vermos o movimento mas um efeito de perda de foco. Um objeto fora de foco de tanto vibrar. Neste caso a confluência natural dos projetos apareceu inesperadamente. Também Michael Beutler localizou seu trabalho próximo a esta parede transparente e amarela, mas do lado de fora, e era através dela que víamos as estruturas de tendas numa desordem construída na praça em frente ao museu. O filtro era o elemento que fundia, ao invés de separar, as duas obras vizinhas localizadas dentro e fora.

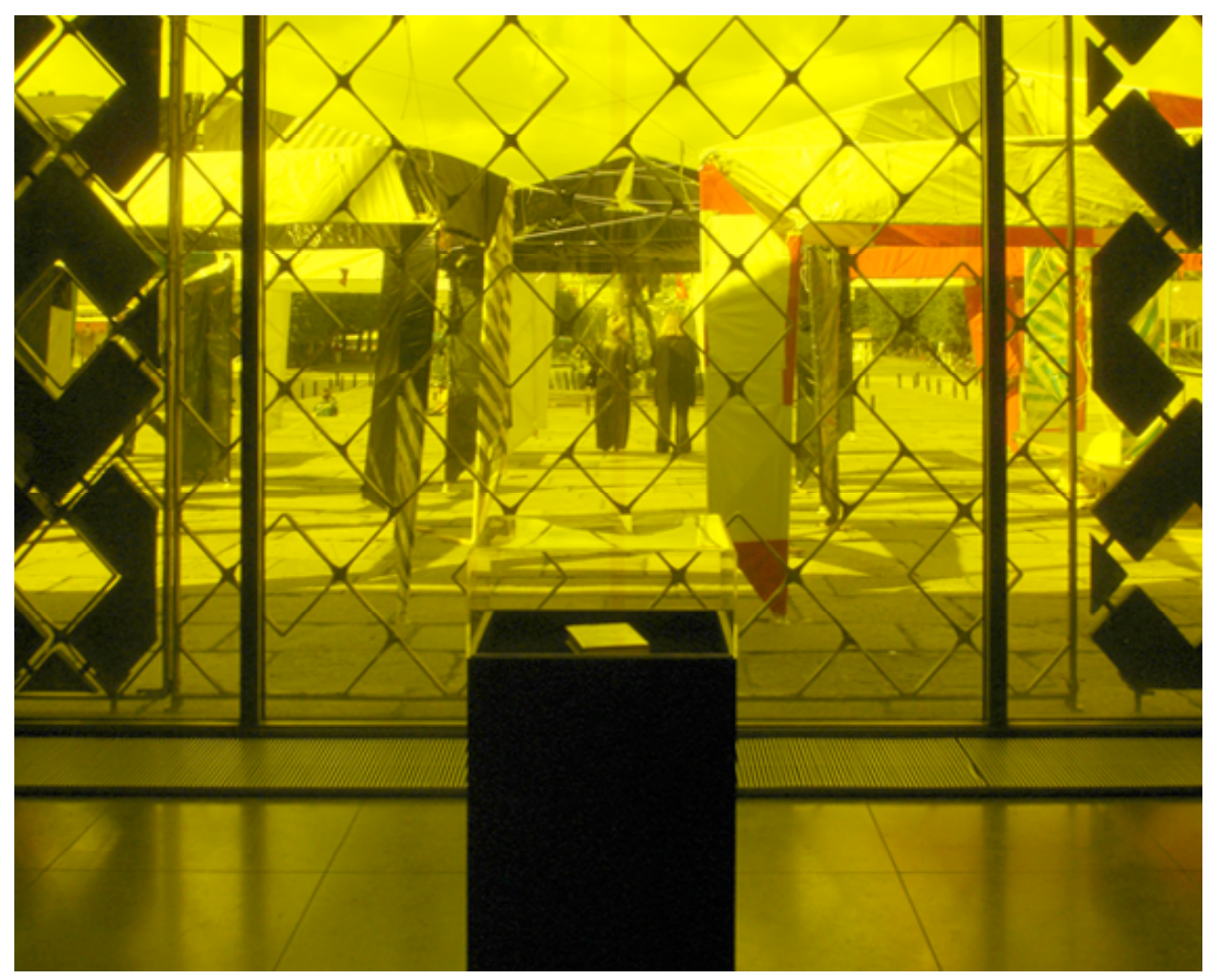

Obras de Christian Andersson (dentro) e Michael Beutler (fora) 
A sala maior do museu, que continha os espaços - abertos ou fechados - de vários trabalhos (Marcel Odenbach, Monica Bonvicini, Ann Lislegaard, Christian Andersson), tinha uma face de vidro, em toda sua extensão (30 mts). Ali instalei uma sequência de filtros de correção de temperatura de cor , "corrigindo" natural para artificial e vice-versa, assim como os chamados ND-densidade neutra que só alteravam a quantidade de luz. Eram cinzas e âmbares em faixas de $150 \mathrm{~cm}$ de largura suspensas e cobrindo toda a área transparente, sobrepondo-se a cada emenda e criando assim, novos filtros mistos. A sequência de faixas verticais era percorrida não apenas pelos visitantes da exposição que viam o jardim lá fora ora ensolarado ora sombrio, luz de fim do dia, sol da manhã, sucessivamente, mas também pelos que atravessavam o jardim e entravam e saiam destes campos, na visão de quem observava de dentro. A luz no interior da sala não tinha sua cor muito alterada pois os matizes dos filtros de correção eram complementares e como mistura de cor-luz é aditiva, quanto mais diferentes as cores-luz somadas, mais próxima do branco é a luz resultante.

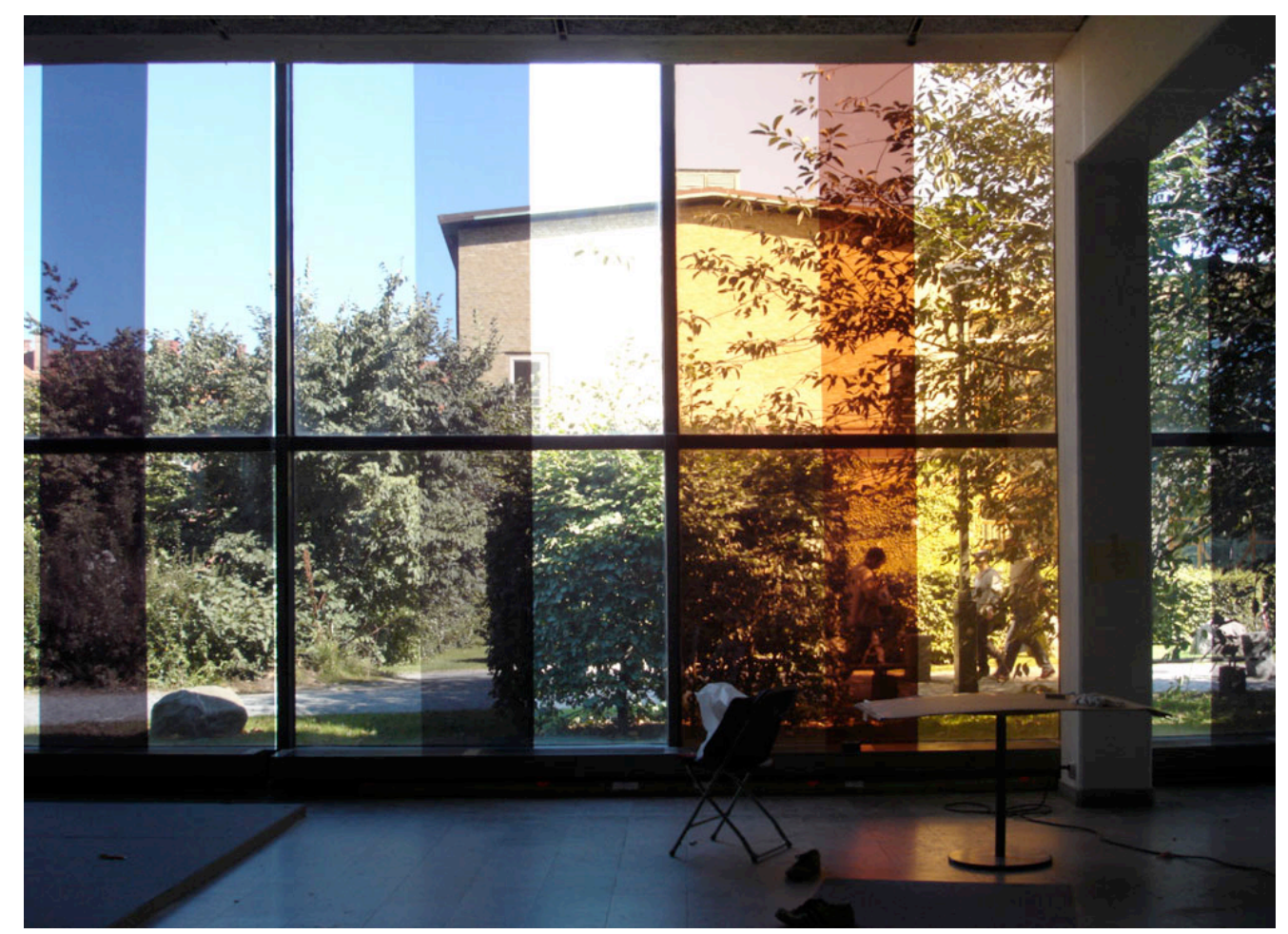

Sequência de filtros de correção de cor para cinema (densidade neutra e $5500^{\circ} \mathrm{K}>3200^{\circ} \mathrm{K}$ ). 
No hall de entrada da Konsthalle, chamado de Oktagon por sua forma octogonal, haviam janela, clarabóia e um círculo de lâmpadas fluorescentes. Filtrei a luz da janela, "corrigindo-a" para uma temperatura mais baixa (de $5500^{\circ} \mathrm{K}$ para $3200^{\circ} \mathrm{k}$, natural para artificial). Embora a luz resultante fosse de cor semelhante a do círculo de lâmpadas que dividia janela e clarabóia o efeito era de uma luz natural um pouco mais quente. Esta luz "nova" era tão verossímil que só se podia percebê-la como artificial quando se permanecia tempo suficiente ou voltando a este ambiente, pois se tinha a impressão de um longo entardecer que não acabava enquanto houvesse luz do sol. Também a diferença entre a cor da luz entrando pela clarabóia não filtrada indicava a presença de um filtro, embora pusesse a questão de em qual abertura havia uma interferência, enfim, qual luz era mais real, natural ou verdadeira. Questão imprópria para pensar aquela luz, que era um fato concreto ali.

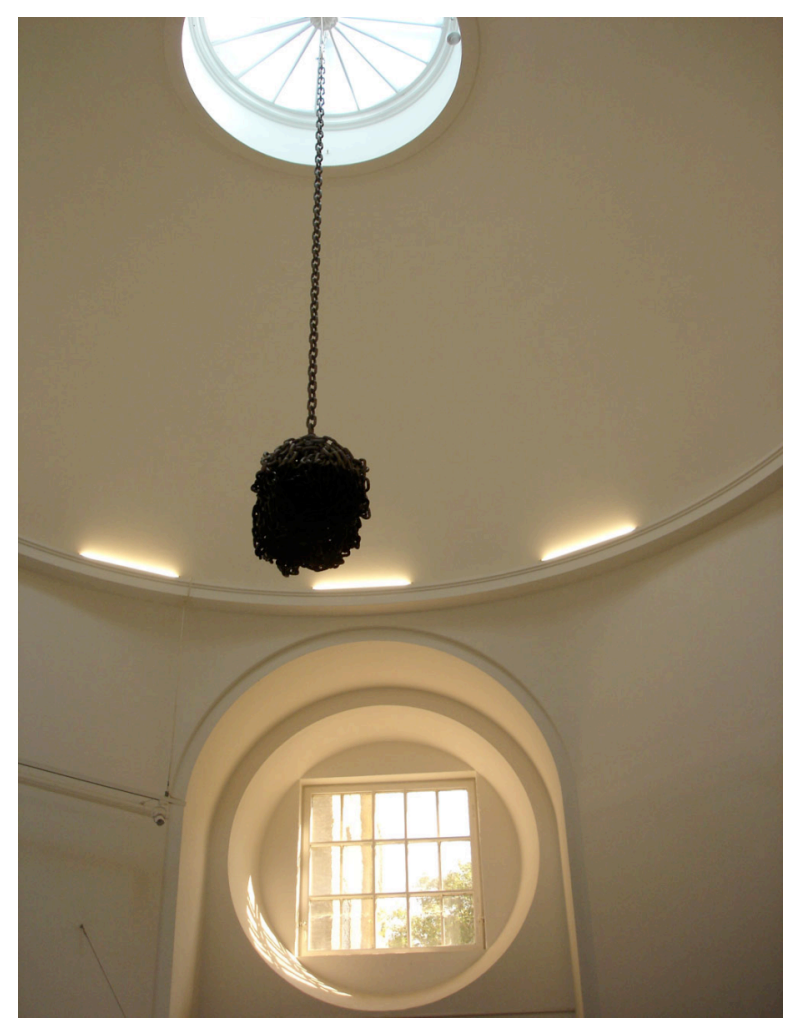

Filtro \#85 na janela do hall de entrada, ao centro trabalho de Monica Bonvicini. 
Num trabalho de iluminação convencional se precisaria investigar qual seria a luz ideal, "boa" ou "má" para determinado assunto. No caso destas "light corrections" o conceito de luz correta foi substituído pela idéia de uma luz própria de cada trabalho, que acendesse algum aspecto seu escolhido por mim. Luz nada neutra, atribuída por um modo de ver e discutida, observada, ajustada com os artistas e curadores.

Durante a montagem da exposição houve um convívio que não era apenas "social", mas movido pelas trocas de opinião entre os artistas a respeito de seus projetos e suas instalações, que foram se tornando mais produtivas a medida que a montagem ou construção dos trabalhos avançava. Acredito que de certa forma a necessidade de negociar os limites entre as obras $e$ as interferências que propus desencadearam esta prática, que é incomum em exposições internacionais, onde os artistas normalmente não se conhecem e raramente comentam algo um sobre o projeto do outro. Também o primeiro contato promovido pela curadoria teve o efeito de fazer-nos pensar sobre os projetos de cada um em relação ao conjunto.

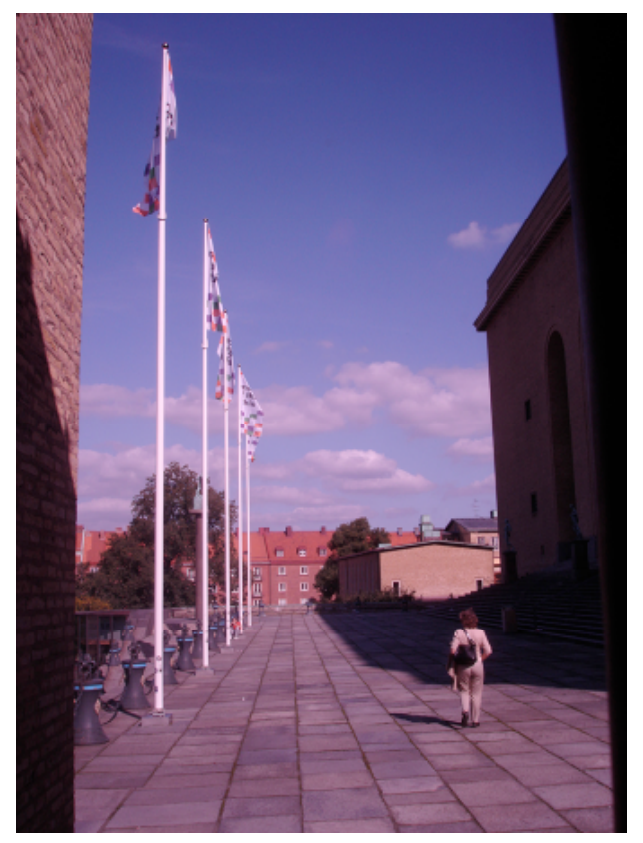


Filtro plum \#112, janela do kafe

As Correções de Luz em várias salas do Centro Universitário Mariantonia foram essencialmente diferentes das realizadas em Göteborg para a exposição More than this!. No Mariantonia havia um projeto individual ocupando sozinho alguns espaços do prédio as áreas de circulação e a sala de exposição mantida vazia de objetos. Não eram compartilhados com outros artistas. A única negociação necessária era com a instituição, sobre acessos, funcionamento, montagem.

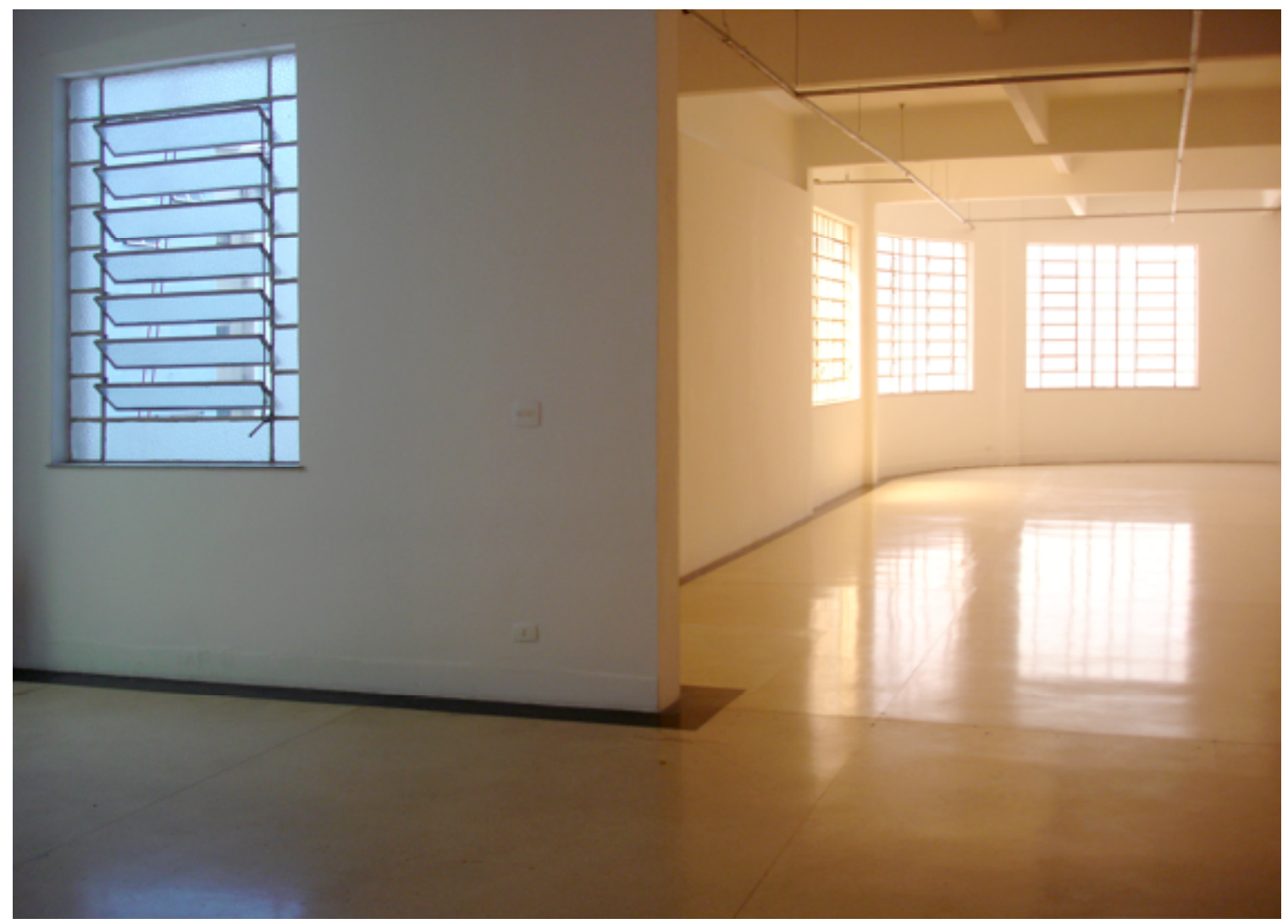

Em cada uma das janelas foi fixado, externamente um filtro de correção de cor, e como elas nunca eram completamente abertas o vidro texturizado acabava por esconder o filtro de policarbonato posto atrás delas. Uma vez escondido o dispositivo, o efeito pode ser lido como natural. Foi então fundamental encontrar meios para tensionar os filtros na face externa do prédio, trabalhando com profissionais de circo treinados para escalada e rapel. Eles usaram 
o equipamento que os permitia deslocarem-se ao longo das parede suspensos por cabos.
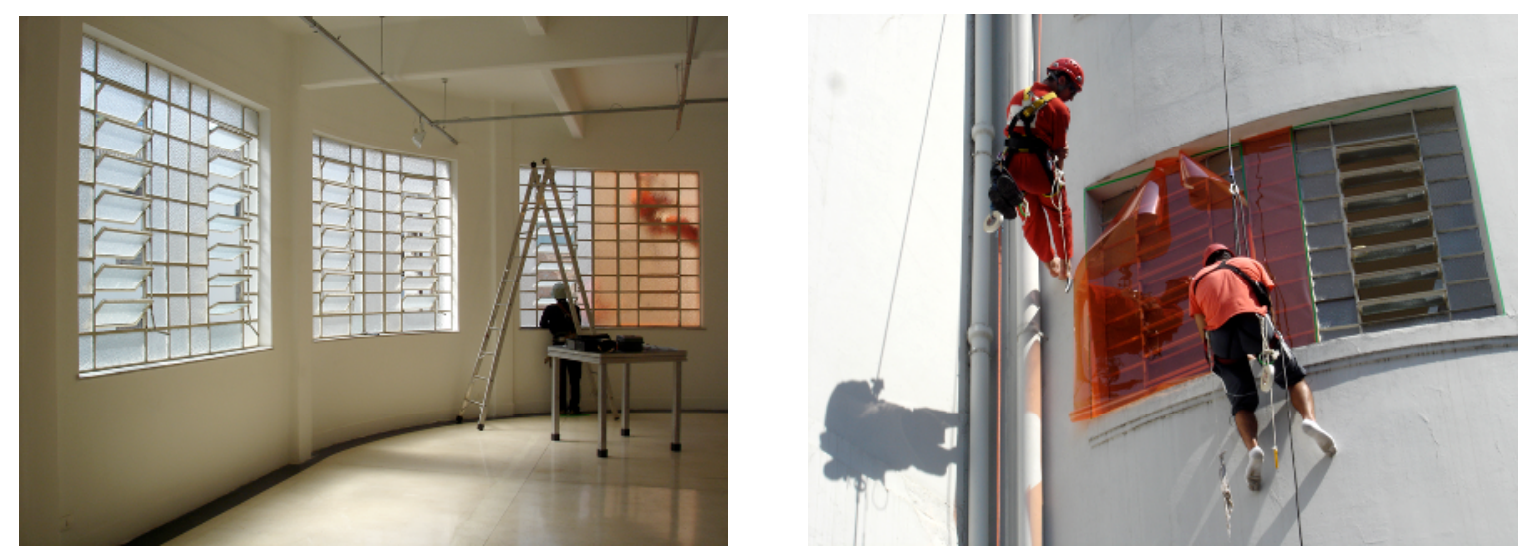

A transformação iniciava na escada de acesso aos espaços expositivos, do primeiro ao terceiro piso, todas as janelas com filtros compostos, densidade neutra misturados com correção para $3200^{\circ} \mathrm{k}$, diferentes graus de transparência (estas informações sobre o material são precisas e acompanham os mostruários).

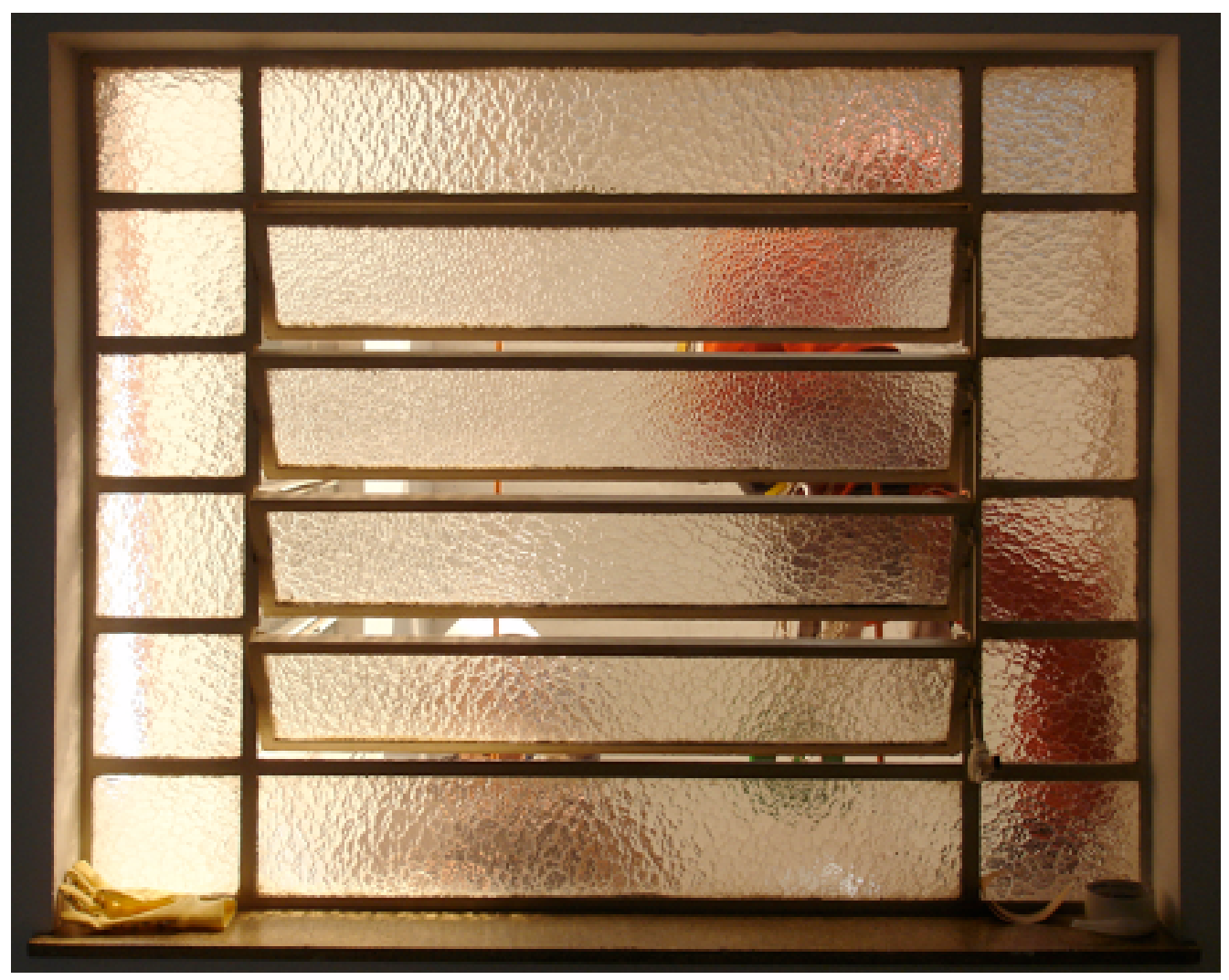



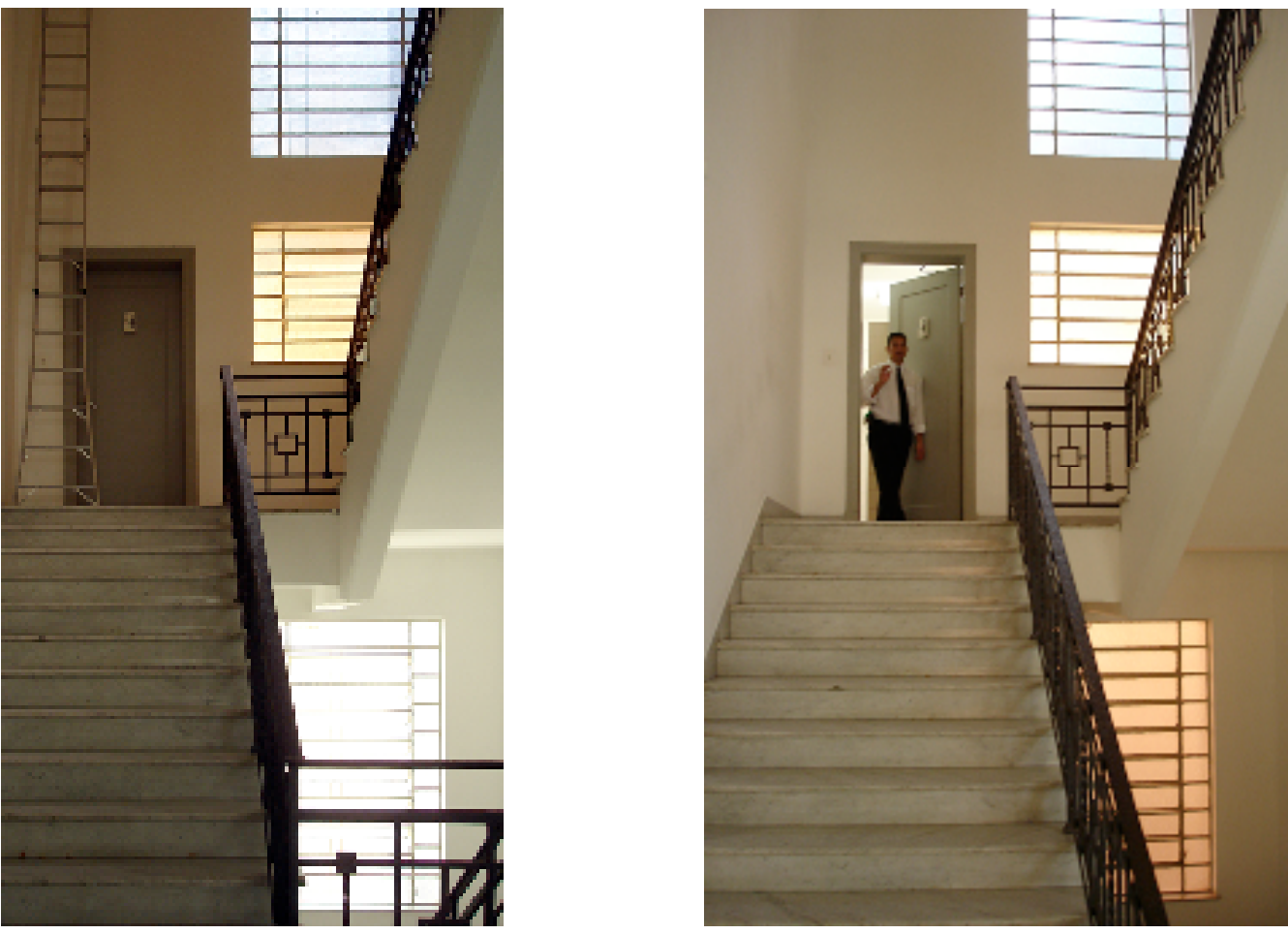

instalação das Correções de Luz em processo na área das escadas

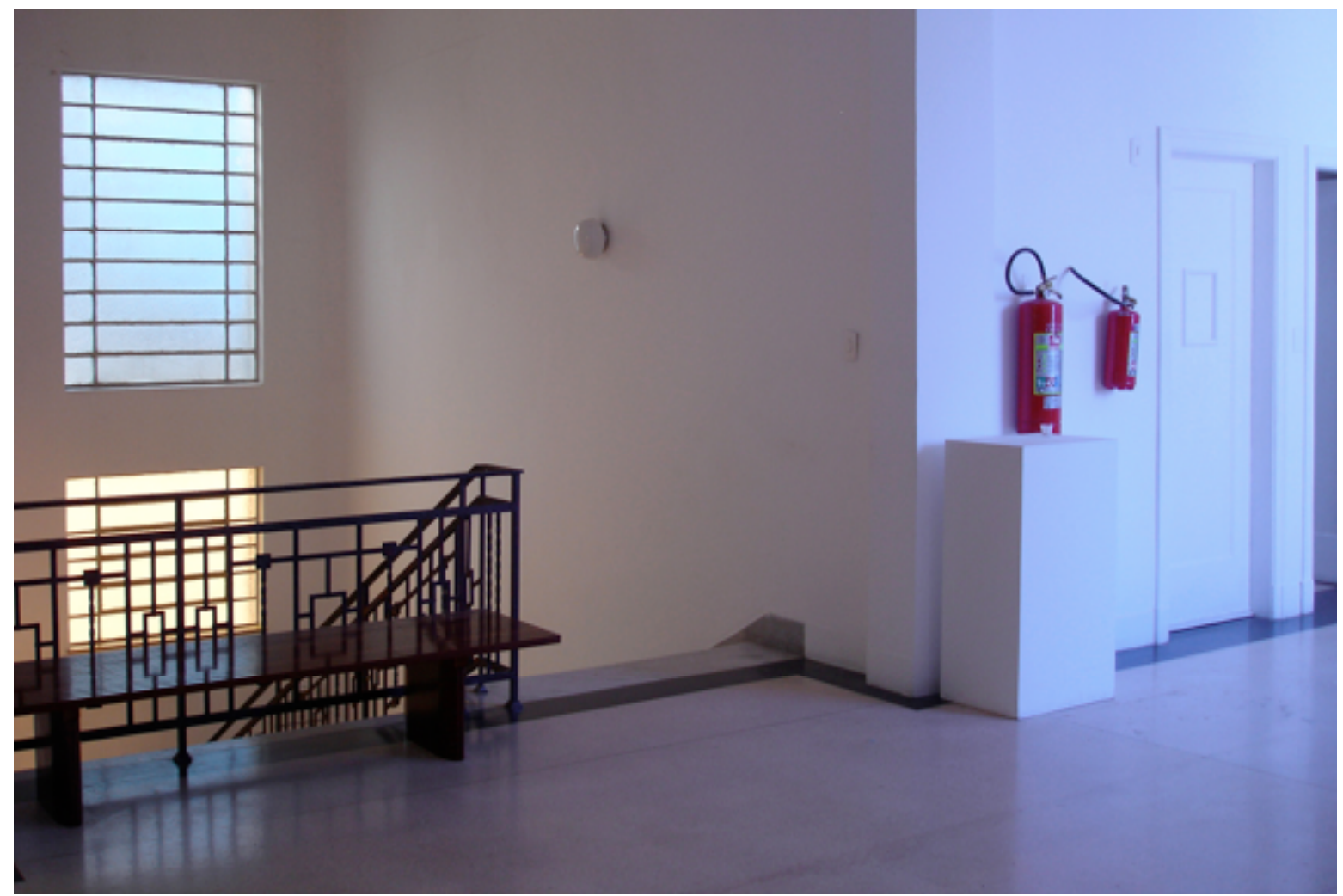

escadas e hall do segundo piso (filtro pale lavender) 

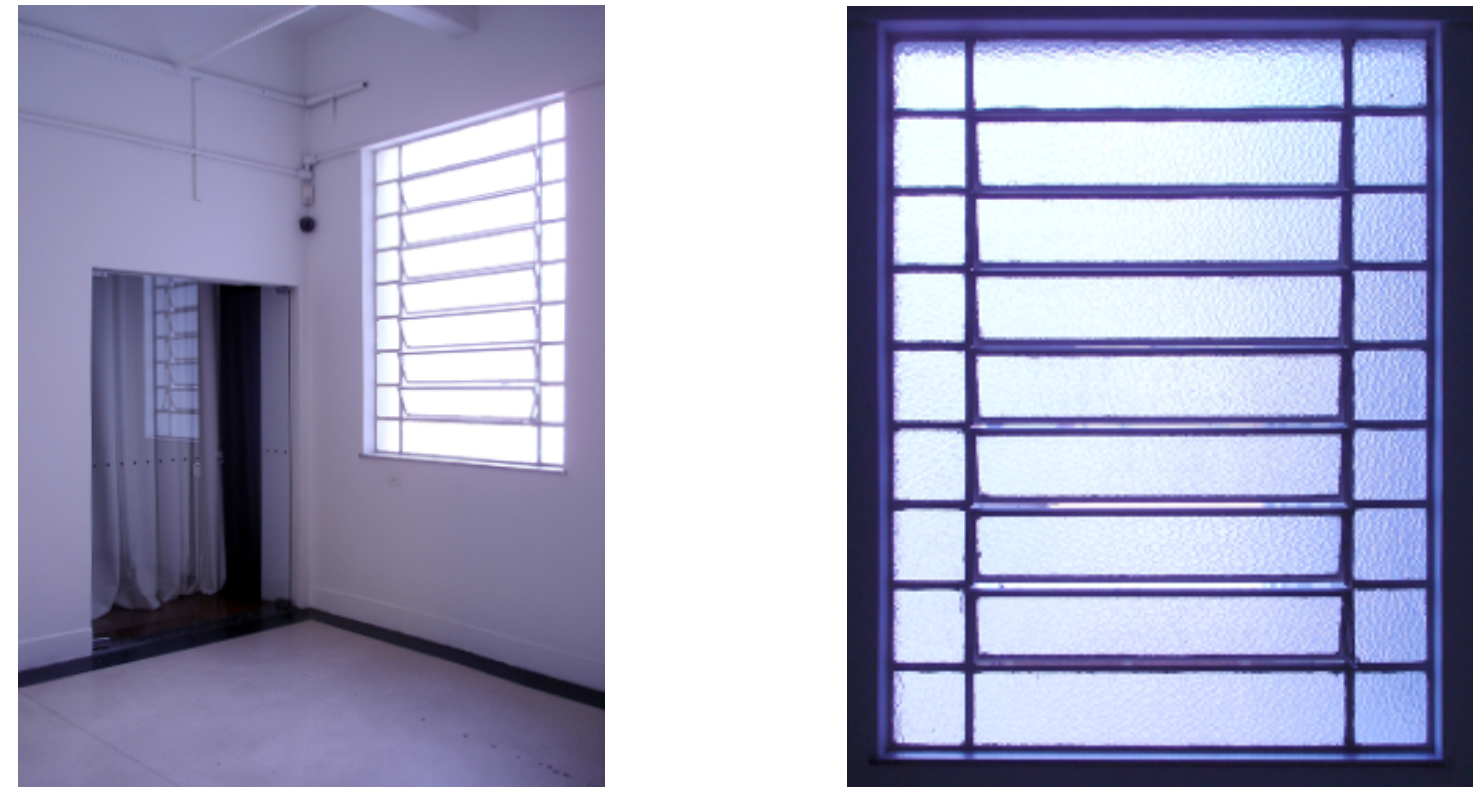

O filtro violeta que afetava a iluminação do hall do segundo piso, criava uma ante-câmara ativada no espaço que dava acesso a três salas de exposição. Foi colocado na janela junto a entrada da sala de Rochelle Costi, que tinha sua sala escurecida para a projeção de slides de seu trabalho "Uma festa". Cor meio noturna, atmosfera preparada. Na escada de acesso aos pisos de serviço foi colocado também um filtro na pequena janela, que era visível desde o hall e iluminava a passagem dos funcionários que frequentavam os escritórios.
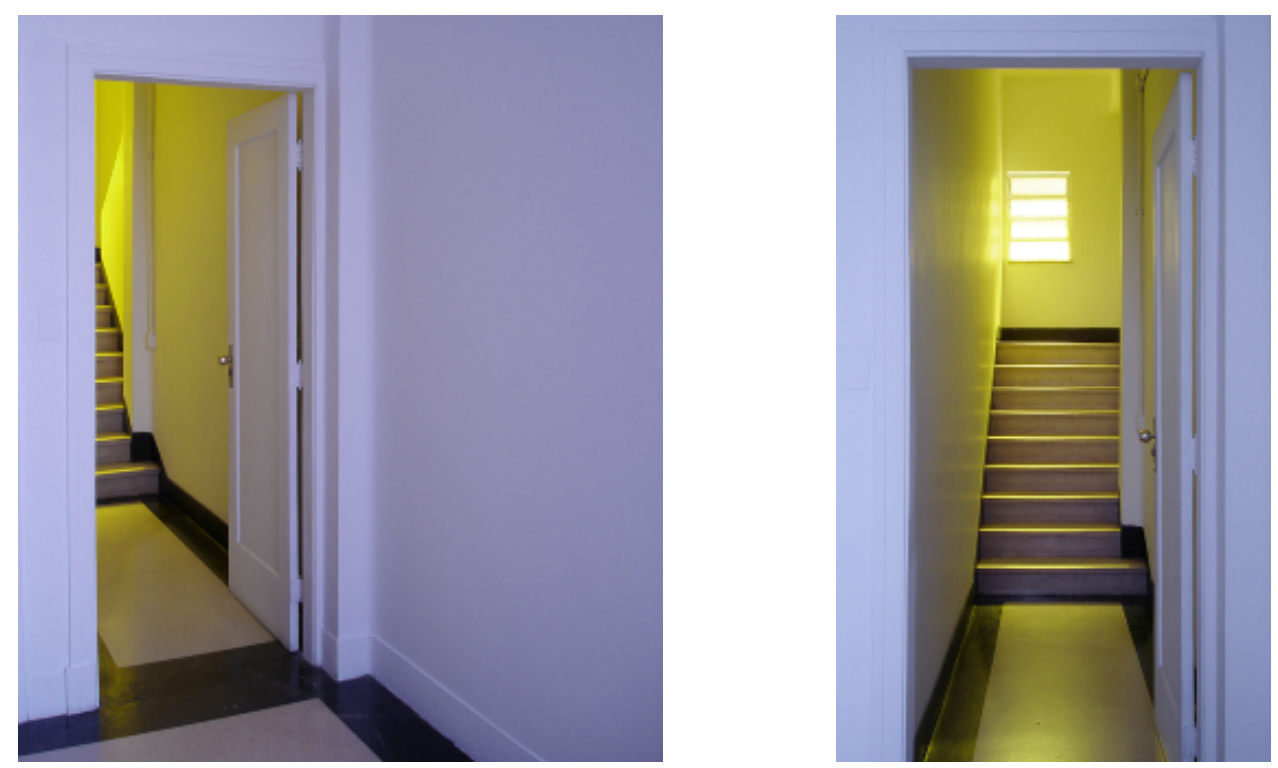
$\mathrm{Na}$ intervenção feita na Falkhalen, sala principal do Konstmuseum onde instalei as Light Corrections, havia uma seqüência de filtros semelhante a que foi usada nas Correções de Luz no Mariantonia. $\mathrm{Na}$ sua primeira versão, cada uma das novas colorações da luz era plausivel, às vezes até percebida como natural. Todas elas juntas mostravam uma escala cromática com diferenças muito visíveis. Nos espaços do Mariantonia esta escala tinha suas cores separadas nos ambientes, era percebida na passagem de um a outro.

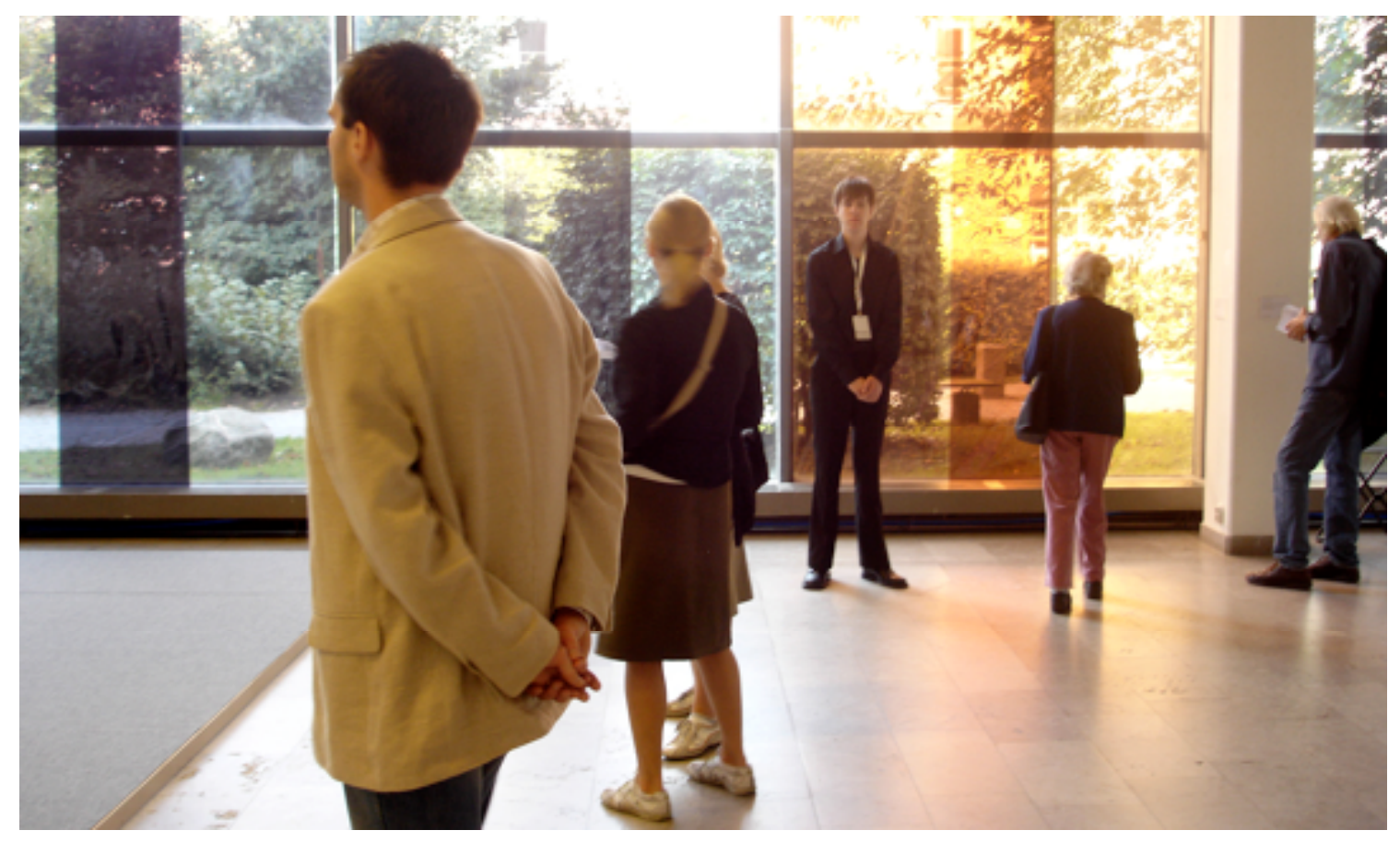

Quase todos os filtros foram reaproveitados da instalação Light Corrections montada em Göteborg dois anos antes. A gama de tonalidades, calibrada para correção de luz natural para artificial e vice-versa, a olho nu produz o efeito de diferentes horas do dia. O filtro que produziria a impressão de um espaço iluminado por lâmpada incandescente de tungstênio, acaba por criar a idéia de uma luz de final do dia, um poente com muitos nuances de vermelhos e laranjas. O filtro de densidade neutra menos transparente escurecia a atmosfera como uma tempestade. Esta escala usada nas primeiras correções de luz era portanto interessante para todas as seguintes. E deslocar um filtro para 
outra fonte de luz é um experimento que amplia o conhecimento do material e de suas possibilidades.

Transportando-os do outono sueco para a primavera e verão paulistas pude experimentar ainda outras variações bastante sensíveis. Ainda que sejam artifícios tecnicamente muito sofisticados, quando operamos com a luz do sol, estamos no campo de uma instabilidade natural, do sempre diferente.

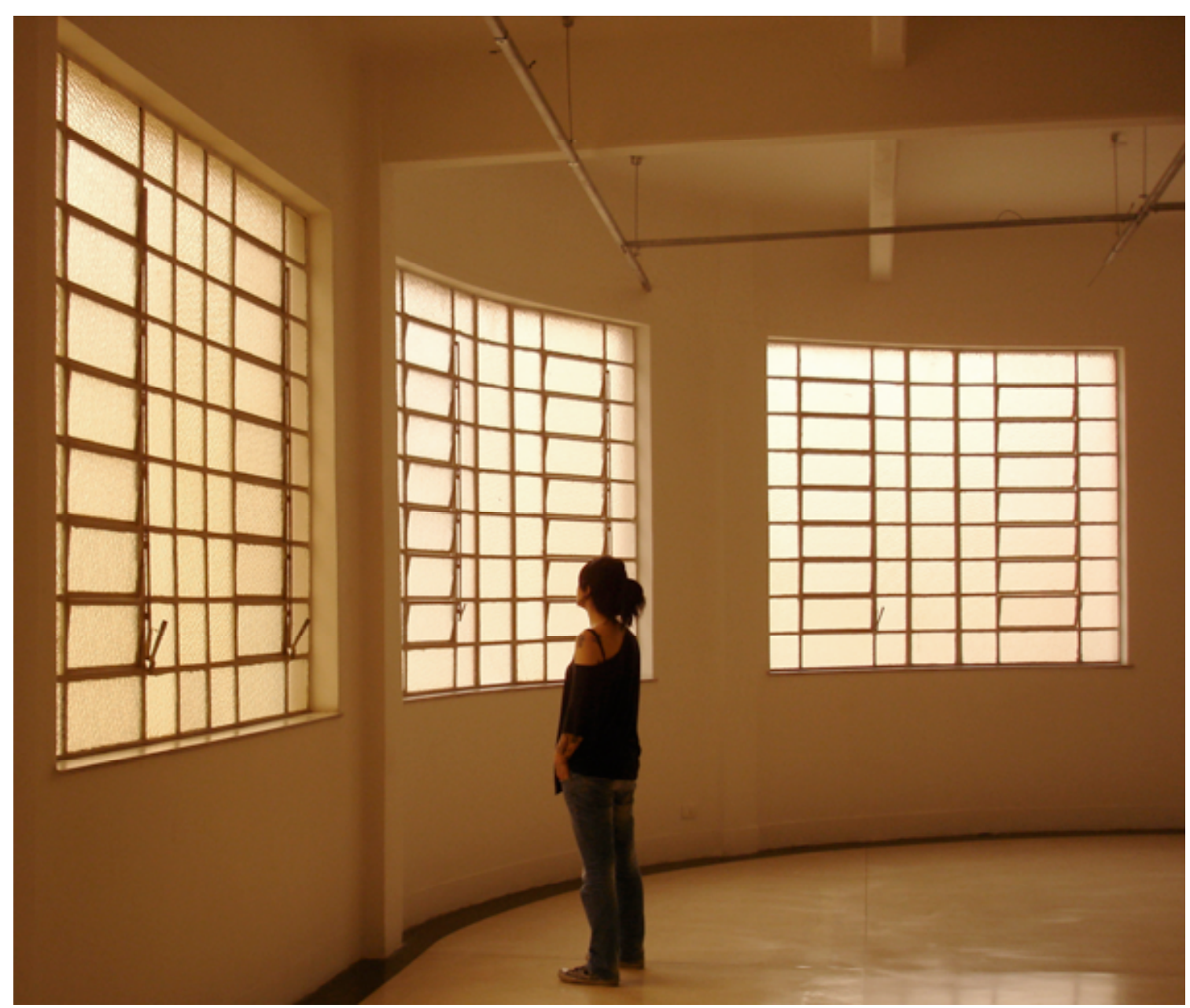

Sem objetos que funcionassem como anteparos refletindo a luz, e com sua reverbaração nas paredes nuas da sala, o caráter puramente atmosférico do trabalho dava espaço para observarmos as variações de luz e suas correspondentes flutuações de ânimo. A variação dos estados alterados e de seus modos de afetar os visitantes - estes sim, anteparos refletindo e absorvendo a luz "mais-que-natural" projetada na sala - provocava "idéias-affecção" 
como primeira reação. Mas este tipo de idéia, como nos ensina Spinoza, é demasiado precária e "inadequada" para dar conta de toda a experiência. Com a permanência nos espaços e caminhando de uma para outra luz, outros pensamentos mais especulativos apareciam acerca dos dispositivos e efeitos criados: porque éramos afetados positiva ou negativamente? Qual luz era mais natural? O que é natural? Quando me adapto a uma determinada luz, quando ela muda de cor ou temperatura, deixa de ser natural?

Uma experiência que tem sua duração dividida em etapas organiza pensamento de diferentes tipos, dá tempo ao sujeito de não apenas reagir quando é afetado mas também experimentar várias hipóteses, colocar questões, compreender os efeitos em termos não apenas de suas causas mas de suas repercussões. 


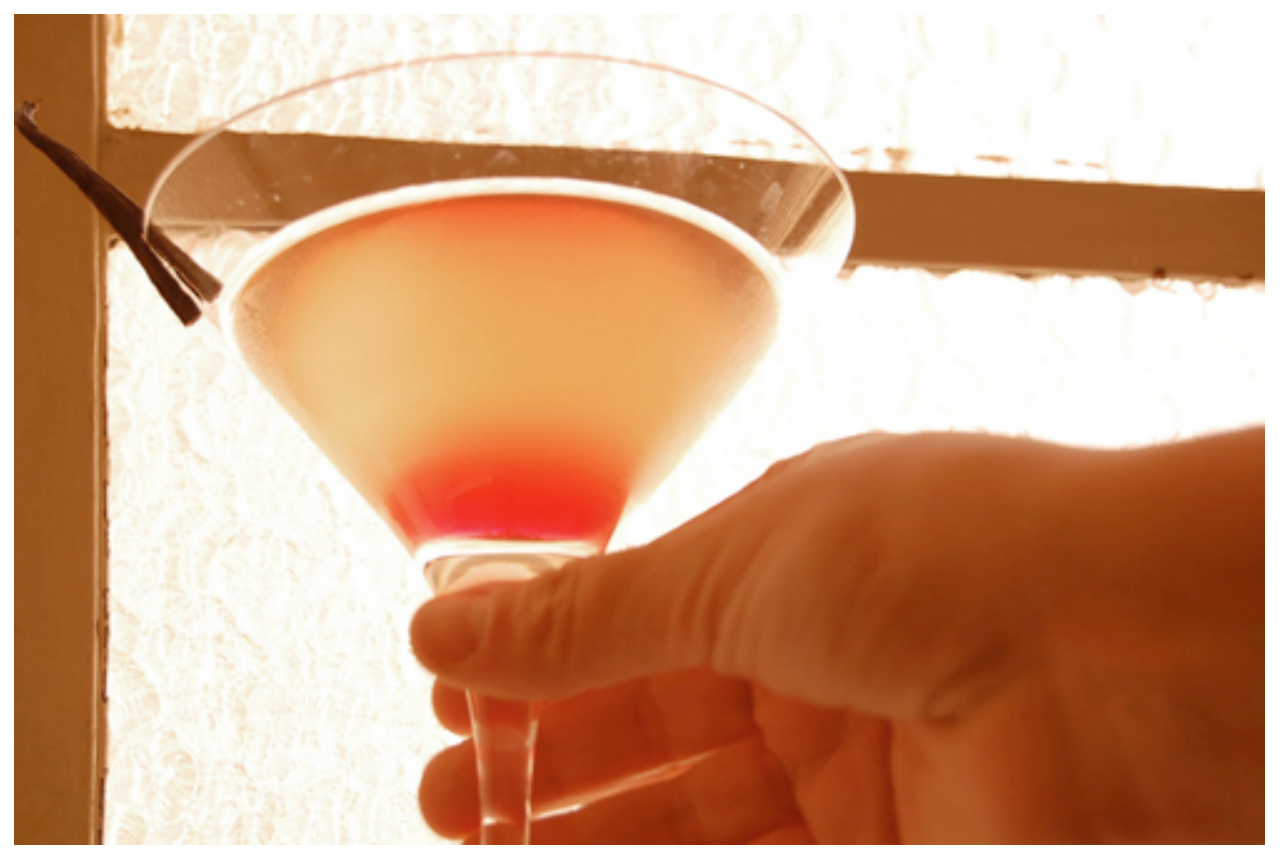

Filtro , 2007 -vodka; cardamomo; damiana; rosas; baunilha

O dispositivo filtro é a chave para toda a experiência, reflexiva ou não, com o conjunto de trabalhos apresentados aqui. Uma superfície transparente ou translúcida que colocada em janelas ou lâmpadas afeta as condicões de luz de um local; um dispositivo que opera sobre o espaço preparando-o com seus efeitos, para variados usos e ações.

Filtro era a palavra que os gregos usavam para designar uma poção ou elixir, bebidas enfeitiçadas que aparecem em muitas narrativas das culturas ocidentais. São misturas de substâncias para induzir estados alterados, fabricadas com ingredientes e procedimentos que conjuram os poderes mágicos desejados: lovendric, o "filtro do amor" bebido por engano, na lenda celta de Tristão e Isolda, faz com que eles se apaixonem instantâneamente, inevitavelmente.

Os coquetéis ou aperitivos, são também misturas de bebidas, usualmente servidos antes de uma refeição porque limpam as papilas gustativas e preparam para os sabores a experimentar. 
Em todo coquetel há uma bebida de base, quase sempre alcoólica e seca (spirit), que limpa as papilas e acende a percepcão dos sabores. Os efeitos anestésico e estimulante do álcool são combinados a outros ingredientes: o agente modificador dilui, mas revela o sabor da base e dá caráter próprio a mistura, e o acréscimo do agente especial é um desvio mínimo, que diferencia cada coquetel com cor ou aroma inesperados.

Para a exposição Correções de Cor, no Centro Universitário Mariantônia, criei um coquetel chamado Filtro, também proposto como indutor de alterações na percepção, com o uso de substâncias estimulantes. Um artifício para produzir no sujeito um estado alterado sintonizado com aquele provocado no próprio lugar.

Além da pesquisa de substâncias e misturas, e alguma leitura específica sobre coquetéis ${ }^{27}$, foi realizado um encontro para degustação. Todo processo teve caráter experimental e muito pouco científico. Os convidados experimentaram simultâneamente os efeitos dos filtros físicos na luz ambiente e o drinque a base de vodka que misturava damiana, rosas, cárdamomo e baunilha.

O Filtro expõe aquele que o bebe aos efeitos estimulantes destas substâncias largamente usadas em sociedades nas quais são reconhecidas como poderosos afrodisíacos. A baunilha e a damiana são cultivadas há muitos séculos no México. A baunilha tem propriedades excitantes enquanto damiana é empregada como relaxante. Pode-se também fumar a damiana, que tem efeito psicoativo semelhante ao da marijuana e é usada principalmente por mulheres, pois é reguladora dos hormônios femininos. O cardamomo é uma erva aromática que aumenta o fluxo sanguíneo, as rosas são usadas pra despertar afetos com seu perfume desde a antiguidade, sempre associadas ao simbolismo do amor. 

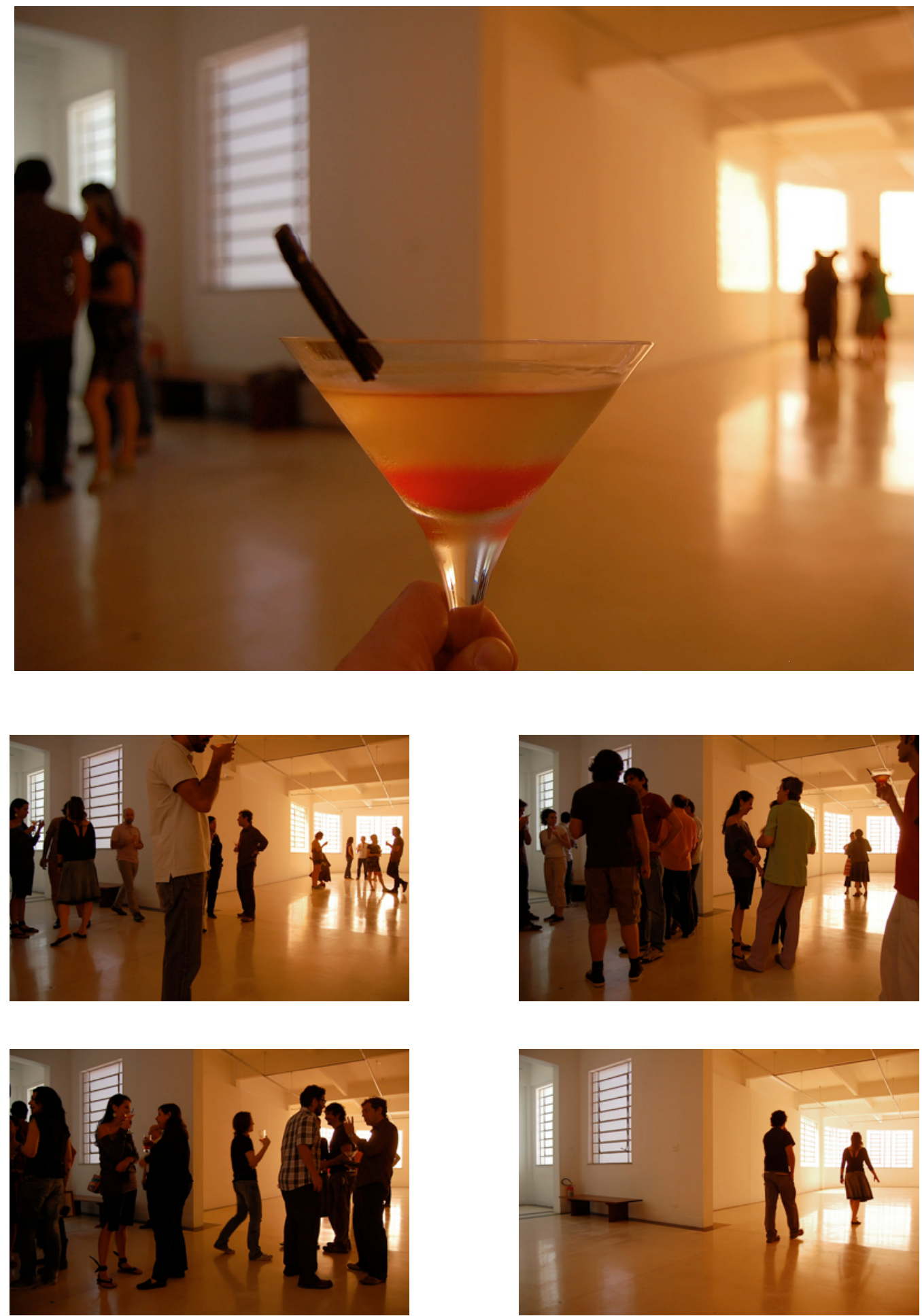

"Filtro" e "Correções de luz", Centro Universitário Mariantonia, São Paulo, setembro de 2007 
O coquetel Filtro deve ser montado e não agitado ou batido, para manter a transparência e as camadas distintas que proporcionam uma experiência em várias etapas:

1.aproximação : a fava de baunilha cortada e posta na borda da taça (de Dry Martini) é o último elemento acrescentado ao drinque antes de servi-lo, mas o primeiro a ser experimentado ao beber. Antes mesmo de beber. A nuvem de aroma de baunilha é percebida antes dos sabores, ainda expectativa.

2. entorpecimento: Os primeiros goles nos fazem esquecer o que esperamos sentir. A vodka diluída em muito gelo e temperada com sementes de cardamomo é a primeira camada e também a que age mais rápido, mais alcóolica. A base do drinque.

3. excitação : o licor de damiana é o sabor menos conhecido, ao menos do público brasileiro. Embora seja uma erva encontrada no Brasil e usada em infusões para diversos fins, os efeitos afrodisíacos da damiana são mais populares no México, onde se produz este licor que tem o seu nome. O licor de Damiana é o agente modificador. É possível fazer uma versão mais artesanal do drinque usando a infusão da erva na ausência do licor. O sabor da damiana será neste caso mais amargo e acentuado. Esta camada é densa e dourada.

4. o final que se extende: quando chegamos ao fundo, o xarope de rosas, tão doce quanto vermelho. É mais viscoso ainda que o licor na camada anterior, agente especial que desacelera o beber pois seu sabor difícil causa resistência. É preciso desejar os efeitos do "Filtro" para beber seu conteúdo até o final. 


\section{ACENDER O LUGAR}

Concluo mostrando dois dos trabalhos mais recentes, insistindo que é na minha produção que as questões são formuladas e as construções, mesmo conceituais, se efetuam. Pesquisa e Tese construídas com a ação e na dimensão da experiência. Casa Acesa e Conjunto A são projetos onde as proposições, como respostas a uma situação encontrada, tem nitidamente uma dimensão crítica que considera as relações estabelecidas no espaço, e é anterior a ação no lugar. A "potência de agir" diretamente proporcional ao "poder de ser afetado".

Casa Acesa foi pensado para La Casa Encendida, espaço cultural e social criado em Madrid para atender principalmente aos moradores do bairro de Lavapiés, povoado de imigrantes paquistaneses, africanos, chineses e latino-americanos - muitos deles em situação ilegal e a grande maioria trabalhado em subempregos. Este contexto é portanto uma zona de grande tensão social que demanda um espaço de perfil multicultural e que ofereça uma estrutura de serviços e equipamento acessível, aberta, como se propôs ser La Casa Encendida. O discurso que apresenta o lugar se estrutura em quatro eixos: cultura, solidariedade, meio ambiente e educação.

Minha primeira visita a La Casa $^{28}$ foi o encontro com um prédio de arquitetura imponente (originalmente abrigava cofres de uma instituição bancária, que hoje financia o espaço), salas de trabalho bem equipadas e parcialmente ocupadas, corredores vazios, terraço visitado por grupos de estudantes ou trabalhadores em horário de almoço. Apesar da intensa e interessante programação oferecida, o fluxo diário de pessoas

\footnotetext{
${ }^{28}$ Vou chamar assim a La Casa Encendida, pelo nome que usam seus frequentadores.
} 
não parecia ocupar de fato o espaço da vibração necessária a idéia de uma casa em chamas ou acesa como sugeria seu nome.
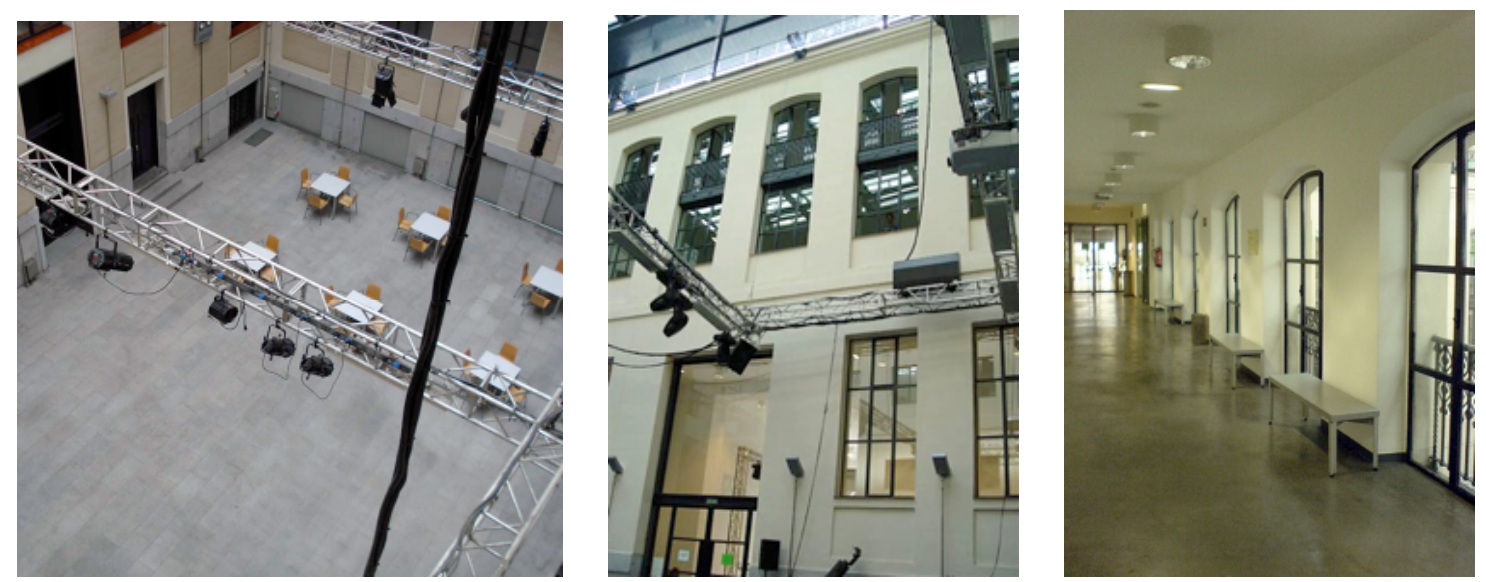

Seu núcleo é um pátio coberto que recebe concertos e montagens teatrais, muitas vezes fechado a público, com paredes de granito muito altas e entrada de luz natural. A caixa de vidro cobrindo sua área total me pareceu a chave para acender La Casa, já que a luz do sol entrando ali percorria o pátio ao longo do dia e atravessava também as janelas internas, iluminando assim todos os corredores e áreas de circulação. A cubierta (clarabóia) do pátio foi o lugar da primeira intervenção pensada para Casa Acesa.

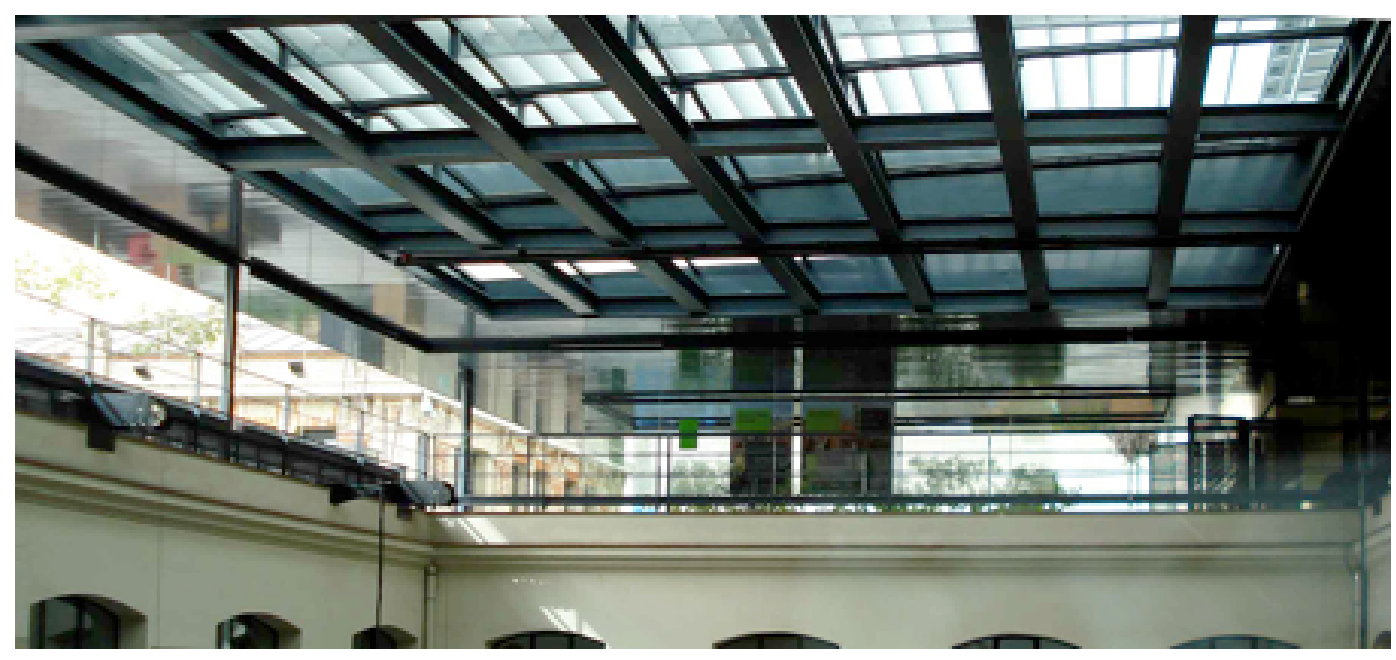

Imagem da cubierta de vidro en La Casa, vista desde uma janela do ultimo piso. Além de abertura e entrada de luz, a clarabóia era um elemento visível de quase todos os espaços de circulação. 


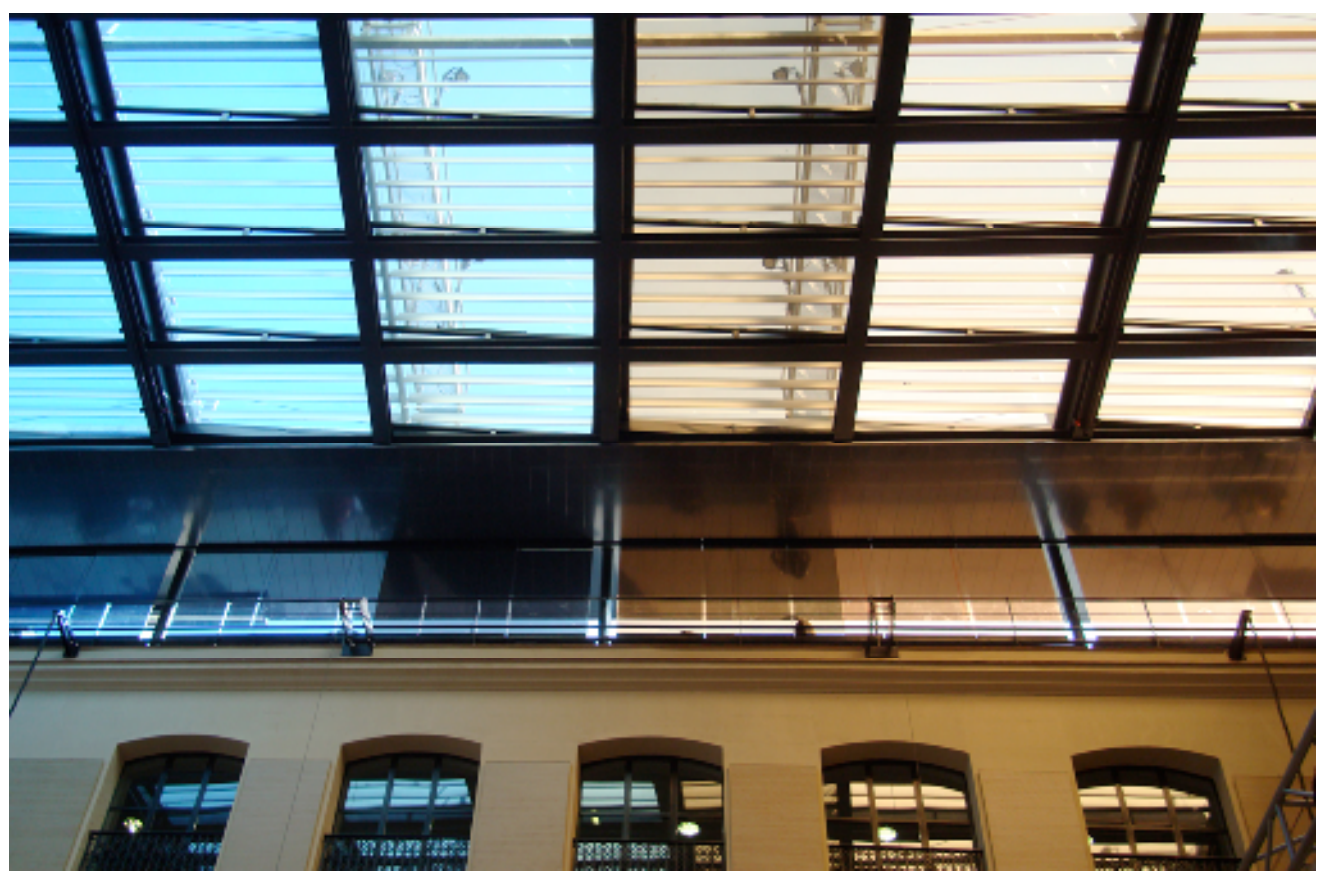

"Casa Acesa", 2008. Filtros de correção de cor para cinema.

Foram usados ali os mesmos filtros de correção de cor para cinema já apresentados antes, num gradiente de tonalidades complementares que produzia no centro do espaço uma luz quase branca, mas que vibrava naquele núcleo que era o Pátio. O movimento da luz do sol projetada no espaço de certa forma acompanhava a sequência de cores dos filtros.
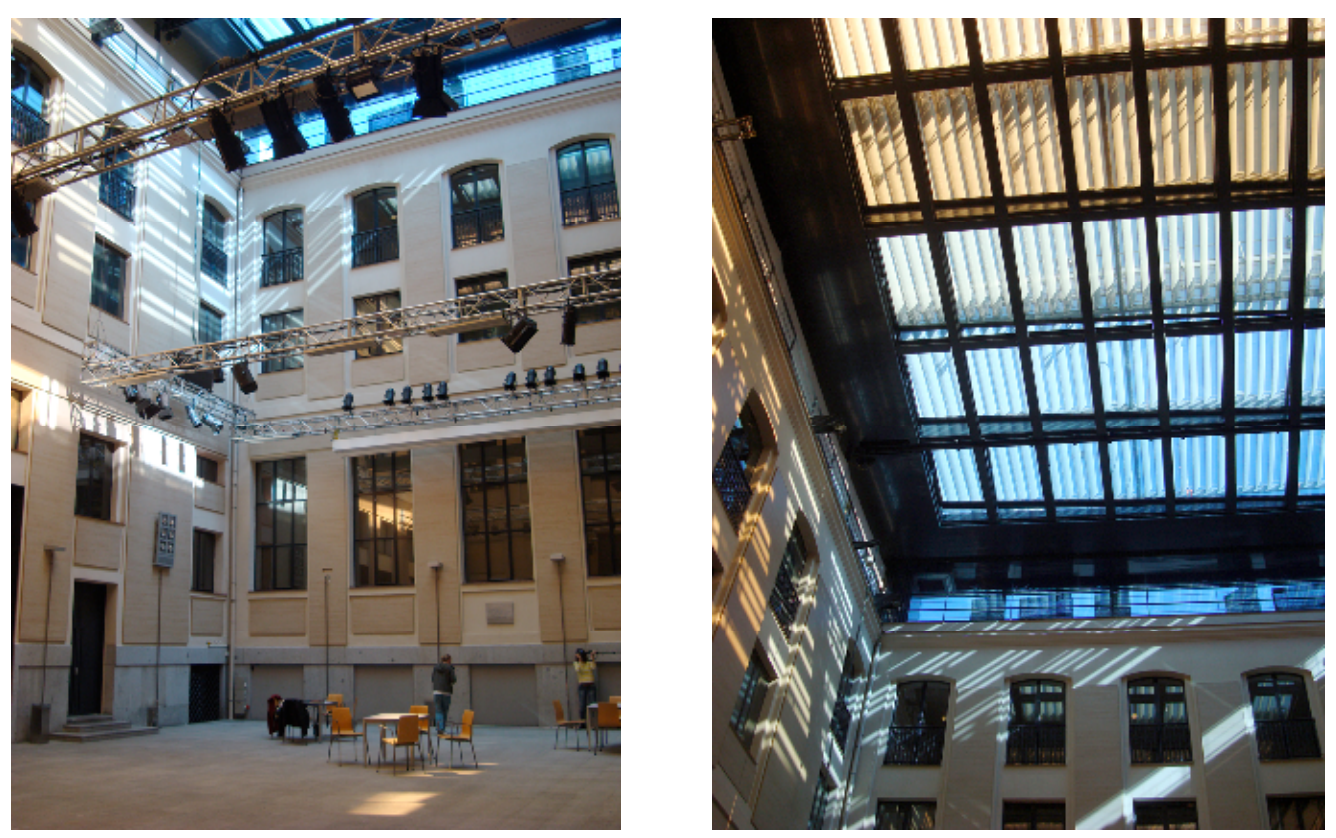


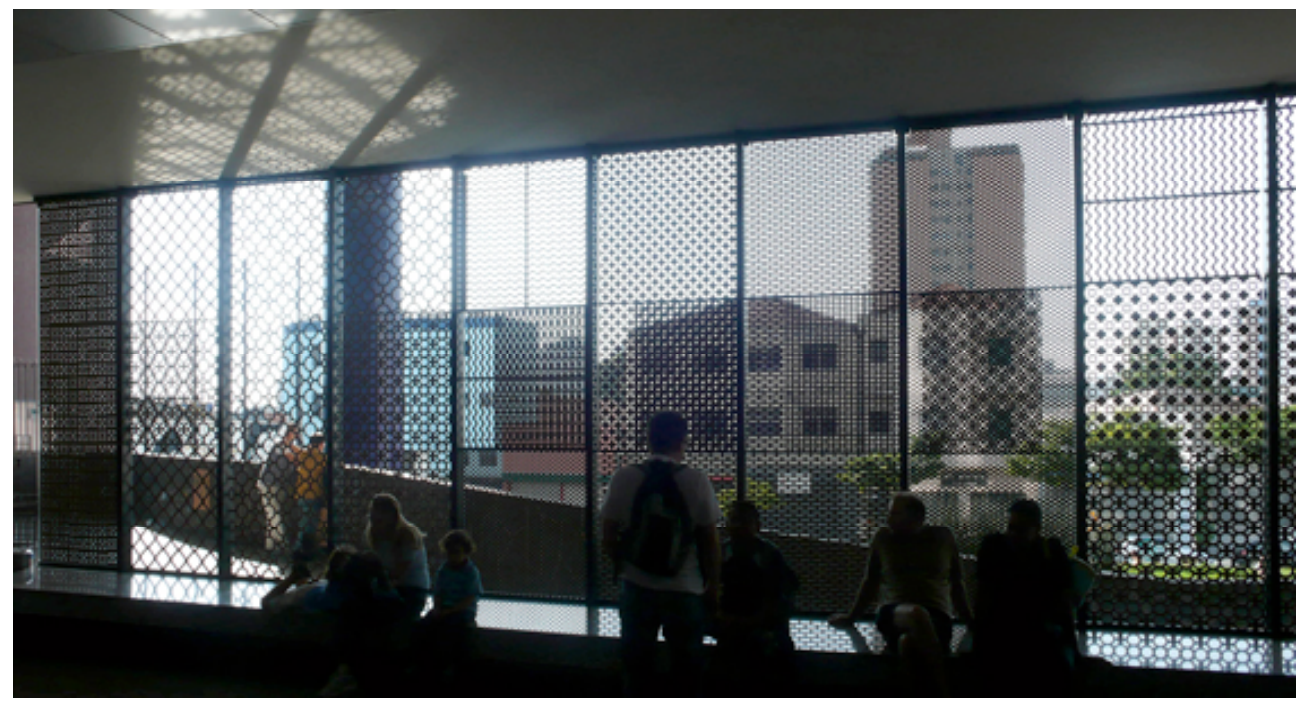

"Conjunto A", 2008. Chapas de MDF recortadas a laser, 3 x18 mts

Aprofundando a pesquisa com padrões recortados, derivados de cobogós, está Conjunto A, um dos conjuntos possíveis que está definido neste trabalho por extensão, pela apresentação simultânea de seus elementos. Este conjunto foi criado para uma exposição no SESC Pinheiros, unidade construída para atender a população do distrito de Pinheiros em São Paulo, e mais especificamente os frequentadores - comerciários ou não - da Rua Paes Leme e seus arredores. No entanto seu prédio se implantou neste terreno sem parecer considerar a escala das construções existentes no entorno, prédios de no máximo dois andares, pequenas lojas. Suas dimensões excessivas neste contexto se devem provavelmente a necessidade de abrigar os equipamentos e serviços culturais, médicos, e sociais que as unidades do SESC oferecem, mas acabam se impondo na paisagem de modo ostensivo, quase ameaçador. Materiais empregados, como aço, vidro e granito, nada tem a ver com os materiais e ferramentas de marcenaria que circulam diariamente no comércio local. $O$ projeto arquitetônico desta unidade a destaca do entorno não apenas na escala, mas recuando literalmente da calçada e recebendo o visitante com uma fachada de vidro mais refletiva que transparente, pouco permeável. 


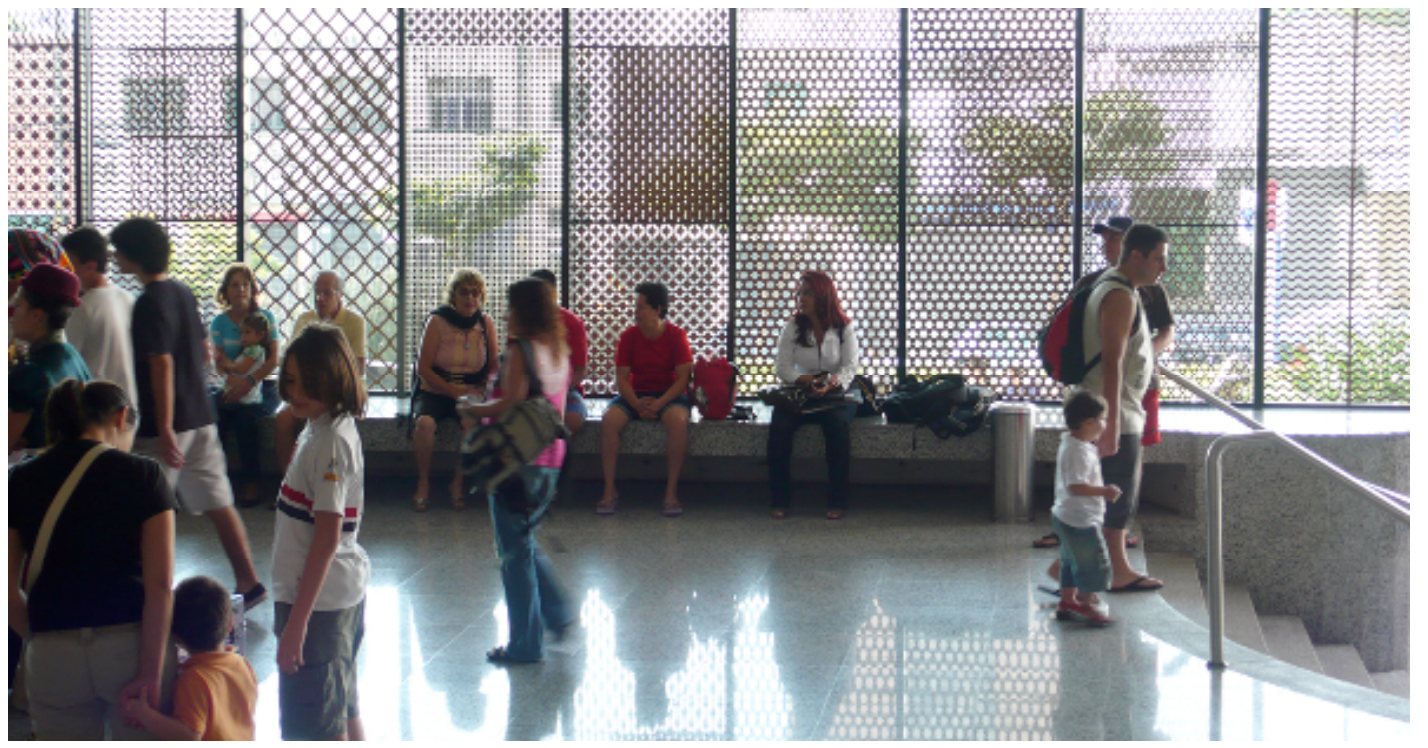

A primeira escolha do projeto para intervenção no SESC foi sua localização no prédio: a parede de vidro da fachada interna, no piso térreo. Elemento circundado de espaços de circulação e lugar de pausa, com o grande "banco" construído na base desta "parede", em toda sua extensão. E a segunda escolha, usar uma variedade de padrões recortados em MDF, material familiar ao entorno, que posto ali seria visível não apenas para os visitantes do SESC, mas também para aqueles passando pela rua, desavisados. Assim, por reconhecimento, conectar também os não-usuários a algo acontecendo ali.

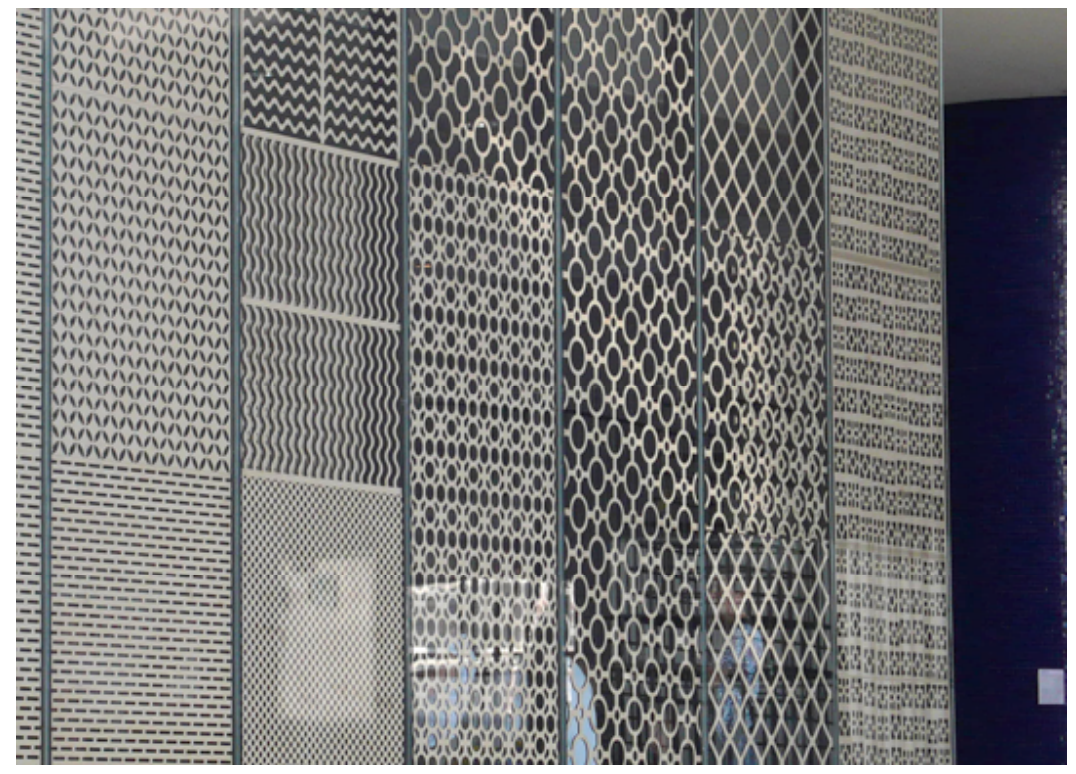

detalhe da vista externa de Conjunto A 
A variação dos padrões era posta na grade ortogonal adaptada da parede original, à maneira de uma estrutura combinatória, como em muitos trabalhos anteriores. A equivalência das partes no todo, do ponto de vista formal, favorece a continuidade da superfície e sua transparência. A proximidade com as lojas de madeira, laminados e MDF, e esta estrutura como de classificação, faziam com que Conjunto A fosse visto como um grande mostruário de material. Isto trouxe para o trabalho um público que buscava saber mais deste "novo material": "onde se pode comprar?"; "quanto custa o metro?"; "tem em que espessuras?". Ou especulava outras combinações em outros lugares: "este padrão lá em casa, dividindo a cozinha e a sala...".

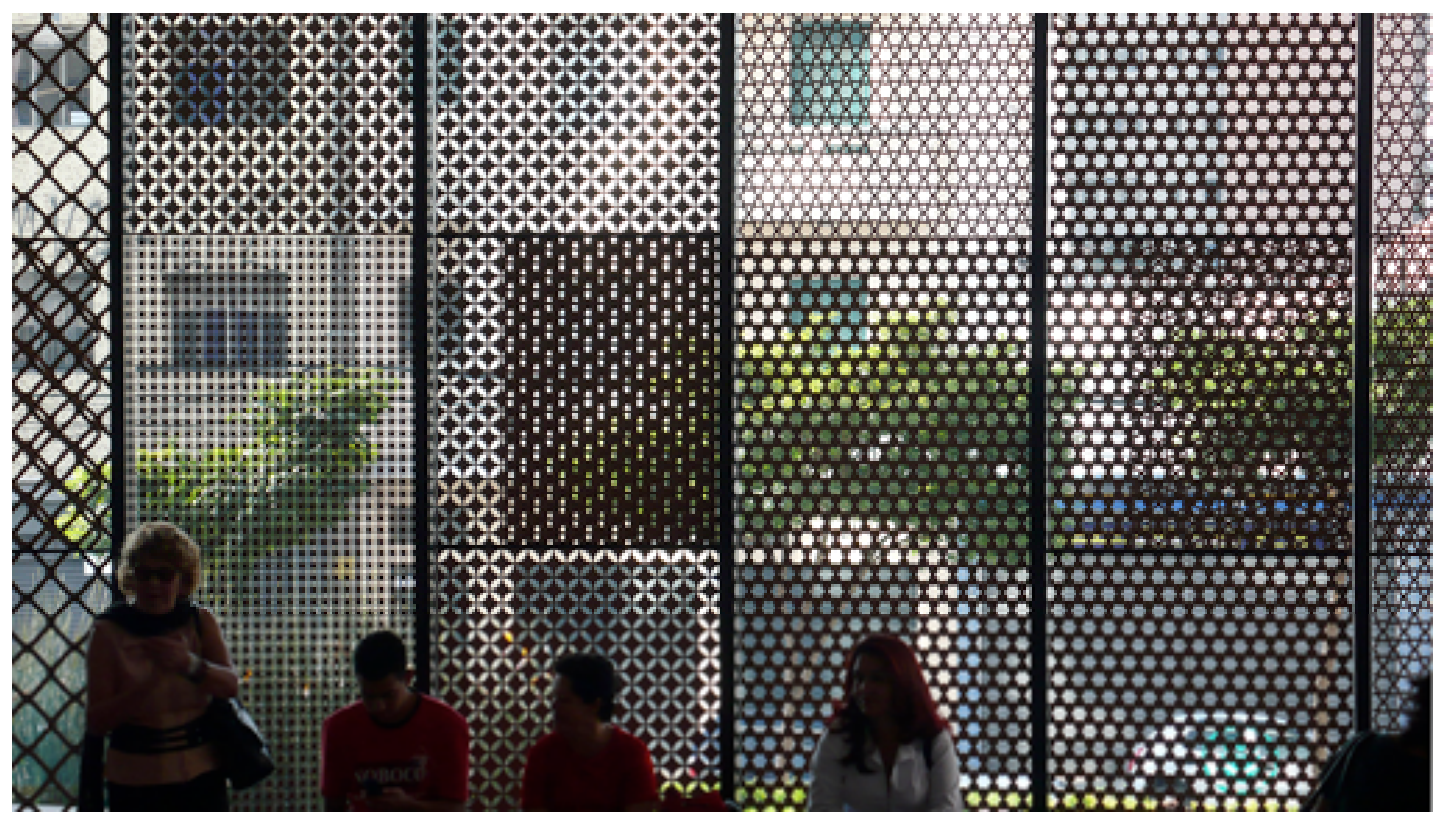

vista interna de Conjunto A (dia)

Além das placas justapostas e coladas ao vidro, havia trilhos onde corria uma outra camada de módulos deslizantes. A sobreposição destas peças criava outros padrões, e podia ser experimentada pelos visitantes. Assim se acrescentava movimento e variação constante, os padrões se (de)formando diante dos olhos dispositivo exposto que mesmo assim não anulava seu efeito. A sobreposição de camadas em movimento, como recurso para 
multiplicação de padrões, já havia aparecido em trabalhos anteriores, como Dein Spiegel ou Vedação (imagens em anexo >).

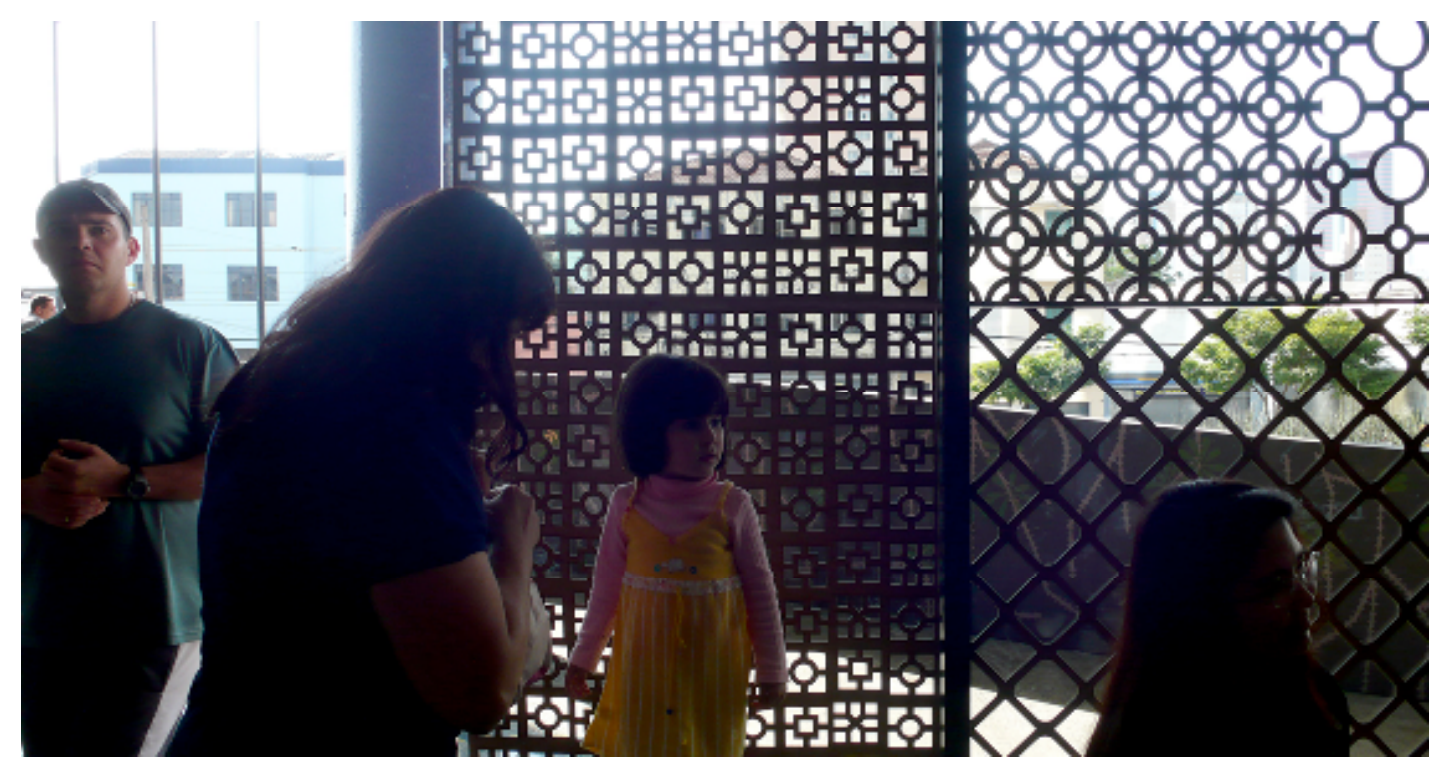

Para operar sobre o trabalho, e consequentemente no lugar, o visitante assume-se como algo mais que observador. Na medida em que é afetado pelo trabalho, especula suas razões e dispositivos, observa e deduz modos de funcionamento, experimenta ele mesmo agir. Mas tudo isso pode acontecer também num nível menos consciente, quando ele naturalmente muda a forma de ocupar o lugar alterado, ou pensa sobre ele mesmo sem perceber o dispositivo instalado ali.
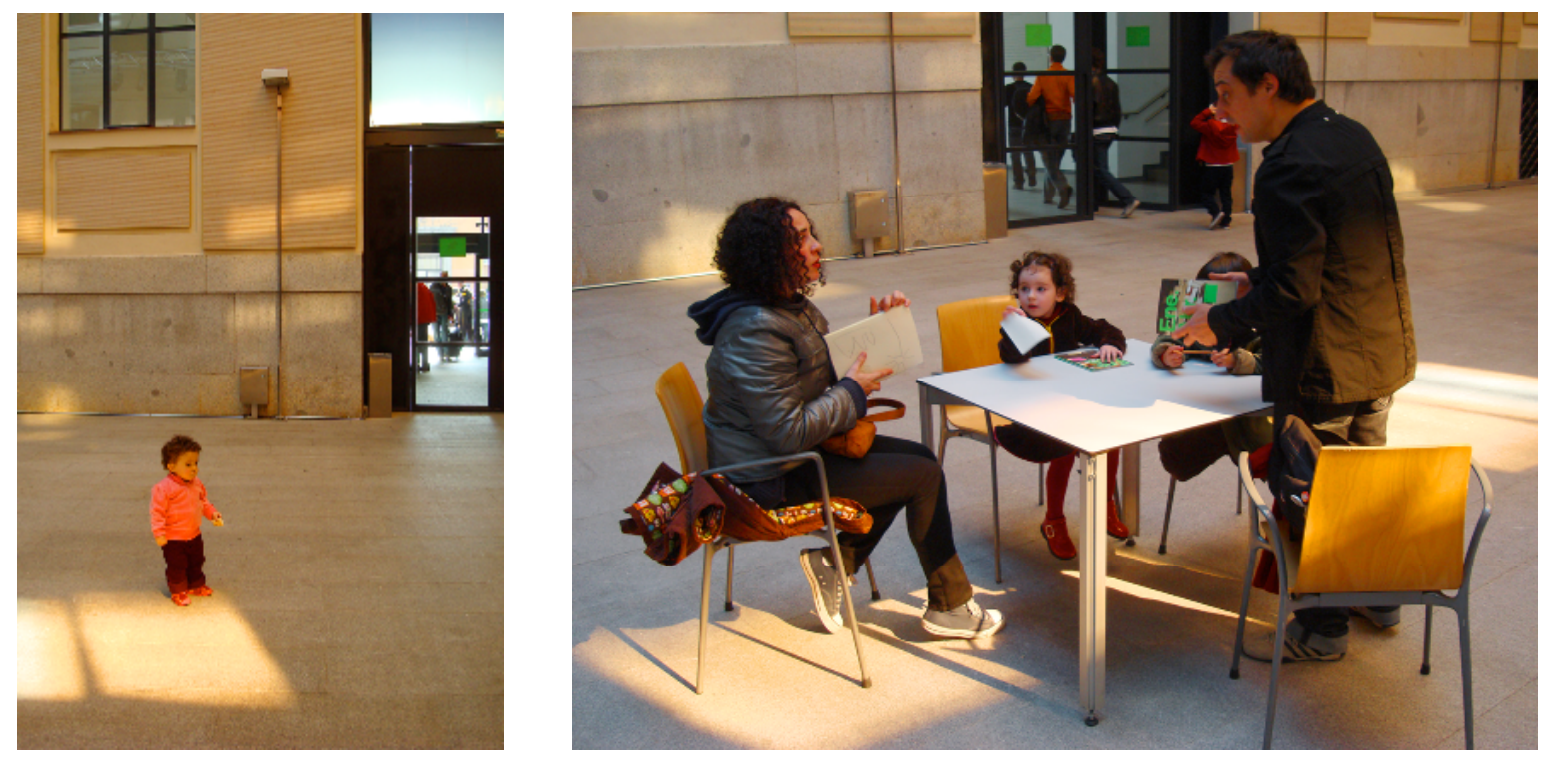


\section{CONCLUSÃo}

A opção por observar a repercussão dos trabalhos, na experiência do sujeito que visita o lugar em estado alterado, acaba desviando a atenção do acontecimento que define toda a ação efetuada ali: antes de tudo, o lugar afeta a mim. E afeta os outros que habitualmente o frequentam. Os afetos e idéias que mobilizam minha ação num lugar são gerados por minha experiência nele. Por isso é natural que quando convidada a realizar projetos desta natureza, me convidem também a visitar o lugar antes de conceber minha intervenção. Isto é necessário não apenas pelos aspectos objetivos a observar para viabilizar a produção, pois estes poderiam ser informados a distância, através dos muitos meios para a comunicação com imagens, plantas, textos. O que é essencial é conhecer o lugar e experimentar sua luz ambiente, pensar seu contexto, conversar com seus frequentadores, entender os sentidos já efetuados e os outros tantos possíveis nele.

Os textos mais teóricos registram a vontade de compreender os principais conceitos operando no trabalho, como transformações miméticas, ser afetado/afetar, arte ambientada, filtro como dispositivo de comunicação. O uso da linguagem lógico-matemática, e do universo da arquitetura, são inevitáveis porque é por via destes que o pensamento e a ação se organizam nestes trabalhos.

O resposta do público indica um estado alterado bem ou mal recebido, uma mistura de corpos que pode ser mais ou menos estimuladora da ação. As alterações na dinâmica do espaço, integradas por mimetismo ao lugar, e portanto com um certo grau de realidade, são justamente o que os trabalhos apresentados nesta tese querem produzir. As táticas usadas a cada trabalho são respostas ao embate com um local específico, onde se define não apenas como agir mas se projeta o sentido da ação. Embora não haja controle total sobre seus efeitos, os estados alterados são provocados intencionalmente. 


\section{BIBLIOGRAFIA}

BARTHES, Roland. O Neutro. São Paulo: Martins Fontes, 2003.

BENJAMIN, W. Sobre la facultad mimética. In: Ângelus Novus. Barcelona: Edhasa, p. 167-170., 1971

BUREN, Daniel. textos e entrevistas escolhidos (1967-2000), org. Paulo Sergio Duarte, Rio de Janeiro: Centro de Arte Helio Oiticica, 2001

CAILLOIS, Roger. Mimetismo e Psicastenia legendária. Revista CHE VOUI, ano1, $\mathrm{n}^{\circ}$ 0, 1986, p. 49-73.

CERTEAU, Michel de. A Invenção do Cotidiano - 1: Artes de Fazer. Petrópolis: Ed. Vozes, 1994.

COSTA, Lucio. Arquitetura. São Paulo: José Olympio Editora, 2002.

COUTINHO, Evaldo. O Espaço da Arquitetura. São Paulo: Ed. Perspectiva, 1998.

FOSTER, Hal (editor). Vision and Visuality. Discussions in contemporary culture. Seattle: Bay Press, 1988

FOUCAULT, Michel. As Palavras e as coisas: uma arqueologia das ciências humanas. $6^{a}$ ed. São Paulo: Martins Fontes, 1992

GAGNEBIN, J-M. Sobre a questão da mimesis. In: Sete aulas sobre linguagem, memória e história. Rio de Janeiro: Imago Ed., 1997.

GOMBRICH, E. H., The Sense of Order - a study in the psychology of decorative art. London: Phaidon Limited, 1979.

GRAHAM Dan, et al. Two-Way Mirror Power: Selected Writings by Dan Grahan on His Art.

KWON, Miwon. One place after another: notes on site specificity.In: October 80, pp. 85-110. Massachusetts: MIT Press, 1997.

LACAN, Jacques. "O estádio do espelho como formador da função do eu". In: Escritos. Rio de Janeiro: Jorge Zahar, 1998.

LÉVY, Pierre. O que é virtual? Trad. Paulo Neves. São Paulo: Editora Martins Fontes, 1996.

MARINS, Paulo Cézar Garcez. Através da Rotula Sociedade e Arquitetura Urbana no Brasil, séculos XVII a XX. São Paulo: Humanitas FFLCH-USP, 2001.

NESBITT, Kate (org.). Uma nova agenda para a arquitetura: antologia teórica (19651995). São Paulo: COSACNAIFY, 2006.

NOBRE, Ana Luiza , KAMITA, João M.,LEONIDIO, Otávio e CONDURU, Roberto (orgs.) Um Modo de Ser Moderno - Lucio Costa e a crítica contemporânea. São Paulo: Cosac \& Naify, 2004. 
O'DOHERTY, Brian. No interior do Cubo Branco - A ideologia do Espaço da Arte. São Paulo: Martins Fontes, 2002.

PAIM, Gilberto. A beleza sob suspeita - o ornamento em Ruskin, Lloyd Wright, Loos, Lê Corbusier e outros. Rio de Janeiro: Jorge Zahar Editor, 2000.

ROWE, Colin. "Transparency: Literal and Phenomenal." In Architecture Culture 1943-1968, A Documentary Anthology. Joan Ockman, editor. New York: Rizzoli, 1993.

SANTOS, Milton. A Natureza do Espaço. São Paulo: Edusp, 2002.

SHEIKH, Simon. In the Place of the Public Sphere?. Berlin: editora b_books, 2005.

SPINOZA, Benedictus de. Ética. Belo Horizonte: Ed. Autêntica, 2008. (Edição bilíngue: latim/português)

STILES, Kristine e SELZ, Peter (org.). Theories and documents of contemporary Art: A sourcebook of artists Writings. Los Angeles: Univ. Of Calif. Press, 1996.

TURNER, John F. C.. Housing by people Towards Autonomy in Building Enviroments. London: Great Britain, 1991.

VIDLER, Anthony. The Architectural Uncanny: Essays in the Modern Unhomely. Massachusetts: MIT Press, 1992.

Massachusetts: MIT Press, 2000.

Warped Space: Art, Architecture and Anxiety in Modern Culture. (org.) Histories of the immediate present: inventing architectural modernism . Massachusetts: MIT Press, 2008.

VIRILIO, Paul. O Espaço Crítico. São Paulo: Editora 34, 1999.

WEIMER, Günter. Arquitetura popular brasielira. São Paulo: Martins Fontes, 2005.

ARANTES, Otília; ARANTES, Paulo Eduardo. Um ponto cego no projeto moderno de Jürgen Habermas. São Paulo, Brasiliense, 1992.

ARANTES, Otília. A arquitetura depois dos modernos. São Paulo, Edusp, 1995.

TSCHUMI, Bernard. Architecture and disjunction. Cambridge: MIT Press, 1996.

TANIZAKI, Junichirô. In praise of shadows. Londres: VINTAGE BOOKS, 2001. 